\title{
Berättelseskrivande i skolan \\ Att studera, beskriva och utveckla ett kunnande
}

\author{
Anja Thorsten
}

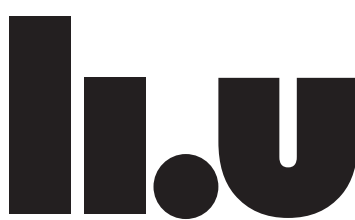

LINKÖPINGS UNIVERSITET

Linköping Studies in Behavioural Science No 208

Utbildningsvetenskap

Linköping 2018 
Linköping Studies in Behavioural Science • No. 208

Distribueras av:

Institutionen för beteendevetenskap och lärande Linköpings Universitet

58183 Linköping

Anja Thorsten

Berättelseskrivande i skolan

Att studera, beskriva och utveckla ett kunnande

Upplaga 1:1

ISBN 978-91-7685-258-3

ISSN 1654-2029

(C)Anja Thorsten

Institutionen för beteendevetenskap och lärande 2018

Tryckeri: LiU-Tryck, Linköping 2018 


\section{SAMMANFATTNING}

Syftet med avhandlingen är att bidra med kunskap om hur kunnandet att skriva berättelser kan bli undervisningsbart. Detta belyses ur två infallsvinklar, svenskdidaktiskt och metodologiskt. Avhandlingens empiriska underlag består av elevintervjuer, filmade lektioner, elevtexter, fältanteckningar, mötesprotokoll och reflektionsanteckningar som samlades in under genomförandet av en Learning study om berättelseskrivande i årskurs 3 och 4. I en Learning study undersöker en forskargrupp, med forskande lärare, iterativt hur undervisningen kan läggas upp för att eleverna ska utveckla ett avsett kunnande.

Med hjälp av narratologi, fenomenografi och variationsteori analyserades elevers kunnande, elevers lärande och undervisningen. Resultatet visar att när kunnandet att skriva berättelser ska göras undervisningsbart, behöver eleverna få möjlighet att urskilja (a) vad ett läsarperspektiv innebär samt (b) hur berättelsers struktur kan byggas upp med problem och lösning. Dessa båda aspekter specificeras i några andra aspekter, till exempel det utrymme olika delar i berättelsen får samt övergångarna mellan berättelsens ingående delar. I den här avhandlingen analyseras också hur lärares erfarenhetsbaserade kunskap samverkar med variationsteori $i$ en Learning study, med utgångspunkt i Polanyis begrepp tyst kunskap och teoretiska resonemang om hur erfarenhet påverkar hantering, tolkning och bedömning av yrkesspecifika situationer. Resultatet visar att när lärares erfarenhet och variationsteorin kombineras i en iterativ modell finns förutsättningar för en kunskapsgenererande forskningsprocess. Lärarnas erfarenhetsbaserade kunskap påverkar valet av forskningsområde och gör att fokus riktas mot relevanta delar i analysprocessen. Variationsteorin bidrar med teoretiska redskap i analysen och leder till att lärandeobjektets innebörd och synliggörande är i fokus i hela processen. 


\section{ABSTRACT}

The purpose of this thesis is to add knowledge about how the knowing of storywriting can be made teachable. This question will be addressed from two points of view: a subject-knowledge perspective and a methodological perspective. The data consists of student interviews, student stories, video-recorded lessons, field notes, meeting minutes and reflective notes collected during a Learning Study about story-writing with 9- and 10-year-old students. In a Learning Study a research group, made up of teacher researchers, investigated iteratively how the teaching can help students to develop a particular knowing. Students' knowing, students' learning and the instruction was analyzed using narratology, phenomenography and Variation Theory. The results show that in order to make the knowing of storywriting teachable, students need to be able to discern two main aspects: (a) seeing the story from the reader's perspective and (b) discerning that a story is built up by problems and solutions. These two aspects consist of some other aspects, such as duration and connections between different parts of the story. The methodological issue is addressed by analyzing how teachers' practice-based knowledge interacts with Variation Theory in a Learning Study. Polanyi's concept of "tacit knowledge" and other theoretical concepts of practice-based knowledge were used in the analysis. The results show that combining teachers' experiences and Variation Theory in an iterative research model creates good conditions for a knowledge-generating process. Teachers' practice-based knowledge affects the choice of research questions, and puts the focus on relevant parts of the data. Variation Theory brings theoretical tools to the analysis, and ensures there is a focus on the object of learning throughout the process. 


\section{AVHANDLINGENS PUBLIKATIONER}

Avhandlingen är baserad på följande publikationer, som refereras till i romerska numreringar.

I Thorsten, A. (2014). Perspektiv och problemlösning $i$ berättelseskrivande. Vad elever behöver lära sig och hur det kan synliggöras $i$ undervisningen. (Licentiatuppsats). Jönköping: Högskolan för lärande och kommunikation.

II Thorsten, A. (accepterad). How to compose a narrative - students' approaches and pedagogical implications. Writing and Pedagogy, publiceras hösten 2018.

III Thorsten, A. (2015). How teachers' practice knowledge is used and challenged in a Learning Study using Variation Theory as a tool. International Journal of Lesson and Learning Studies, 4(3), 274-287.

VI Thorsten, A. (2017). Generating knowledge in a Learning Study from the perspective of a teacher researcher. Educational Action Research, 25(1), 140-154. 



\section{FÖRORD}

Att skriva en berättelse är ett kunnande som innebär urskiljande av en mängd olika aspekter. Detsamma kan sägas om att skriva en avhandling. Den här avhandlingen har vuxit fram med hjälp och stöd av en mängd olika personer, texter och sammanhang. På så sätt har jag fått möjlighet att lära, utvecklas och erfara nya aspekter, vilket har gjort det möjligt att skriva denna avhandling. Allting började 2012 när jag blev antagen till forskarskolan Learning study, i vilken jag skrev min licentiatuppsats. I den tackar jag flera personer som var viktiga i den processen. Även nu vill jag rikta ett extra tack till Ulla Runesson, som var min handledare då, och även till resten av forskarskolans ledning: Ingrid Carlgren, Inger Eriksson och Mona Holmqvist-Olander. Mycket av min kunskap vilar på det jag lärde mig av er. Det är ni som gett mig min grundläggande och ovärderliga skolning som praktiknära forskare.

Arbetet med andra delen av avhandlingen påbörjades 2015. Det var under den sista perioden jag skrev de tre artiklar som ingår. Tack till institutionen som genom Stefan Samuelssons forskningsfinansiering har möjliggjort denna avhandling. Mina båda handledare, Katarina Eriksson-Barajas och Eva Wennås-Brante, har genomgående stöttat mig i stort och smått. Katarina - tack för att du alltid bemött mig respektfullt och för att du har ifrågasatt och diskuterat det jag tagit som självklart. Tack också för ihärdigt tjatande om lyftet i diskussionen (och i andra delar) - det blev betydligt bättre. Eva - tack för ditt engagemang och för din snabba och genomarbetade respons. Du har fått mig att ta ett steg till i mina resonemang.

Under arbetets gång har jag också haft externa diskutanter. Maj Asplund Carlsson, vid $60 \%$-seminariet: Tack för inspiration till den sista artikeln. Tack också till Synnöve Martre för bra synpunkter på den sista artikeln när den började växa fram. Ingrid Carlgren, vid slutseminariet: Tack för att du hjälpte mig att ringa in avhandlingen och få den att hålla ihop. Tack också för alla givande och utmanade diskussioner under de senaste åren och tack för att jag fått njuta av ditt vackra sommarparadis. I slutfasen av mitt arbete fick jag värdefulla synpunkter som hjälpte till att ge avhandlingen dess slutliga form, tack för det Robert Thornberg och Joakim Samuelsson.

På Linköpings universitet finns många personer att tacka. Först vill jag rikta ett varmt tack till hela PeDi. Jag trivs mycket bra! Jag uppskattar alla skratt och alla intressanta samtal och diskussioner, ni är många som är speciella för mig, fler än jag kan nämna här. Cissi - att ha dig som rumsgranne, att få diskutera allt från variationsteori till vardagens betänkligheter, är en ynnest. Jocke - tack för att din fåtölj alltid är ledig. Svenskgruppen med Åsa, Magnus, Annika, Tina och Ulrika tack för bra samarbete. Sofia, tack för bra samarbete i kurser, skrivande och annat.

Jag vill också tacka några ur min "gamla" forskarskola och människor jag mött i samband med den. Ni har funnits kvar även på den fortsatta resan. Ett särskilt tack till Malin och Patrik: ni kommer alltid med kloka tankar, både som vänner 
och som kollegor. Tänk så många spännande projekt vi ska göra och vilka intressanta artiklar vi ska skriva! Jocke, Tuula, Jenny, Helene och Ulf - vad vore variationsteori utan er?

Jag vill också rikta ett extra varmt tack till alla lärare och elever som deltog $\mathrm{i}$ studien. Utan er hade inget av det här varit möjligt!

Tack till Staffan Thorström, för att du gjorde framsidan efter alla mina önskemål.

I skrivandet av en avhandling är det inte bara själva arbetet med analys, text m.m. som ska fungera. Även livet som helhet är avgörande för om det går att genomföra och slutföra ett avhandlingsarbete. Familj och vänner har varit ovärderliga på så sätt. Jag kan inte med ord uttrycka hur tacksam jag är över min fina familj. Tack mamma och Ove, Mathias och Katarina, Linda och Tobbe samt Mia och Fredrik och alla barnen. Ni har funnits där och ställt upp på ett sätt som är långt utöver vad man kan förvänta sig. Tusen tack! Sara, Sanna och Tove - tack för allt! Tack också till Malin Olsson, Mia Mårtensson, Maria Lerm, Lisa Kilman och Eva Jansson. Goda vänner betyder mycket! Jag vill också tacka tre personer som dansade in i mitt liv vid nyår. Tack Anna och Sirpa för vår nyfunna vänskap. Tack till dig fina Håkan, för att du delar glädje, torpmys, dans och mycket mer med mig!

Avslutningsvis vill jag tacka mina tre underbara barn Albin, Emilia och Edvin. Ni är fantastiska och får mig att komma ihåg vad som är viktigt i livet. 


\section{INNEHÅLLSFÖRTECKNING}

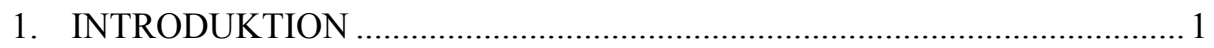

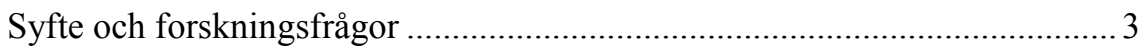

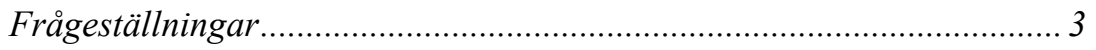

Avhandlingens disposition ..................................................................... 4

2. BERÄTTELSESKRIVANDE .................................................................. 5

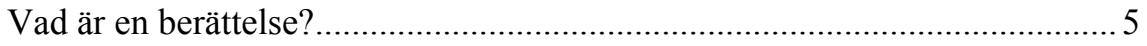

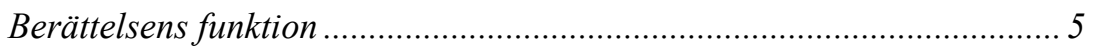

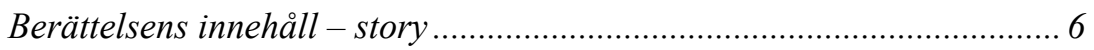

Berättelsens form - diskurs ............................................................... 7

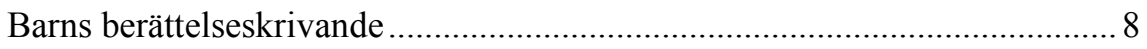

Hantering av den narrativa strukturen ................................................. 8

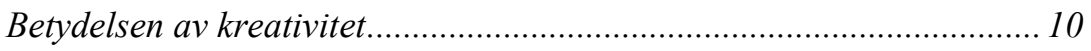

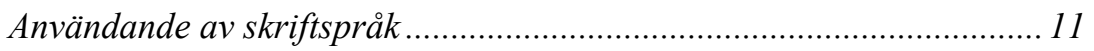

Skapande av struktur och sammanhang $i$ skriven text ........................... 12

Teoretiska perspektiv på skriftspråklig utveckling och förmåga ............ 13

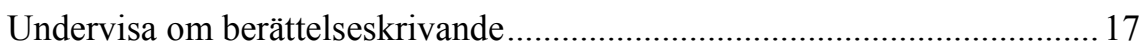

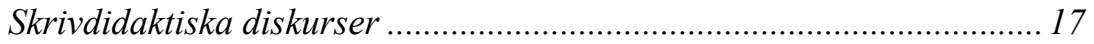

Explicit och implicit undervisning......................................................... 19

Att utveckla barns berättelseskrivande .......................................................... 21

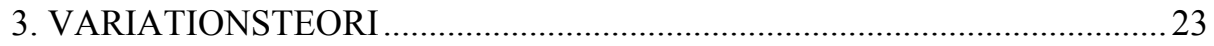

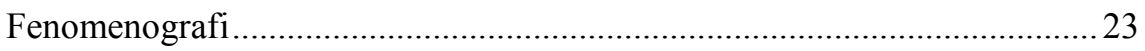

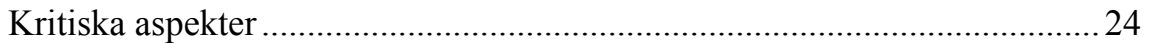

Variationsmönster - att synliggöra kritiska aspekter i undervisningen .........25

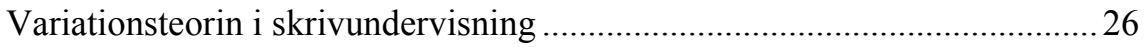

Variationsteorin i denna avhandling............................................................ 27

4. ATT UNDERSÖKA OCH UTVECKLA ETT KUNNANDE..........................2 28

Undervisningsutvecklande forskning .......................................................... 28

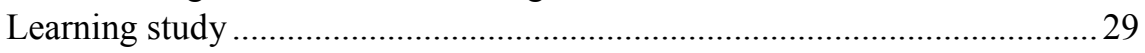

Learning study-processen...................................................................... 30 
Learning study som forskningsansats och skolutvecklingsmodell 31

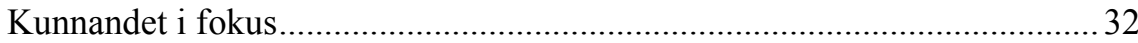

Ämnesdidaktisk kunskap - PCK ...................................................... 33

Lärarerfarenhetens betydelse i forskningsprocessen .................................. 34

Lärares erfarenhetsbaserade kunskap .............................................. 35

Forskningspraktik med forskande lärare ......................................... 36

Teoriers betydelse för kunskapsbidraget .................................................. 38

Teorier på olika nivåer ................................................................. 38

Teorins betydelse som analysredskap ............................................ 39

Genererande av ny teoretisk kunskap .............................................. 40

5. METOD OCH GENOMFÖRANDE .......................................................... 41

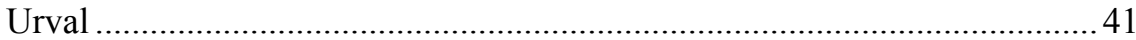

Etiska överväganden........................................................................... 42

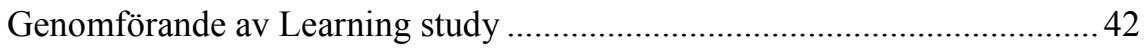

Kartläggning ................................................................................. 43

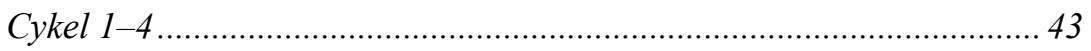

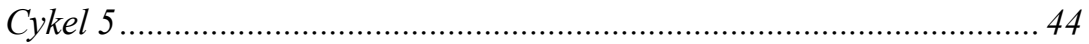

Empiriskt underlag ................................................................................. 44

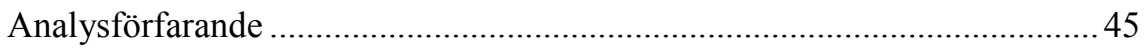

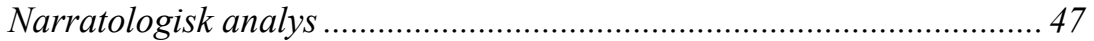

Fenomenografisk analys............................................................. 47

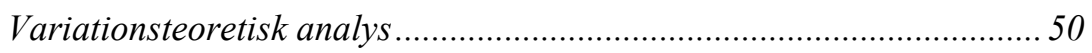

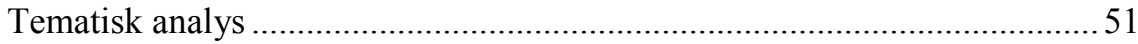

Induktiv tematisk analys ........................................................... 52

Teoretisk tematisk analys ........................................................... 52

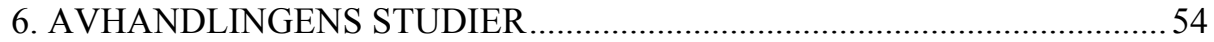

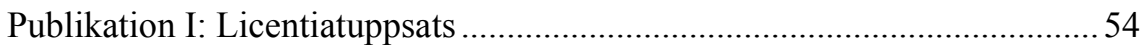

Publikation II: Artikel.......................................................................... 56

Publikation III: Artikel ............................................................................ 57

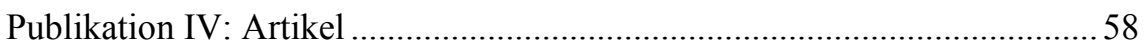

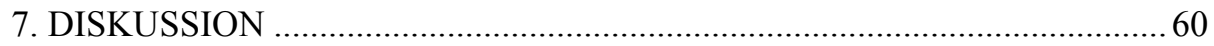

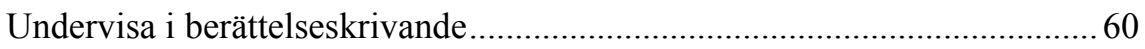

Möjliggöra erfarande av läsarperspektiv ......................................... 60 
Möjliggöra urskiljande av den narrativa strukturen........................... 62

Avtäcka ett kunnande - forskningspraktikens betydelse ..........................6 64

Inifrån- och utifrånperspektiv i forskningen .................................... 65

Iterativ design - i en dynamisk och komplex klassrumskontext ............. 67

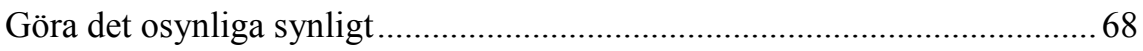

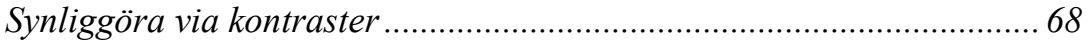

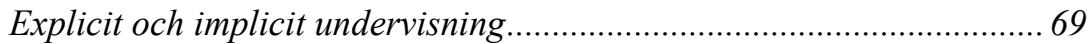

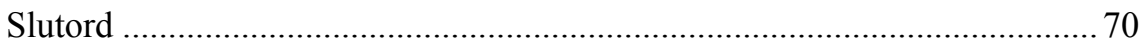

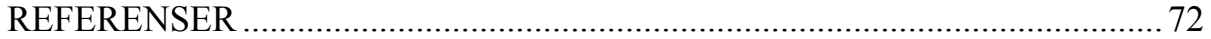

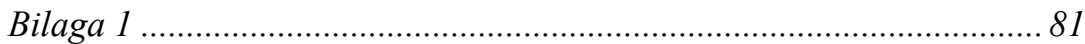

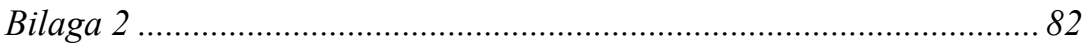





\section{INTRODUKTION}

Vad innebär det att kunna skriva en berättelse? Hur kommer det kunnandet till uttryck hos 9-10-åringar? Och hur är det möjligt att i en forskningsprocess studera och utveckla elevers kunnande? Det är frågor som är centrala i denna avhandling. Gemensamt för frågorna är att de ur olika perspektiv berör kunnande i berättelseskrivande - hur det kan studeras, beskrivas och utvecklas. Kunnande ${ }^{1}$ ska i detta sammanhang förstås som den ämnesspecifika förmåga som undervisningen avser att utveckla (se Carlgren, 2011). Undersökandet av ett kunnande innebär ett undervisningsnära forskningsintresse. Flera forskare (Carlgren, 2012, 2017; CochranSmith, 2009; Hiebert, Gallimore \& Steigler, 2002; Stenhouse, 1981) hävdar att när forskningen fokuserar på undervisning, har lärarerfarenheten betydelse för forskningsprocess och resultat. Forskningsintresset i föreliggande avhandling har vuxit fram ur min egen bakgrund som lärare och ur min erfarenhet av att forska tillsammans med andra lärare. Kunnandet att skriva berättelser närmas på två sätt, dels ur ett svenskdidaktiskt perspektiv, dels metodologiskt. Det handlar om att öka kunskapen om elevers berättelseskrivande i skolan och om hur lärarerfarenheten i kombination med teorianvändande kan generera ämnesdidaktisk kunskap.

När jag arbetade som lärare gav jag ofta eleverna i uppgift "att skriva en berättelse". Jag provade olika metoder, men upplevde att det fanns delar i elevernas skrivande som var svåra att utveckla. Ur det föddes en nyfikenhet och en vilja att undersöka detta vidare. Jag och mina kollegor upplevde att många elever i årskurs 3 och 4 hade svårt att skriva berättelser med ett välutvecklat händelseförlopp, vilket gjorde att det blev ett intressant område att studera och utveckla undervisningen i. En liknande upptäckt gjordes av Nordlund (2016). Hennes resultat visar att handlingen i en berättelse är ett område som elever i årskurs 3 kan ha svårigheter med, vilket Nordlund menar kan bero på att det är ett undervisningsinnehåll som får alltför lite utrymme. Enligt McKeough (1984; 1987) är barn i 10-årsåldern redo att ta ett utvecklingskliv mot att skriva berättelser med en mer komplex uppbyggnad. Den här avhandlingen bidrar med att fördjupa kunskapen om barns berättelseskrivande och om hur skrivandet kan utvecklas så de kan ta det utvecklingsklivet.

Inom läs- och skrivfältet har läsforskning fătt större utrymme än skrivforskning. Thygesen och Berge (2015) menar därför att det finns behov av fler studier som behandlar skrivande och skrivdidaktiska frågor. Flera av studierna inom skrivande har fokuserat på den tidiga skrivinlärningen och på läs- och skrivsvårigheter,

\footnotetext{
${ }^{1}$ Dewey och Bentley (1949) använder begreppen knowing och known, där knowing står för kunnandet och known står för kunskapen. Kunskapen kan ses som vetandet av något, som ett stoff eller ett kunskapsinnehåll. Kunnandet kan beskrivas som en förmåga och visar sig i det sätt varpå något utförs. Kunnandet och kunskapen är inte fristående från varandra, utan de är ömsesidigt beroende av varandra.
} 
medan den fortsatta skrivinlärningen och skrivutvecklingen inte är beforskad i samma utsträckning. Christie och Derewianka (2008) påtalar att fasen efter den första skrivinlärningen, vilken brukar inträda i 9-10-årsåldern, har stor betydelse när det gäller att utveckla elevers skriftspråkliga kompetens, särskilt avseende att skriva i olika genrer. Det finns rikligt med forskning om barns berättelser utifrån ett kognitivt utvecklingsperspektiv (Stein och MacKeough är framträdande namn) och utifrån systemisk funktionell lingvistik ${ }^{2}$ (bland annat Nordlund, 2016). Däremot är det fortfarande sparsamt med forskning utifrån andra perspektiv. Eftersom 9-10-årsåldern är så viktig för elevers bemästrande av skriftspråklighet behövs det fler perspektiv på hur elever hanterar skrivandet i dessa åldrar och också på hur undervisningen kan möjliggöra att eleverna utvecklar sitt berättelseskrivande. Ny forskning kan bidra med bredare och djupare kunskap inom området.

Den forskning som finns om skrivundervisning har bedrivits på flera olika sätt, allt från storskaliga kvantitativa metaanalyser till kvalitativa fallstudier. Graham, Harris och Chambers (2016) har gjort en forskningsöversikt av andra forskningsöversikter om skrivundervisning, för att ge det de beskriver som evidensbaserad kunskap om fältet. I sin analys har de främst utgått från översikter över kvantitativa interventionsstudier där resultaten redovisas i effektstorlek, men de har även kombinerat analysen med vetenskapliga studier av duktiga skrivpedagogers arbete. Graham et al. (2016) kritiserar kvalitativa studier som utgår från lärares egen erfarenhet, eftersom det är svårt att generalisera dem och urskilja vilka variabler som har påverkat undervisningen. Studier med ett lärarperspektiv är således inte med i deras analys. Resultaten i forskningsöversikten visar på områden som har hög effektstorlek och som är centrala $i$ all typ av skrivundervisning, såsom vikten av feedback samt att läraren explicit behöver undervisa om skrivstrategier och skrivfärdigheter. Storskaliga metastudier av denna typ kan ange riktlinjer och identifiera mönster för vad som fungerar på en övergripande nivå. De är därför lämpliga för att besvara frågeställningar om vilka faktorer som fungerar på en generell nivå. Det finns dock risk för att resultaten blir för övergripande och oprecisa. De belyser inte vissa delar som kan ha avgörande betydelse i skrivundervisningen, vilket är något som även Graham et al. (2016) påtalar. Följaktligen behövs även närstudier. Ett område som inte behandlas i forskningsöversikten av Graham et al. (2016) är vad olika specifika skrivkunnanden innebär och vad som behöver synliggöras i undervisningen för att eleverna ska utveckla ett nytt kunnande i till exempel berättelseskrivande. Det är inom det området som föreliggande avhandling ämnar ge ett bidrag.

När ett kunnande ska undersökas och utvecklas behövs metoder som gör det möjligt att adressera just dessa frågor. En metod som har prövats i flera studier för att generera denna typ av kunskap är Learning study (Carlgren, 2017; Marton,

\footnotetext{
${ }^{2}$ Systemisk-funktionell lingvistik beskrivs i avsnittet "Undervisa om berättelseskrivande" i kapitel 2.
} 
2015). Fokus i Learning study ligger på att undersöka hur undervisningen kan utvecklas inom ett specifikt, avgränsat ämnesområde (Pang \& Marton, 2003; Lo, 2012). I en iterativ process analyseras elevernas kunnande, och lektioner designas och genomförs. Därefter analyseras och revideras lektionerna, innan de återigen testas i en ny undervisningsgrupp. Ett kännetecken för Learning study är att en teori om lärande används i processen. Variationsteorin har ofta kombinerats med Learning study, vilket är fallet även i föreliggande avhandling. Ett annat karaktärsdrag för Learning study är att lärare är medforskare i hela processen, vilket möjliggör att lärares erfarenhetsbaserade kunskap påverkar forskningsprocess och resultat (Carlgren, Eriksson \& Runesson, 2017). Resultat från studier med Learning study som metod tenderar att ha hög ämnesdidaktisk relevans och vara av stort intresse för verksamma lärare (Carlgren, 2017). Vad det är i forskningsprocessen som gör att denna typ av resultat kan genereras är fortfarande sparsamt beforskat. Den metodologiska delen i denna avhandling kan bidra med ytterligare kunskap inom det området.

Avhandlingen som helhet behandlar således hur elevers kunnande i berättelseskrivande kan utvecklas, inriktat dels mot elevers kunnande i en undervisningskontext, dels mot hur forskningsprocessen möjliggör undersökning av kunnandet.

\section{Syfte och forskningsfrågor}

Syftet med föreliggande avhandling är att öka kunskapen om hur elevers kunnande i berättelseskrivande kan beskrivas, studeras och utvecklas. Bidraget är både svenskdidaktiskt och metodologiskt. Det svenskdidaktiska bidraget fokuserar på vad som behöver synliggöras i undervisningen för att elever i 9-10-årsåldern ska kunna utveckla sitt kunnande i berättelseskrivande. Utgångspunkten är de olika sätt som 9-10-åringar erfar berättelseskrivande på och vad de i undervisningen behöver få möjlighet att erfara och urskilja för att utveckla kunnandet ytterligare. Det metodologiska bidraget i avhandlingen handlar om hur forskningsprocessen $\mathrm{i}$ Learning study kan möjliggöra att kunskap om kunnande kan genereras. Då fokuseras främst betydelsen av lärares erfarenhetsbaserade kunskap i kombination med teorianvändning. Avhandlingen avser att behandla en övergripande frågeställning som specificeras i ytterligare två frågor.

\section{Frågeställningar}

Hur kan kunnandet att skriva berättelser göras undervisningsbart?

a) Vad behöver 9-10-åringar erfara för att kunna skriva berättelser med ett välutvecklat händelseförlopp?

b) Hur används lärares erfarenhetsbaserade kunskap tillsammans med variationsteori när ett kunnande om berättelseskrivande undersöks och utvecklas i en Learning study? 
Frågeställningarna besvaras i avhandlingens fyra publikationer. Publikation I är en licentiatuppsats (Thorsten, 2014) som syftar till att beskriva vad elever i årskurs 3 och 4 behöver urskilja samt vad som behöver synliggöras i undervisningen för att eleverna ska kunna skriva berättelser med ett välutvecklat händelseförlopp. I publikation II (Thorsten, accepterad) analyseras elevberättelser, och resultatet visar olika sätt som eleverna hanterar berättelseskrivande på och vilka aspekter som skulle behöva synliggöras i undervisningen. I publikation III (Thorsten, 2015) och IV (Thorsten, 2017) belyses forskningsprocessen med fokus på hur lärarerfarenheten och variationsteorin har använts.

\section{Avhandlingens disposition}

Avhandlingen är uppbyggd kring ett intresse av att beskriva, studera och utveckla kunnandet att skriva berättelser, det vill säga hur det går att göra ett kunnande undervisningsbart. Avhandlingen inleds med tre bakgrundskapitel. I det första bakgrundskapitlet, kapitel 2, finns en beskrivning av berättelser och berättelseskrivande, vilken avslutas med berättelseskrivande i en skolkontext. I kapitel 3 behandlas variationsteorin, det vill säga den teori om lärande som har använts i avhandlingen. I det avslutande bakgrundskapitlet, kapitel 4, ligger fokus på forskningsprocessen. Då behandlas forskning och teorier som berör hur ett kunnande kan undersökas och utvecklas, fokuserat på forskningsmetoden Learning study. I kapitel 5 tas de olika metoder som har använts i avhandlingens publikationer upp. I detta kapitel finns också ett avsnitt om etiska aspekter. Kapitel 6 beskriver de fyra studier som ingår i avhandlingen och i det sista kapitlet (kapitel 7), diskuteras avhandlingens resultat. Metoddiskussionen är invävd i metodbeskrivningarna i kapitel 5 och i diskussionsavsnittet. 


\section{BERÄTTELSESKRIVANDE}

Kunnandet att skriva berättelser står i relation till vad en berättelse är och hur den kan beskrivas. Detta kapitel inleds därför med en beskrivning av grundläggande kännetecken för en berättelse utifrån dess funktion, innehåll och form. Därefter belyses barns berättande och berättelseskrivande. Eftersom skriftligt berättande är i fokus, beskrivs också skrivande och skrivutveckling baserat på vilka förmågor som behöver behärskas samt olika teoretiska perspektiv på skrivande. Avslutningsvis behandlas studier som har undersökt undervisning av berättelseskrivande.

\section{Vad är en berättelse?}

För att kunna undervisa om berättelseskrivande behövs kunskap om vad en berättelse är, vad det innebär att kunna skriva en berättelse och vad de som bemästrar hantverket gör, det vill säga en analys av själva kunnandet.

Historiskt har berättande främst skett i muntlig form, även om gestaltningar och bilder också förekommit (Ong, 1982). I det moderna samhället återfinns berättande i flera modaliteter, där den skriftliga formen har givits särskilt stort utrymme (Bruner, 2002; Chatman, 1978; Ong, 1982). Trots att skriftligt berättande är en relativt ny företeelse har det påverkat både berättandet och berättelsestrukturen i dagens berättelser (Ong, 1982). I skriftlig form kan en berättelse bearbetas betydligt mer än i muntlig form. Den kan också delas, bevaras och läsas i en helt annan kontext, vilket påverkar struktur, innehåll och språk.

Enligt Holmberg (2014) kan en berättelse gärna belysas ur två perspektiv: ett utifrånperspektiv, som fokuserar mening och funktion, och ett inifrånperspektiv med fokus på struktur och form. Innehållet i berättelsen är relaterat till båda dessa perspektiv. Nedan kommer därför berättelser och berättandet beskrivas baserat på funktion, innehåll och form. Den inledande beskrivningen av berättelsens funktion följs av en beskrivning av dess innehåll och form, baserat på narratologiska teorier. Dessa teorier innehåller begrepp och tankemodeller som beskriver berättelsens uppbyggnad, berättartekniska grepp, analysmetoder med mera. Teorierna ger en bra grund till att förstå berättelsen ur ett inifrånperspektiv genom att de synliggör vilka komponenter som en skribent har att hantera i berättelseskrivandet.

\section{Berättelsens funktion}

Berättandet är något djupt mänskligt (Bruner, 2002; Ong, 1982; Stein, 1982). Det har en central plats i de flesta kulturer och kan tillskrivas flera funktioner. Ong (1982) framhåller att berättelsen och berättandet historiskt har fungerat som ett sätt att bevara kulturen och att överföra värden från en generation till en annan (se även Bruner, 2002; Stein, 1982). I berättandet i talspråkliga kulturer var den funktionen 
central, eftersom berättandet innebar ett strukturerat sätt att föra vidare lärdomar, kunskaper och instruktioner (Ong, 1982; Stein, 1982).

Vidare beskriver Ong (1982) en annan viktig roll som berättelsen har och har haft, nämligen att den möjliggör för människor att dela och bearbeta erfarenheter. Enligt Bruner (2002) kan berättelsen och berättandet göra att nya perspektiv framkommer, vilket kan leda till nya förhållningssätt och nya sätt att möta och förstå omvärlden. Det innebär att personliga och sociala dilemman kan bearbetas eller belysas. Stein (1982) hävdar att berättande därför kan ha en närmast terapeutisk funktion.

Berättandet och berättelsen har också en viktig funktion i form av att underhålla (Stein, 1982). Det ger människor en möjlighet att njuta och att koppla av. Stein framhåller dock att underhållandet inte bara behöver tolkas som att upplevelsen av berättelser ger positiva känslor. Berättelser får oss att bli berörda, att fantisera och skratta, men också att känna smärta och gråta. Ett slags magi kan uppstå både i skapandet och i mottagandet av berättelser, vilket Bruner (2002) menar kan möjliggöra upplevelser av nya världar och på så sätt skapa källor till både sorg och glädje.

Det fiktiva berättande som sker i en skolkontext och som behandlas i föreliggande avhandling, har mest likheter med den sistnämnda funktionen, det vill säga att underhålla. Därmed inte sagt att berättandet inte också kan ha andra funktioner. Säkerligen kan skapandet av berättelser, åtminstone för vissa elever, också fungera som ett sätt att bearbeta erfarenheter, vilket beskrivs av Bruner (2002).

\section{Berättelsens innehåll - story}

Berättelsens innehåll, dess handling, benämns som story inom narratologin (Chatman, 1978). Handlingen byggs upp av händelser och karaktärer som finns i något slags miljö (Chatman, 1978, Propp, 1928/2015). Den enklaste storyn innebär att en karaktär gör något som leder till en förändring av ett tillstånd. Stein och Glenn (1979) beskriver att handlingen består av episoder. Dessa episoder utgår från initiala händelser med något slags problem som karaktärerna reagerar på. Även Bruner (2002) framhåller att det $\mathrm{i}$ en berättelse behöver uppstå något slags problem, något oväntat som bryter det förväntade $\mathrm{i}$ berättelsens uppdiktade värld. Utan problem eller dilemman skulle det inte finnas något att berätta om. En klassisk berättelse binds vanligen samman av en orsak-verkan-sekvens som kretsar runt ett eller flera problem och som avslutas med en upplösning (Bruner, 2002; Chatman, 1978). Ong (1982) påtalar dock att denna struktur inte stämmer för äldre muntliga berättelser som i stället är uppbyggda kring löst sammansatta episoder. Även moderna berättelser kan ha en alternativ typ av uppbyggnad. I stället för den klassiska upplösningen, kan de avslutas med ett avslöjande om hur något är (Chatman, 1978). I barnlitteratur är dock den klassiska berättelsestrukturen med intrig och upplösning vanligast (Schmidt, 2010), och det är också denna struktur som fokuseras i föreliggande avhandling. 
Propp (1928/2015) analyserade klassiska berättelser i form av ryska sagor. Han undersökte hur själva händelseförloppet byggs upp, genom att beskriva vilka funktioner som finns i en saga. Propps funktioner kan beskrivas som handlingar eller händelser som driver berättelsen framåt. Totalt beskriver han 31 funktioner. Dessa delas in i fyra faser: (1) introduktion, (2) berättelsen byggs upp, (3) hjälten löser problemet och (4) hjältens återkomst. I varje fas finns ett antal funktioner, till exempel någon försvinner, hjälten testas och hjälten återvänder. Alla 31 funktioner finns inte representerade i alla berättelser, men enligt Propp (1928/2015) är den övergripande strukturen densamma i alla berättelser.

Även Chatman (1978) intresserar sig för berättelsers struktur i relation till dess innehåll, men på ett annat sätt än Propp. Chatman menar att Propps analys blir begränsad, då den inte går att applicera på alla berättelser och sagor. Enligt Chatman gör det att Propps analys, och andra liknande analyser, blir ointressanta eftersom det finns så många undantag. I stället för att använda givna funktioner föredrar Chatman (1978) att analysera en berättelse utifrån dess narrativa block. Varje sådant block består av ett problem och en lösning. Blocken är uppbyggda av kärnhändelser (kernels), vilka är centrala händelser som bär upp storyn, och satelliter (satellites), vilka är sidohändelser som "kryddar" och berikar storyn. Genom att analysera storyn i narrativa block, baserat på kärnhändelser och satelliter, skulle det vara möjligt att beskriva typberättelser som är uppbyggda på olika sätt (Chatman, 1978).

Både Propps och Chatmans teorier och sätt att analysera har i denna avhandling fungerat som inspiration i analysen, vilket beskrivs i kapitel 5. Chatmans ifrågasättande av generaliserbarheten i Propps analys är säkerligen rimlig. Andra forskare har dock visat att Propps resultat kan vara användbara som utgångspunkt $i$ analyser av till exempel barns berättelser (se till exempel Asplund Carlsson, Pramling Samuelsson, Soponyai, \& Wen, 2001). I den här avhandlingen har inte Propps resultat i sig varit en utgångspunkt. Däremot har hans analysmetod fungerat som inspiration, eftersom den erbjuder ett redskap för analys av en berättelses struktur.

\section{Berättelsens form - diskurs}

Hur berättelsen kommuniceras till en tänkt läsare kallas inom narratologin för diskurs (Chatman, 1978; Genette, 1972/1980). Vem som är den tänkta mottagaren för det berättade är centralt för hur berättelsen berättas. Iser (1972/1974) benämner denna mottagare som en implicit läsare. Den implicita läsaren är oftast inte en konkret, verklig läsare, utan snarare en konstruktion bestående av en idé av en möjlig läsare. Genom uppbyggnaden av sin text skapar författaren förutsättningar för en läsare att gå in i texten, men det är när texten läses av en verklig läsare som egentlig mening skapas.

När en berättelse ska berättas finns det flera skillnader jämfört med om storyn skulle ha skett i verkligheten (Genette, 1972/1980). I berättelsen kan ordningen vara en annan än den kronologiska ordningen. Det kan finnas både framåtblickar 
och tillbakablickar. En annan del som skiljer sig är hur mycket utrymme något får i relation till hur mycket tid det skulle ta om det hade hänt på riktigt, vilket benämns som duration av Genette (1972/1980). Vissa händelser i storyn får alltså mycket utrymme, medan andra inte alls nämns. Kortare händelser kan beskrivas i detalj över flera sidor, och andra händelser beskrivs översiktligt (till exempel "tre år senare"). Växlingen sker ofta både i tid och i plats. Hur författaren hanterar utrymmet beror, enligt Chatman (1978), på hur författaren vill att berättelsen ska drivas framåt.

En annan aspekt som varierar är ur vilken synvinkel en berättelse berättas. Berättelsen kan utgå från någon av karaktärernas perspektiv, växla perspektiv eller kanske ha en allvetande berättares perspektiv (Genette, 1972/1980). Den kan också berättas ur första eller tredje person.

En berättelses form, innehåll och funktion kan analytiskt särskiljas. I den reella berättelsen är dock dessa delar sammanvävda. Berättelsens funktion påverkar både form och innehåll, och innehållet och formen ger i sin tur ömsesidigt möjligheter och begränsningar för hur berättelsen framträder som helhet.

\section{Barns berättelseskrivande}

I avsnittet ovan beskrevs berättelseskrivande utifrån hur en som bemästrar kunnandet hanterar det. De narratologiska teorierna, med fokus på innehåll och form, bildar en grund för att beskriva skrivandets hantverk. De är relevanta även för barns skrivande, men måste relateras till elevernas utvecklingsnivå och förmåga. För att kunna skriva en berättelse behöver eleven behärska flera olika förmågor, som är relaterade till både berättande och skriftspråk. Därför inleds detta avsnitt med att lyfta fram fyra centrala förmågor (den narrativa strukturen, kreativitetens betydelse, användande av skriftspråket och sammanhang i skriven text) och hur elever i olika åldrar hanterar dem. Därefter ges en fördjupning i skrivutvecklingsteorier ur olika perspektiv. Anledningen är att grundsynen på skrivande och skrivutveckling även påverkar undervisningen i skrivande.

\section{Hantering av den narrativa strukturen}

Den klassiska narrativa strukturen, med inledning, komplikation och lösning, syns i olika utsträckning i barns skrivande. Baserat på Stein och Glenns (1979) definition av en berättelse, studerar McKeough (1984; 1987) och McKeough och Genereux (2003) förekomsten av problem och lösningar i berättelser samt på vilket sätt de eventuella problemen löser sig. Forskarna använder ett kognitivt utvecklingsperspektiv och beskriver hur typiska berättelser från barn i åldern 4-17 år är uppbyggda. Även om det finns individuella avvikelser menar de att barn på gruppnivå går igenom samma faser och att faserna följer deras kognitiva mognad. Beskrivningen nedan baseras på McKeoughs $(1984 ; 1987)$ och McKeoughs och Genereuxs (2003) forskning, med en tonvikt på faserna upp till 12-årsåldern, eftersom de är mest relevanta i föreliggande avhandling: 
1. 4-åringars berättelser består av en serie händelser, utan någon tydlig intrig.

2. I 6-årsåldern sker en viktig brytpunkt, eftersom det är i denna ålder som barn börjar bygga upp sina berättelser utifrån en intrig. I denna fas är intrigen enkel och består av ett problem som löser sig direkt.

3. 8-åringars berättelser har samma grundstruktur som 6-åringars, men nu kan berättelsen även innehålla någon komplikation som är kopplad till problemet. Komplikationen löser sig snabbt, i samband med att berättelsens huvudsakliga problem löser sig.

4. I 10-årsåldern börjar berättelserna ha en mer sammanhållen struktur, i vilken det inbegrips fler komplikationer. Berättelsen brukar avslutas med en lösning som är väl kopplad till berättelsen som helhet.

5. I 12-årsåldern sker en ny brytpunkt. Här inkluderas karaktärernas intentioner och karaktärsdrag i hela berättelsen. Dessutom innehåller berättelsen sidospår, i form av till exempel tillbakablickar.

6. Allteftersom eleverna blir äldre integreras karaktärernas inre och yttre liv, med en berättelsestruktur som kan innehålla flera olika spår, men som knyts ihop till en helhet.

Annan forskning visar likande resultat gällande barns utveckling i berättande. I Alamargots och Fayols (2009) sammanställning av flera studier syntes stora individuella skillnader mellan barn, men på en övergripande nivå framkom att 4-5åringar inte har en tydlig narrativ struktur. Barn i denna ålder beskriver snarare enskilda händelser som inte kopplas samman. Alamargots och Fayols resultat tyder också på att det är i 6-8-årsålderna som de flesta barn behärskar den grundläggande narrativa strukturen i sina berättelser. När de sedan blir 8-9 år kan de oftast också behärska tid, plats och karaktärer. Det är först i 10-årsåldern som de flesta barn klarar att hantera temporala och kausala samband (ibid.). Även i Christies och Derewiankas (2008) analys av elevberättelser framkommer att elever i 6-8-årsåldern har en klassisk berättelsestruktur men att komplikationen är enkel. I 9-12årsåldern byggs berättelsen ut med rikare information om karaktärer, händelser och platser.

Utvecklingen av berättelsestruktur har även studerats av Evensen (2006). Han beskriver utifrån sin forskningsöversikt att barn redan i förskoleåldern har flera genrespecifika drag och en grundläggande genrestruktur i sina berättelser. Detta visar, menar Evensen, att skrivutveckling mycket väl kan handla om inveckling snarare än utveckling av texter, vilket innebär att barnen först etablerar den övergripande strukturen för att sedan lyckas lägga till fler och fler detaljer ju längre de kommer i sin skrivutveckling. Nordlund (2016) har i en longitudinell studie från årskurs 1-3 analyserat elevtexter utifrån ett systemiskt-funktionellt perspektiv. I studien framkom att det finns väsentliga skillnader mellan eleverna avseende hur tydlig handling de har i sina berättelser. I alla årskurser har vissa elever en tydlig 
handling, några otydlig handling och ytterligare några ingen handling alls. I jämförelsen mellan individuella elevers utveckling mellan årskurs 1 och 3 visade det sig att de flesta elever hade utvecklat sin övergripande språkliga förmåga. Däremot var denna utveckling inte lika tydlig när det gällde berättelsens narrativa struktur.

Barn möter berättelser i olika former även på fritiden, vilket påverkar deras skrivande och utveckling av struktur och språk (Olin-Scheller \& Wikström, 2010). I den så kallade "fan-fiction"-kulturen är utgångspunkten redan skrivna berättelser, till exempel Harry Potter, som barnen fortsätter att skriva egna berättelser utifrån. I dessa fall står ursprungsberättelsen för den övergripande narrativa strukturen. Ursprungsberättelsen fungerar då som ett stöd och kan, enligt Olin-Scheller och Wikström (2010), hjälpa barn att utveckla förmågan till att också självständigt skriva berättelser. Även Lenters (2016) påtalar att struktur och innehåll i barns berättelser påverkas av den kultur som de är en del av. Till exempel har uppbyggnaden i tvoch dataspel en berättelsestruktur som delvis skiljer sig från den klassiska berättelsestrukturen, eftersom den bland annat inte innehåller något tydligt avslut. När barnen sedan skapar egna berättelser går det därför att se spår av andra strukturvarianter (ibid.).

\section{Betydelsen av kreativitet}

Den kreativa förmågan anses av flera forskare vara central i elevers berättelseskrivande (Bardot, Tan, Randi, Santo-Donato \& Grigorenko, 2012; Bayat, 2016; Cheung, 2005; Vygotskij, 1950/1995; Temizkan, 2011). Bardot et al. (2012) har sammanställt forskning om vad som är viktigt för att utveckla yngre elevers berättelseskrivande. De har granskat studier från olika professioner och identifierat centrala förmågor som beskrivs av lärare, psykologer, författare, museipedagoger och lingvistiker. Deras resultat visar att de deltagande professionerna framhöll elevernas kreativa förmåga som viktigast för att kunna skriva en berättelse. Kreativitet beskrivs i studien som förmågan att generera idéer, associera, tänka i nya banor och fantisera.

Vygotskij (1950/1995) beskrev tidigt vikten av kreativitet och fantasi vid berättande och berättelseskrivande. Vygotskij karakteriserar kreativitet som förmågan att kunna kombinera olika erfarenheter och upplevelser till något nytt. Dessa erfarenheter behöver inte bara vara egenupplevda, utan de kan också bygga på sådant som personen har sett, hört eller läst. I den kreativa processen kombineras, samt förstoras och förminskas, olika delar av den egna referensvärlden. Det ger en helt ny skapelse, och det är det som upplevs och beskrivs som fantasi. Enligt Vygotskij har vuxna människor rikare fantasi än vad barn har, eftersom de vuxna vanligtvis har upplevt mer och har fler erfarenheter. Senare forskning bygger på samma grundantagande. När elever fär idéer till sitt skrivande är grunden de egna erfarenheterna och upplevelserna (Barbot et al., 2012; Bruner, 2002; Graves, 1994; Hayes, 2006). Trots detta kan barns fantasi upplevas som rikare än vuxnas. Vygotskij (1950/1995) menar att detta beror på att barn inte kritiskt granskar sina idéer och sin fantasi på samma sätt som vuxna. Detta leder till att deras idéer får 
friare utrymme. Dessutom använder barn fantasin för att bearbeta och förstå sin omvärld, vilket gör att den ständigt är närvarande (ibid.).

Davydov (2008), som är en efterföljare till Vygotskij, diskuterar i sina texter fantasins och kreativitetens betydelse. Han beskriver att den kreativa förmågan är grundläggande för alla andra förmågor och att den därför är en förutsättning för teoretiskt tänkande. Marton (2015) argumenterar för att en förmåga alltid är kopplad till ett specifikt innehåll och att den inte går att se fristående från det innehåll som förmågan kopplas till. Med denna tolkning är kreativitet således inte en generell förmåga, utan kreativitet innebär att kunna koppla nya, värdefulla idéer till olika specifika områden (Marton, 2015). Det är alltså skillnad på att vara kreativ i relation till problemlösning i matematik och i relation till att fantisera ihop en berättelse. I berättelseskrivande innebär kreativitet att skapa idéer som utgör byggstenar till en berättelse. För att kunna göra det krävs både rika erfarenheter och förmåga att förstå berättelser och deras uppbyggnad. Olin-Scheller och Wikström (2010) visar i sin studie, där unga tjejer intervjuas om hur de skriver "fan-fiction", att tjejerna tycker att skolskrivandet är svårt, eftersom de måste fantisera ihop hela berättelsen själv. Därför kan, menar Olin-Scheller och Wikström (2010), befintliga berättelser fungera som en språngbräda in i genren eftersom de ger stöd när handlingen i en berättelse ska skapas. Om detta kopplas till Vygotskijs (1959/1995) idéer om kreativitet kan de färdiga berättelserna erbjuda byggstenar för nya fantasier.

De idéer som blir grunden för berättelsen ska i ett skolsammanhang ofta överföras till skrift. Det är i sig en utmaning för många barn (Alarmagot \& Fayol, 2009).

\section{Användande av skriftspråk}

Skriftspråket har vissa förutsättningar som skiljer det från vad som gäller i det talade språket (Ong, 1982). Flera av dessa skillnader har att göra med förmågan att dekontextualisera, det vill säga att uttrycka sig bortom här och nu. Talet är kopplat till det som händer i stunden, och världen runt omkring fungerar som gemensam referensram. I samtalssituationer finns också en mottagare närvarande som påverkar både vad och hur något berättas. Det gör att det muntliga inte behöver vara en färdig produkt, utan snarare kan växa fram under samtalets gång, i dialog med en eller flera andra personer (Alamargot \& Fayol, 2009; Ong, 1982). Skriften däremot kan inte kompletteras med tonfall, mimik och gester, och därför behöver det skrivna vara tydligare och mer exakt (Ong, 1982). Det behöver fungera självständigt, frikopplat från det sammanhang där det skapades. Norberg Brorsson (2007) har analyserat elevtexter och intervjuat elever i årskurs 7 och 8 om sitt skrivande, och framhåller att elevers texter påverkas av om de har en tydlig mottagare. I skolsammanhang är oftast mottagaren inte uttalad, men eleverna förstår ändå att det är läraren som är mottagare. Enligt Norberg Brorsson gör det att eleverna försöker räkna ut hur läraren vill att texten ska se ut. Hon menar att elevers skrivande 
skulle utvecklas om skolan i högre utsträckning skapade uppgifter med reella mottagare och tydliga motiv.

En väsentlig skillnad mellan talet och skriften är talets förgänglighet. Talet försvinner i samma stund som det har yttrats medan skriften finns kvar (Ong, 1982). Talspråket lär sig de flesta barn helt naturligt i det sociala sammanhang där de växer upp. Vissa forskare (till exempel Clay, 1991, och Prior, 2006) menar att även skriftspråket tillägnas i en socialiseringsprocess och att det bör vara utgångspunkten när barn lär sig behärska skriftspråket. Andra forskare (se Alamargot \& Fayol, 2009; Graham et al., 2016; Ong, 1982) framhåller att det krävs riktad undervisning för att lära sig behärska skrivandet fullt ut, även om vissa delar av skriftspråket går att införliva i en naturlig socialiseringsprocess. Vygotskij (1995/1950) menar att skriftspråket är en stor utmaning för barn i de första skolåren och att det kan begränsa deras förmåga inom andra ämnesområden. Därför är det vanligen enklare för barn att berätta muntligt än skriftligt.

I dag går det inte, enligt Halliday och Matthiessen (2004), att strikt dela upp språket i talat och skrivet språk. Snarare går det att beskriva vissa miljöer i tal eller skrift som att de innehåller starkare eller svagare drag av talspråk respektive skriftspråk. Till exempel har sms flera talspråkliga drag och telefonsamtal har drag av vad som krävs för skriftspråket. Halliday och Matthiessen (2004) påtalar att de texter som elever förväntas producera finns på en skala mellan talspråkliga drag och skriftspråkliga drag. Återgivande texter, där eleven berättar om en egen upplevelse, ligger närmare det talspråkliga än till exempel vetenskapliga rapporter som befinner sig i andra ändan av skalan. Den berättande texten ligger någonstans $\mathrm{i}$ mitten på den skalan. För att behärska skriftspråket fullt ut behöver skribenten förstå och hantera skriftspråkets särskilda förutsättningar, som handlar om allt från inkodning till att kunna strukturera upp en text och skapa sammanhang.

\section{Skapande av struktur och sammanhang i skriven text}

Att skapa struktur och sammanhang i en skriven text är en utmaning för många elever i de tidigare skolåren (Sanders \& Schilperoord, 2006). En elevtexts struktur kan studeras utifrån flera olika nivåer. Den globala nivån handlar om texten som helhet och det tema som genomsyrar hela texten (Sanders \& Schilperoord, 2006). Den lokala nivån berör enskilda ord, satser och meningar och hur de kopplas samman. Att kombinera den globala nivån med den lokala nivån har visat sig vara svårt för många elever. Elever kan till exempel ha problem med att genomgående hålla ett tema och att kombinera de enskilda delarna med helheten (Berninger, Fuller \& Whitaker, 1996; Sanders \& Schilperoord, 2006). I en studie där 900 elevberättelser från årskurs 1-9 analyserades, framkom att eleverna hade olika strategier för att skapa en helhet och binda samman olika delar (Berninger et al., 1996). I studien redovisas resultat som rör olika strategier på olika nivå i skrivutvecklingen. I de lägre nivåerna saknas helt samband mellan de lokala och de övergripande delarna i texten. De samband som finns bygger på associationer mellan meningar. I de 
högre nivåerna kan eleverna fördjupa vissa delar och också koppla ihop dem med textens övergripande tema.

\section{Teoretiska perspektiv på skriftspråklig utveckling och förmåga}

Barns allmänna skriftspråkliga förmåga har stor betydelse för hur de skriver berättelser. Därför är forskning som ur olika perspektiv belyser detta betydelsefull för att förstå vilka faktorer som påverkar skrivandet och vilka svårigheter elever kan ställas inför när de ska skriva en text. Blåsjö (2010) menar att skrivutveckling och skriftspråklig förmåga har beskrivits och beforskats ur företrädesvis det kognitiva respektive det sociokulturella perspektivet. I den kognitiva forskningen riktas intresset mot de mentala processer som pågår i individen vid en skrivsituation (Blåsjö, 2010; MacArthur \& Graham, 2016). Då beforskas vad skribenten kognitivt behöver bemästra för att producera en text, vilket inbegriper till exempel hur arbetsminnet fungerar, hur skribenten övervakar det egna skrivandet och vilka exekutiva funktioner som behöver fungera. Vid ett sociokulturellt perspektiv ligger i stället fokus på att skrivandet alltid sker i en kontext och utifrån särskilda syften (Bazerman, 2016). Det innebär att aspekter såsom skrivsammanhang, skrivhandlingar, motiv och interaktion blir centrala.

De flesta forskare är i dag eniga om att både kognitiva och sociokulturella faktorer är av betydelse för skrivandet och skrivutvecklingen (till exempel Christie \& Derewianka, 2008; Graves, 2003; Ivanič, 2004; Fasting, Thygesen, R., Berge, Evensen and Vagle; 2009; Mac Arthur \& Graham, 2016; Hayes, 2009), även om olika forskares forskningsintresse vanligen inriktar sig mot antingen kognitiva eller sociokulturella aspekter av skrivandet (Blåsjö, 2010).

\section{Mentala processer vid skrivandet - ett kognitivt perspektiv}

Flower och Hayes är två forskare med kognitiv inriktning som har blivit välkända för sin modell över skrivandets komponenter och över vad som sker i skrivprocessen (MacArthur \& Graham, 2016). Deras modell har ett kognitivt perspektiv och bygger på analyser av "tänka högt"-protokoll i samband med skrivande (Flower \& Hayes, 1981). Modellen söker beskriva de processer som sker i en skrivsituation. Utifrån modellen innebär skrivprocessen att skribenten behöver hantera flera aspekter samtidigt: förstå krav och förväntningar i skrivsituationen, använda befintliga kunskaper och bemästra själva skrivhantverket. Skrivprocessen som sådan är enligt Flower och Hayes (1981) uppbyggd runt planering, översättning (av tanke till text) och granskning. De båda forskarna påtalar att processen inte är linjär utan att skribenten övervakar de olika stegen och också växlar mellan dem. MacArthur och Graham (2016) framhåller i sin forskningsöversikt att Flower och Hayes har haft stor betydelse för skrivforskningen, dels eftersom de påbörjade arbetet med att visa komplexiteten i skrivandet, dels för att de skapade en begreppsapparat som även efterföljande forskare har använt sig av. Sociokulturella forskare har kritiserat 
modellen för att skrivandets sociokulturella aspekter inte gavs något utrymme, vilket gjorde att Flower och Hayes var för sig har vidareutvecklat modellen. Deras senare respektive modeller innehåller även dessa faktorer (MacArthur \& Graham, 2016).

Flera andra forskare har också utgått från Flower och Hayes modell och utvecklat den vidare. Scardamalia och Bereiter (1987) menade att Flowers och Hayes modell endast beskrev processen hos en kompetent skribent. De analyserade skrivalster och "tänka högt"-protokoll från själva skrivprocessen för skribenter i olika åldrar och med olika förmåga. Utifrån dessa analyser skapade Scardamalia och Bereiter en teori som går ut på att en omogen respektive en kompetent skribent har olika strategier. Skribenten har antingen en knowledge-telling strategy eller en knowledge-transforming strategy. Scardamalia och Bereiter beskriver att en och samma skribent kan växla mellan dessa strategier, bland annat beroende på hur familjär den aktuella genren är. En och samma skribent kan därför beskrivas som både omogen och kompetent, men i olika genrer. Den omogna skribenten använder en knowledge-telling strategy. Då fokuseras på några grundläggande genre-specifika drag och på själva ämnet. Skribenten har dock svårt att överblicka sin text och texten byggs upp utifrån de associationer som väcks i samband med skrivandet, baserat på ämnet som hen skriver om. Dunn och Finley (2010) benämner samma fenomen som online-planläggning, vilket innebär att det inte finns någon plan för struktur och uppläggning, utan det sker samtidigt med skrivandet. Scardamalia och Bereiter (1987) beskriver att den kompetenta skribenten i stället har en knowledgetransforming strategy, vilket innebär att skribenten fokuserar på att framföra innehållet på ett sätt som skapar en helhet och som blir läsarvänlig. Skribenten kan då växla fokus mellan form och innehåll. Skrivandet blir en problemlösande process där skribenten övervakar den egna textproduktionen och medvetet skapar en text $\mathrm{i}$ vilken både den retoriska aspekten och den innehållsliga aspekten beaktas. Enligt MacArthur och Graham (2016) har särskilt beskrivningen av knowledge-telling strategy styrkts i senare studier. De påpekar också att det i nuläget saknas studier som visar hur undervisning kan påverka så att eleverna övergår från knowledgetelling strategy till knowledge-transforming strategy.

Berninger och Amtmann (2003) har också tagit sin utgångspunkt i Flowers och Hayes modell. De förenklar modellen i sin teori "the simple view of writing". Där beskrivs skrivande som bestående av tre komponenter: (a) transkription, det vill säga en översättning av talat språk till skrivet språk, (b) textgenerering, vilket handlar om att skapa idéer och att sedan överföra dem till text, samt (c) självreglering, vilket inbegriper bland annat planering och organisering av texten. Enligt Berninger och Amtmann behöver yngre elever ofta lägga mycket kraft på transkriptionen, vilket gör att det finns mindre kraft kvar till andra delar av skrivandet. 


\section{Skrivande i ett sammanhang - ett sociokulturellt perspektiv}

Grundantagandet i det sociokulturella perspektivet är att skrivandet alltid är situerat $i$ en specifik kontext (Bazerman, 2016; Prior, 2006). Kontexten består av allt från språk och kultur till det mindre sammanhang där texten framställs.

Begreppet literacy används ofta för att beskriva skriftkompetens och hur skriften kan användas i olika sammanhang och för olika syften. Ett skriftspråks utveckling och funktion påverkas, enligt Scribner och Cole (1981), av den sociala praktik där det används. De har studerat Vai-folkets kognitiva kunnande i relation till de skriftspråk som vissa individer i folkgruppen behärskade: vai, arabiska och engelska. Dessa skilda skriftspråk lärdes in på olika sätt och användes i olika sammanhang och syften. Scribner och Cole (1981) fann att de kognitiva spridningseffekter som läs- och skrivförmågan i ett specifikt skriftspråk har, står i direkt relation dels till det specifika skriftspråkets uppbyggnad, dels till de sammanhang som skriftspråket används i. Det innebär att kunnande i skriftspråket i sig ger begränsade kognitiva effekter inom andra områden. Däremot uppstår flera effekter om skriftspråket utvecklas och används i en utbildning och i ett sammanhang som innehåller olika sociala praktiker där språket kan användas. Scribner och Cole (1981) uttrycker det så här: "If uses of writing are few, the skills they require are likely to be limited /.../ particular practices promote particular skills" (s. 258).

Den praktik där skriften används är därför avgörande för vilka förmågor som utvecklas. Eftersom allt skriftskapande, enligt Prior (2006), utgår från ett sociokulturellt sammanhang har varje skribent mer eller mindre uttalade medförfattare. Den dialog runt texten som skapas kan vara uttalad, då elever samarbetar kring en text, men medförfattarna existerar också på en annan nivå, eftersom individen alltid är influerad av det sociokulturella sammanhanget. Även läraren har en stark påverkan på elevernas skrivalster, $i$ allt från ämnesval och undervisningsinnehåll till rättning och kommentarer, och det innebär att läraren också kan ses som medförfattare till elevernas texter (ibid.).

Det finns olika försök att beskriva skrivandet som en situerad aktivitet. Ett norskt forskningsteam har utarbetat en teori om skrivande där en utgångspunkt är att skrivandet alltid sker i en kulturell och situationell kontext, men att även kognitiva faktorer har betydelse. Teorin beskrivs bland annat i Fastings et al. (2009) och i Thygesen och Berge (2015). Forskarteamet har samarbetat med verksamma lärare när de skapade modellen, vilket gör att den bygger på en kombination av forskningsresultat och lärares praxiserfarenhet. I modellen definieras skrivande $\mathrm{i}$ form av handlingar, syften och förmågor. Enligt Thygesen och Berge (2015) är skrivhandlingar alltid kopplade till en kontext, vilket gör att det inte går att ge en enkel förklaring till vad skrivande är. Just därför är deras modell flexibel. Modellen kallas Skrivhjulet och utgångspunkten är att skrivandet kan ha sex olika funktioner och att dessa funktioner kan kopplas ihop med olika skrivhandlingar. Funktionerna beskriver syftet med skrivandet, exempelvis konstruera fantasivärldar, kunskapsutveckling eller påverkan. De olika funktionerna kommer sedan till uttryck i olika skrivhandlingar, till exempel att berätta och underhålla eller att överbevisa och 
argumentera (Thygesen \& Berge, 2015). Det finns inte någon absolut koppling mellan en viss funktion och en viss skrivhandling. Handlingen att berätta kopplas vanligen till syftet att konstruera fantasivärldar, men även andra kopplingar är möjliga. Till exempel kan handlingen att berätta ha syftet att påverka.

\section{En kombination av perspektiven i ett didaktiskt sammanhang}

Allt fler forskare menar att båda det kognitiva och sociokulturella perspektivet behövs och att de kompletterar varandra (Blåsjö, 2010). De bidrar med att ur olika infallsvinklar förklara komplexiteten i en skrivsituation. En forskare som söker beskriva både kognitiva och sociokulturella aspekter av skrivandet är Ivanič (2004). Enligt Ivanič (2004) går det att se på text och textskapande som fyra olika lager, vilka bäddas in i varandra, och där både kognitiva och sociokulturella aspekter finns med. Se figur 1.

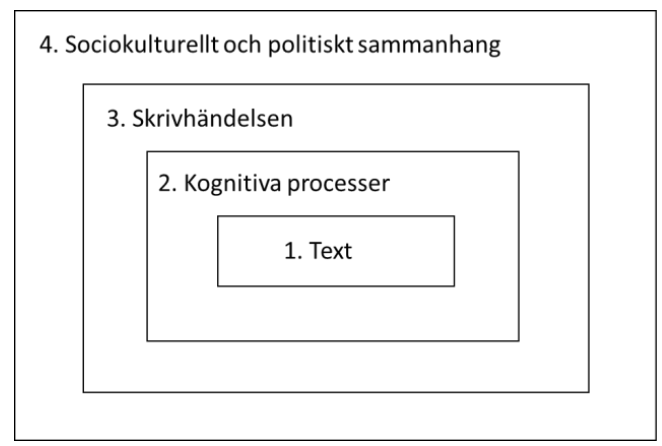

Figur 1. En modell över språk, baserad på "A multi-layered view of language" (Ivanič, 2004, s. 223).

I det första lagret finns själva texten med dess språk, innehåll, struktur och uppbyggnad. Det andra lagret beskriver de individuella kognitiva processer som sker hos skribenten. De båda yttersta lagren handlar om den sociala kontexten. I det tredje lagret finns den aktuella skrivhändelsen, det vill säga det sammanhang i vilket texten produceras. I det yttersta lagret beskrivs det större sociokulturella sammanhanget. Ivanič (2004) menar att olika typ av forskning riktar sig mot olika nivåer i modellen.

Ivaničs modell fungerar som ett bra tankeredskap för att belysa faktorer som påverkar skrivprocessen. Däremot ger den inte redskap för hur undervisning kan möjliggöra att eleverna utvecklar ett specifikt kunnande. Eftersom föreliggande avhandlings huvudsakliga forskningsfråga handlar om att göra ett kunnande undervisningsbart, används därför en specifik lärandeteori (variationsteorin) som fungerar i detta syfte. Variationsteorin beskrivs i kapitel 3 . 


\section{Undervisa om berättelseskrivande}

Eftersom de flesta barn växer upp i en miljö av berättelser i olika former (till exempel i form av högläsning, filmer och muntligt berättande), verkar det som att vissa grundläggande delar av berättandet uppstår helt naturligt för många barn (Bruner, 2002). Däremot, menar Bruner (2002), är de mer avancerade delarna av berättandet betydligt svårare att urskilja. Det gör att undervisningen får stor betydelse för utvecklandet av barns berättande. Skrivundervisningens innehåll och upplägg har varierat under de senaste årtiondena, liksom de antaganden om skrivande som den baseras på (Blåsjö, 2010; Graham et al., 2016; Ivanič, 2004; Manery, 2015).

\section{Skrivdidaktiska diskurser}

Ivanič (2004) har gjort en metaanalys av teori och forskning om skrivande och skrivpedagogik. Baserat på the multi-layered view of language (se figur $1 \mathrm{i}$ föregående avsnitt), identifieras sex diskurser. Ivanič definierar en diskurs som en samling antaganden rörande skrivande, skrivutveckling och skrivundervisning. De sex diskurserna är:

(a) den kreativa diskursen

(b) den processorienterade diskursen

(c) genrediskursen

(d) färdighetsdiskursen

(e) social praktik-diskursen

(f) den sociopolitiska diskursen.

Ivaničs underlag kommer från engelsktalande länder och han beskriver att olika diskurser har varit mer framträdande än andra i olika tidsperioder. Blåsjö (2010) skriver att skrivundervisningen i Sverige under de senaste årtiondena främst har utgått från det expressiva skrivandet (vilket är detsamma som Ivaničs beskrivning av den kreativa diskursen), processorienterat skrivande och genrepedagogik. För att sätta in föreliggande avhandling i ett skrivdidaktiskt, svenskt sammanhang beskrivs dessa tre skrivskolor lite mer ingående, med utgångspunkt i Ivaničs diskursiva analys. Ivaničs andra tre diskurser beskrivs mer kortfattat.

En av de största förespråkarna för det expressiva skrivandet, eller den kreativa diskursen, är Elbow (2000). Han menar att skrivandet ska ge eleven möjlighet att fritt uttrycka sina tankar, sina känslor och sin inre värld. Eleven ska få möjlighet att hitta sin egen personliga röst och komma in i ett kreativt flöde (Chandler \& Schneider, 2009; Elbow, 2000; Ivanič, 2004; Waitman \& Plucker, 2009). Undervisningen riktas därför in mot att skapa goda förutsättningar för skrivandet och ge uppgifter som engagerar och intresserar eleverna (Elbow, 2000; Ivanič, 2004). Goda förebilder, mycket eget skrivande och den individuella kreativa processen är centrala beståndsdelar, och det är få inslag av explicit undervisning (Blåsjö, 2010). Den främsta kritiken mot det expressiva skrivandet handlar om att eleverna får för 
lite explicit undervisning $\mathrm{i}$ både planering och grundläggande skrivfärdigheter (Blåsjö, 2010; Delpit, 2006; Ivanič, 2004). Det riskerar, enligt Delpit (2006), att leda till att framför allt elever med skrivsvårigheter eller med annan språklig bakgrund inte får den hjälp som de behöver för att utvecklas.

I den processorienterade diskursen ligger fokus på själva skrivprocessen, snarare än på skrivprodukten, vilket är en viktig skillnad från den kreativa diskursen (Ivanič, 2004). En likhet mellan de båda diskurserna är betoningen på skrivglädje, rika tillfällen till skrivande och vikten av att få skriva om det som eleven tycker är intressant (Calkins, 1995; Graves, 2003). I alla delar av skrivprocessen har eleverna möjlighet att få respons på sina texter för att sedan vidareutveckla och omarbeta dem. Det finns flera moment av explicit undervisning som främst är inriktad på själva skrivprocessen. Företrädare för den processorienterade skolan argumenterar för att det stöd som eleverna får i stavning, interpunktion med mera ska ske i samband med att eleverna skriver egna texter och inte lösryckt i separata lektioner (Calkins, 1995; Graves, 2003). Kritiker menar att den starka betoningen på processen kan göra att produkten hamnar alltför mycket i skymundan (Pritchard \& Honeycutt, 2006). En annan vanligt förekommande kritik är att eleverna får för lite undervisning i skrivstrategier och skrivkonventioner samt att endast innehållet fokuseras (Blåsjö, 2010; Graham \& Sandmel, 2011).

Genrediskursen utvecklades delvis som en reaktion på att de båda ovan beskrivna diskurserna innehöll för lite explicit undervisning (Blåsjö, 2010). Den grundar sig i systemisk-funktionell lingvistik (SFL) - en teori om språk- och språkanvändning som utvecklats av Halliday och Matthiessen (2004). De menar att språkets funktion är beroende av den sociala och kulturella kontext som det används i. Likartade texter som skapas och finns i en gemensam kulturell kontext bildar en genre, och varje genre kännetecknas av att den har ett speciellt syfte, en speciell övergripande struktur och vissa språkliga drag (Christie \& Derewianka, 2008; Gibbons, 2006; Halliday \& Matthiessen, 2004). I undervisningen bör varje genres särdrag explicit behandlas. Detta ska ske på ett genomarbetat och systematiskt sätt genom att texter både studeras och skrivs gemensamt och enskilt (Christie \& Derewianka, 2008; Gibbons, 2006; Liberg, 2013). I denna process ska eleverna få möjlighet att tillägna sig ett metaspråk om skrivande. Gibbons (2006) beskriver berättelsen som en av flera genrer. I den genren bör eleverna undervisas i dess struktur, vilken beskrivs som orientering och komplikation som avslutas med evaluering och lösning, och i dess språkliga drag (dåtid, dialog, kronologisk ordning, tidsord med mera). Kritik mot genrepedagogiken berör bland annat att genrer beskrivs som statiska, vilket ger eleverna en missvisande bild av genrer (Frankel, 2013). Enligt Fisher (2006) finns det en risk för att skrivglädjen minskar om varje genre beskrivs som fast och om läraren i alltför stor utsträckning styr och påverkar elevernas skrivande. Även Holmberg (2014) menar att det finns en fara i att se genrer som fasta. I stället går det att "tala om både typiska och alternativa drag" (Holmberg, 2014, s. 128). 
Färdighetsdiskursen kännetecknas av explicit undervisning om den tekniska sidan av skrivandet när det gäller främst stavning och grammatik (Ivanič, 2004). I diskursen om social praktik framhålls att skrivande sker i ett sociokulturellt sammanhang och att det därför är viktigt att skapa en praktik med tydliga motiv och synliga mottagare för skrivandet. Den sista diskursen är den sociopolitiska diskursen. Även i denna diskurs ses skrivande som del i ett sammanhang, men här med betoning på vilka sociala och politiska syften som skrivandet ämnar uppfylla. Där betonas också vikten av att ha ett kritiskt förhållningssätt och vara medveten om att skrivalster har en potential att påverka (Ivanič, 2004).

Ivanič (2004) menar att det är sällan en lärare undervisar utifrån endast en av diskurserna. De sex diskurserna kan och bör kombineras. Detta är något som också framkom i Yassin Falks (2017) observationsstudie av skrivundervisningen i en årskurs 3-klass. I berättelseskrivandet var främst kreativitetsdiskursen, processdiskursen och genrediskursen framträdande.

\section{Explicit och implicit undervisning}

Diskurserna skiljer sig åt avseende i vilken utsträckning de förespråkar implicit eller explicit undervisning. Den implicita undervisningen bygger på ett antagande om att eleverna utvecklar sitt skrivande genom att de möter rika litterära miljöer och får möjlighet att skriva mycket i kreativa sammanhang. Den explicita undervisningen handlar om att uttalat peka på och lyfta fram centrala delar i skrivandet och skrivprocessen. Vad som explicit undervisas om skiljer sig delvis mellan de olika diskurserna (Ivanič, 2004).

I Holmbergs (2014) studie, om undervisning i att skriva deckare på gymnasieskolan, framkommer inledningsvis starka drag av kreativitetsdiskursen. Sedan sker en närmast omärklig glidning mot genrediskursen, åtminstone när det gäller lärarens förväntningar på de texter som produceras. Holmberg menar att det blir en målkonflikt eftersom lärarnas förväntningar inte återfinns i undervisningen, utan de finns bara implicit. Hos äldre elever behöver dock inte problemet vara att eleverna inte har kunskap om de genrespecifika dragen. De har ofta mött så många olika skriftliga förebilder att de har god implicit kunskap. Däremot saknas ofta ett språk för att tala om skrivande och om texter i undervisningen, vilket påverkar de texter som skapas (Holmberg, 2014). Förekomsten av ett metaspråk skulle, enligt Holmberg (2014), möjliggöra explicita samtal om texter och dess struktur. Liknande resultat framkommer i Yassin Falks (2017) studie. I hennes fallstudie av skrivundervisning i årskurs 3 framkommer att det som fokuseras i undervisningen också får genomslag i elevernas texter. I de fall undervisningen är implicit och lärarens förväntningar är otydliga, krävs att eleverna gör fler omarbetningar av texten innan den är färdig. Yassin Falk (2017) beskriver att läraren hade förväntningar på att elevernas skrivna sagor skulle ha en viss struktur, men eftersom det inte var uttalat i undervisningen inför skrivuppgiften fick eleverna problem med sitt eget skrivande inom detta område. Liksom Holmberg (2014) framhåller Yassin 
Falk (2017) betydelsen av att ha ett metaspråk och samtala om skrivande och texter $\mathrm{i}$ undervisningen.

Blåsjö (2010) påtalar att det har skett ett skifte från implicit till mer explicit skrivundervisning. Den explicita undervisningen har också stöd i forskningen (Graham et al., 2016). Riktade insatser i olika typer av interventioner har visat sig ge goda resultat på elevernas lärande (Graham et al., 2016).

\section{Interventionsstudier om undervisning $i$ berättelseskrivande}

Det finns flera studier, med lite olika teoretiska utgångspunkter, som fokuserar på hur elevers skrivande kan förbättras genom explicit skrivundervisning. Oavsett utgångspunkt framgår det att undervisningen behöver utgå från elevernas nuvarande nivå och specifikt riktas mot de utmaningar som eleverna har i sitt skrivande. Graham (2006) har gjort en kvantitativ metaanalys av flera interventionsstudier som fokuserar på strategiundervisning $\mathrm{i}$ att skriva berättande och beskrivande texter $\mathrm{i}$ grundskolan och gymnasieskolan. Resultatet av metaanalysen visar att undervisning av planerings- och revideringsstrategier ger signifikant bättre resultat på elevernas skrivalster jämfört med ordinarie undervisning. De framgångsrika strategierna fokuserar dels på strategier för självreglering, dels på undervisning i berättelsers uppbyggnad och komponenter.

Case och McKeough (1989) och Jarvey, McKeough och Pyryt (2008) har gjort interventionsstudier för att förbättra elevers förmåga att skapa berättelser, ur ett kognitivt utvecklingsperspektiv som är baserat på Piagets stadieteori. I båda studierna har författarna haft som utgångspunkt att undervisningen bör rikta in sig mot elevernas nästa åldersmässiga utvecklingsnivå. Detta innebär att undervisningen explicit hanterar berättelsens struktur och karaktärsbeskrivningarna på det sätt som är typiskt för nästa kognitiva utvecklingsnivå (det vill säga åldersnivån över elevens nuvarande ålder). ${ }^{3}$ Båda dessa studier visade att denna typ av undervisning gjorde att eleverna som deltog i interventionerna förbättrade sin förmåga att skapa berättelser mer än de som deltog i traditionell undervisning.

I en interventionsstudie av Saddler och Asaro (2007) fick elever i årskurs 6 med skrivsvårigheter undervisning i berättelsens viktigaste komponenter. Eleverna fick lära sig planeringsstrategier för att arbeta med karaktär, tid, plats, problem och lösning. De berättelser som eleverna skrev förbättrades märkbart av undervisningsinsatsen. De var längre och de innehöll fler av berättelsens komponenter. Trots det lade eleverna inte ner mer tid på planering efter interventionen än före. Andra studier har visat att det är svårt att få yngre elever att lägga tid på planering av sitt skrivande innan de börjar skriva (McCutchen, 2006). Dunn och Finley (2010) och

\footnotetext{
${ }^{3}$ Detta sätt kan tyckas ha likheter med den proximala utvecklingszonen (ZPD), som beskrivs av Vygotskij (1934/2001). ZPD innebär att eleven kan mer med stöd av en kunnigare person än vad eleven klarar självständigt. Undervisningen bör därför, enligt Vygotskij, ligga precis över den nivå där eleven befinner sig. I de beskrivna interventionsstudierna är dock utgăngspunkten de kognitiva stadier som Piaget har beskrivit. Dessa stadier appliceras på elevernas åldersnivå, inte på en individuell analys av enskilda elevers kunnande.
} 
Montague och Leavell (1994) har i sina studier kommit fram till att texterna blir bättre i de fall elever, särskilt de med skrivsvårigheter, verkligen lär sig och använder en planeringsmall innan de börjar skriva. Detta antas bero på att eleverna då lättare får med berättelsens viktigaste delar, eftersom de inte behöver hålla det $\mathrm{i}$ huvudet samtidigt som skrivandet sker. McCutchen (2006) lyfter dock fram ett problem med planeringsstöd i skrivundervisningen, i detta fall för barn i 10-årsåldern. Han påtalar att när olika typer av planeringsstöd används som tydligt inslag i undervisningen, i form av bland annat planeringsramar, har många 10-åringar svårt att föra kortfattade anteckningar, vilket resulterar i att det blir liten skillnad mellan deras planering och deras färdiga produkt.

Andra studier har särskilt fokuserat på att eleverna ska utveckla sin kreativa sida för att kunna utveckla sin förmåga att skriva berättelser. I Bayat (2016) undersöks hur elever i årskurs 4 påverkas av ett kreativt skrivutvecklingsprogram, där muntligt förarbete och ett särskilt fokus på kreativitet och idégenerering var viktiga komponenter. Totalt ingick 88 elever i studien, varav hälften i en kontrollgrupp. Kontrollgruppen fick ordinarie skrivundervisning och testgruppen följde det kreativa utvecklingsprogrammet i stället. Båda gruppernas texter bedömdes sedan utifrån sex kriterier för kreativitet. Resultaten visar att undervisningens fokus på idéskapande och på hela skrivprocessen gjorde att testgruppen skrev signifikant bättre berättelser, avseende kreativitet, än kontrollgruppen. Enligt Bayat (2016) beror detta på att eleverna uppmuntrades att på olika sätt utforska sina idéer och att dramatiseringar och andra övningar skapade ett öppet och kreativt klimat. Vidare framhåller Bayat att individer visserligen har olika lätt att komma in i ett kreativt flöde, men att det är en förmåga som går att påverka genom undervisningen. I en forskningsöversikt av Bardot et al. (2012) framkommer att lärare vanligtvis inte lägger upp undervisningen för att eleverna ska utveckla sin fantasi och sin kreativa förmåga, trots att de anser att den förmågan är viktig. En möjlig orsak till detta kan, enligt Bardot et al., vara att lärarna ser den kreativa förmågan som medfödd och som en inneboende talang, snarare än något som går att påverka.

\section{Att utveckla barns berättelseskrivande}

Denna genomgång av tidigare forskning visar att det behövs flera olika ingångar för att utveckla elevers kunnande när det gäller att skriva berättelser. Det narratologiska perspektivet bidrar med kunskap om berättelsers struktur och uppbyggnad baserat på deras story och diskurs. Perspektivet bygger på analyser av kompetenta skribenter, det vill säga alster från erkända författare. Begreppen från narratologin är till hjälp även vid en analys av barns berättelser, men de behöver kombineras med kunskap om barns skrivutveckling. Flera studier har kartlagt barns berättelser utifrån hur de byggs upp i olika åldrar. Denna avhandling kan komplettera denna typ av studier av barns berättelser, eftersom forskningen i föreliggande avhandling riktar in sig på att analysera elevers skilda sätt att ta sig an berättelseskrivande vid 
en särskild ålder. Med detta som grund framkommer också vilka aspekter av berättelseskrivande som behöver göras urskiljningsbara i undervisningen. Resultaten blir därför undervisningsnära.

Tidigare forskning visar att undervisningsmetoder som explicit synliggör planeringsstrategier, berättelsens komponenter och/eller berättelsers uppbyggnad påverkar elevers skrivande positivt. De beskrivna metoderna har i olika utsträckning varit förankrade i pedagogiska och didaktiska teorier. I föreliggande avhandling kombineras ämnesdidaktiskt forskningsresultat med användandet av en pedagogisk teori, nämligen variationsteorin. Variationsteorin beskrivs i nästa kapitel. 


\section{VARIATIONSTEORI}

Variationsteorin beskriver vissa grundläggande förutsättningar för lärande och den kan användas som både analysredskap och designredskap vid undervisningsnära forskning, vilket är fallet även i denna avhandling.

Grundläggande i variationsteorin är att lärandet är intentionellt; vi lär oss alltid något (Marton \& Booth, 2000; Marton, 2015). Därför blir det som ska läras centralt. Det avgränsade lärandeinnehållet och den förmåga som lärarna vill att eleverna ska lära sig benämns som lärandeobjekt (Marton, 2015; Lo, 2012; Runesson, 2017). Lärandeobjektet är alltså det kunnande som eleverna ska få möjlighet att utveckla genom undervisningen, till exempel att skriva berättelser med ett välutvecklat händelseförlopp. Carlgren (2015) menar att "lärandeobjekten är lärarens kunskapsobjekt" (s. 142). De är dynamiska och står i relation till den specifika elevgrupp som undervisas och det är i lärandeobjektet som den ämnesdisciplinära kunskapen realiseras i klassrummet. När eleverna ska få möjlighet att införliva ett nytt lärandeobjekt appliceras teorins grundprincip: människor lär sig nytt genom att se skillnader och inte genom att se likheter (Lo, 2012; Marton, 2015; Marton \& Pang, 2013).

Variationsteorin har sina rötter i fenomenografi. Det är en metodologisk ansats som växte fram i Sverige under 1970- och 80-talet (Marton, 1981) och som beskrivs närmare nedan. Därefter ges en fördjupning i två bärande idéer i variationsteorin, nämligen kritiska aspekter och variationsmönster. Kapitlet avslutas med en beskrivning av variationsteorin i ett svenskdidaktiskt sammanhang och av teorins relation till föreliggande avhandling.

\section{Fenomenografi}

Fenomenografin intresserar sig för kvalitativt skilda sätt att erfara världen (Marton, 1981; Marton \& Booth, 2000; Svensson, 1997). Syftet i en fenomenografisk analys är att beskriva världen så som den upplevs av andra (Marton, 1981). Det benämns som andra ordningens perspektiv och det innebär att forskaren försöker att förstå handlingar och utsagor utifrån den andres logik (Marton, 1981; Pang \& Ki, 2016). Strävan är alltså att se fenomenet ur elevens perspektiv. Det är en skillnad mot det som kallas för första ordningens perspektiv, där syftet med forskningen är att beskriva världen så som den är (till exempel naturvetenskaplig forskning).

En grundtanke inom fenomenografi är att det på en kollektiv nivå finns ett begränsat antal kvalitativt skilda sätt att uppfatta en företeelse, ett fenomen eller ett lärandeobjekt (Marton, 1981). Begreppet uppfattningar innebär i detta sammanhang inte detsamma som åsikter. Istället är det hur ett fenomen eller lärandeobjekt 
erfars, urskiljs och upplevs. Det handlar om spontana förhållningsätt och angreppssätt till det undersökta fenomenet. Uppfattningarna är inte bundna till individen, vilket gör att en och samma individ kan växla mellan olika uppfattningar.

De ursprungliga fenomenografiska studierna bidrog med beskrivningar av kvalitativt skilda uppfattningar av olika slags kunskapsinnehåll, se till exempel Marton och Säljö (1976) om lärstrategier och Hounsell (1984) om historiestudenters essäskrivande. I senare studier har fenomenografi även använts för att beskriva ett kunnande, se till exempel Ahlstrand (2014) om närvaro på scenen och Nyberg (2014) om rörelsekunnandet $i$ ett danssteg. Dessa studier baseras på ett antagande om att olika sätt att se, göra eller vara är kopplat till olika sätt att kunna något (Carlgren, Ahlstrand, Björkholm \& Nyberg, 2015).

Fenomenografi har använts för att beskriva kvalitativt skilda uppfattningar av ett fenomen. Variationsteorin växte fram ur ett behov av att inte bara beskriva olika uppfattningar, utan att också kunna förklara hur lärande går till och hur elever med olika uppfattningar kan få möjlighet att utveckla mer komplexa sätt att erfara ett lärandeobjekt (Marton, 2015; Runesson, 2017). I variationsteorin har två centrala delar tillkommit: kritiska aspekter och variationsmönster.

\section{Kritiska aspekter}

Kritiska aspekter är ett centralt begrepp inom variationsteori. Det bygger på ett antagande om att människor urskiljer olika aspekter av de företeelser, fenomen och lärandeobjekt som de möter (Marton \& Booth, 2000). Hur helheten uppfattas beror på vilka aspekter som är urskilda.

Alla fenomen rymmer en mängd aspekter, men alla är inte nödvändiga för att definiera själva fenomenet (Marton, 2015). En berättelse är en berättelse oavsett om den är skriven med bläck eller blyerts eller om den är skriven på svenska eller engelska, så aspekterna layout och språk är alltså inte avgörande för att det ska vara en berättelse. Andra aspekter är däremot nödvändiga för att urskilja att det är just en berättelse. Exempelvis har en berättelse en viss struktur och innehåller vissa element, såsom karaktärer och händelser (Chatman, 1978). De aspekter som är nödvändiga att urskilja för att utveckla ett visst kunnande, men som ännu inte har urskilts av den lärande, benämns som kritiska aspekter (Marton, 2015). Kritiska aspekter är därför relaterade till den aktuella elevgruppen. De beskriver vad den lärande behöver urskilja eller erfara på för att utveckla det aktuella kunnandet.

Kritiska aspekter har uttolkats och använts på flera sätt. Pang och Ki (2016) menar att kritiska aspekter i vissa sammanhang har tolkats som likvärdigt med de viktigaste aspekterna av ämnesinnehållet och hur det beskrivs i ämnesdisciplinen. De anser att denna uttolkning är problematisk, eftersom kritiska aspekter alltid måste stå i relation till elevers olika sätt att erfara lärandeobjektet, vilket är något som även Marton (2015) påtalar. Enligt Runesson (2017, s. 49-50) är "kritiska aspekter något dynamiskt och framväxande, snarare än en statisk lista över olika ämnesinnehåll som eleverna behöver lära sig”. De är relationella och finns mellan 
den lärande och det som lärs. Därför bör, enligt Pang och Ki (2016), en fenomenografisk ansats vara utgångspunkten i sökandet efter kritiska aspekter. Det är i jämförelsen mellan olika sätt att uppfatta något som det går att hitta de kritiska aspekterna. Jämförelsen bygger på kvalitativa skillnader mellan olika elevuppfattningar och även på skillnader mellan elevuppfattningar och den uppfattning som undervisningen strävar mot.

\section{Variationsmönster - att synliggöra kritiska aspekter i undervisningen}

Marton (2015) menar att det endast är möjligt att urskilja aspekter som varierar. Varje urskiljbar aspekt är därför också en dimension av variation. Till exempel är aspekten färg en dimension av variation eftersom det finns olika färger. De olika färgerna (till exempel röd, grön, gul och blå) benämns som värden på den dimensionen. Att vi bara kan urskilja det som varierar är något som även påverkar lärandet. En grundtanke inom variationsteorin, som bygger på detta antagande, är att vi lär oss genom att erfara skillnader, inte likheter (Marton, 2015). Om läraren medvetet använder en variation av innehållet ökar därför elevernas möjlighet till lärande (Lo, 2012; Marton, 2015). I grunden handlar det om att variera den aspekt som ska göras urskiljningsbar och samtidigt hålla andra aspekter invarianta (det vill säga konstanta). Detta erhålls genom att applicera olika variationsmönster: kontrast, generalisering och fusion (Marton, 2015).

Kontrast används för att eleverna ska kunna urskilja en aspekt som de ännu inte har urskilt, det vill säga en kritisk aspekt. Detta sker när en dimension av variation öppnas, när två värden kontrasteras. Det innebär att ett visst värde jämförs med ett annat, vilket gör att aspekten och värdena framträder samtidigt (Marton, 2015). Om det till exempel är önskvärt att eleverna ska urskilja aspekten genre kan olika genrer kontrasteras mot varandra, exempelvis argumentation mot fakta. Då är dessa båda genrer värden på en dimension av variation som handlar om genrer. På så sätt synliggörs både den övergripande aspekten (genre) och specifika värden (argumentation och fakta). För att kontrasten ska framträda tydligt behöver andra aspekter vara invarianta (Marton, 2015). Detta skulle till exempel kunna innebära att en argumenterande text om skolmaten ställs mot en faktatext om skolmaten. Då är det övergripande innehållet invariant. I exemplet bör även textlängd och layout vara invarianta, eftersom den fokuserade aspekten (det vill säga genre) då framträder tydligare. Det som varieras är alltså enbart genrens betydelse för hur texten om skolmat skulle framställas.

När en aspekt är urskild behöver den generaliseras (Marton, 2015). I denna fas undersöks gränserna för aspekten. Då hålls den fokuserade aspekten invariant och andra aspekter varierar. Om vi till exempel vill undersöka faktagenren gäller det att separera ut aspekter som inte påverkar vilken genre det är. Det skulle kunna innebära att läraren visar olika typer av faktatexter. På så sätt framträder att det är 
en faktatext, oavsett om den handlar om skolmat eller om björnar. Även vid generalisering varieras endast en aspekt $i$ taget, men då är det i stället de aspekter som ska bortses från som undersöks systematiskt. Då ges flera exempel på samma sak. Här är fokus på likheter. En förutsättning för generalisering är att aspekten redan är urskild.

I den sista fasen beaktas lärandeobjektet som en helhet igen. Då sammanförs alla aspekter som tidigare har analyserats i det som Marton (2015) benämner som fusion. I exemplet med genrer innebär det att både den fokuserade aspekten (genrer) och andra aspekter (innehåll och layout) varierar. Genom att gradvis göra helhetsbilden mer och mer komplex, synliggörs hur kritiska aspekter påverkar varandra och till helheten.

En överblick över lärandeprocessen innebär att den lärande börjar med att se lärandeobjektet som en odelbar helhet (Marton, 2015). Aspekter av lärandeobjektet kan dock göras urskiljningsbara via kontrast. Via generalisering undersöks sedan vilka aspekter som kan bortses från. Avslutningsvis sammanförs aspekterna till en helhet igen, via fusion. Sammanfattningsvis beskriver Marton (2015) lärandeprocessen så här: "moving the experience from an undifferentiated whole, through differentiation and integration, towards a differentiated and integrated whole" (s. 53).

\section{Variationsteorin i skrivundervisning}

Det finns ett fåtal publicerade studier där variationsteorin har använts som designredskap för att lägga upp undervisning i skrivande. Cheung (2005) genomförde en interventionsstudie utifrån variationsteoretiska antaganden i Hong Kong med syftet att undersöka hur den kreativa förmågan hos elever i årskurs 3 kunde förbättras. Cheung skapade ett eget analysverktyg och bedömde elevernas texter baserat på flexibilitet, originalitet och förmågan att skapa idéer. Två grupper deltog i interventionen, varav en fungerade som kontrollgrupp. I kontrollgruppen fick eleverna ordinarie skrivundervisning. Interventionen fokuserade på fyra områden: (1) kronologin i berättelser, (2) olika möjliga lösningar på problem i berättelser, (3) händelser som ordnas i tidsordning och (4) karaktärsbeskrivningar. Designen på lektionerna byggde på att skapa en variation som synliggjorde kritiska aspekter. Cheung (2005) beskriver att de elever som deltog i interventionen skrev mer innehållsrika, varierade och originella berättelser efter interventionen än de elever som ingick i kontrollgruppen.

Runesson och Gustavsson (2012) har i en svensk studie provat om det går att, i en ny kontext med en ny lärargrupp, använda resultat från tidigare studier där variationsteorin har använts. De båda forskarna lät en lärargrupp utgå från resultatet i Cheungs studie när de skulle göra en egen studie om kreativt skrivande. Enligt författarna kunde lärarlaget dra lärdom av Cheungs resultat i sin egen studie, även om deras elever delvis hade andra svårigheter och de därför valde ett lite annat lärandeobjekt. 


\section{Variationsteorin i denna avhandling}

Variationsteorin har flera funktioner i avhandlingen. I licentiatuppsatsen används teorin som både analys- och designredskap och i artikel I är den ett av analysredskapen. I artikel II och III har i stället teorins funktion i forskningsprocessen studerats.

Valet av variationsteorin som teoretisk ansats motiveras av i huvudsak tre skäl. Det första skälet handlar om att huvudintresset i denna avhandling är undervisning och elevers lärande. Variationsteorin innehåller antaganden och begrepp som gör det möjligt att undersöka lärandeobjektet och elevernas kunnande. Dessutom erbjuder teorin tankemodeller för att designa undervisning. Det andra skälet är att teorin har prövats i ett flertal studier, till exempel Cheung (2005) och Marton \& Pang (2013). I dessa interventionsstudier ${ }^{4}$ med kontrollgrupper har det framkommit att elevernas lärande ökar när variationsteoretiska principer används vid designandet av undervisningen. Det tredje skälet är att teorin i flera studier har använts tillsammans med undervisningsutvecklande forskningsansatser, särskilt tillsammans med Learning study (Runesson, 2017). Det är också den metod som använts i denna avhandling.

Variationsteorin lämpar sig alltså för att undersöka och designa innehållets behandling i undervisningen. Teorin gör däremot inte anspråk på att ge redskap för att behandla andra processer som också är viktiga i ett undervisningssammanhang, till exempel ledarskap och motivation. Till det behövs andra teorier och annan forskning. Variationsteorin passar att kombineras med teorier som på något sätt berör kunnandets karaktär eller innehållets behandling i undervisningen. I den här avhandlingen används därför ämnesdisciplinära teorier i form av narratologiska teorier som stöd. Dessutom relateras till skrivdidaktiska teorier och teorier om skrivutveckling.

\footnotetext{
${ }^{4}$ Interventionsstudier i skolmiljö påverkas av en mängd variabler som är svåra att kontrollera, vilket behöver beaktas i resultaten. Bara det faktum att ett särskilt område fokuseras i undervisningen kan göra att elevernas resultat förbättras. I Cheungs (2005) studie hade kontrollgrupperna ordinarie undervisning. I Marton och Pangs (2013) studie ställdes däremot två interventioner mot varandra. Där jämfördes hur elevers lärande påverkades när en Learning study (med variationsteori) och en Lesson study (utan variationsteori) genomfördes. Resultaten blir då mer trovärdiga eftersom metoderna var likadana och endast teorianvändandet skilde sig åt.
} 


\section{ATT UNDERSÖKA OCH UTVECKLA ETT KUNNANDE}

Kunskap om hur kunnande i berättelseskrivande kan göras undervisningsbart är centralt för lärare som undervisar inom området. Det handlar om kunskap om vad kunnandet innebär och om hur undervisningen kan möjliggöra att eleverna utvecklar kunnandet. I det här kapitlet behandlas förutsättningar som kan möjliggöra att kunskap om undervisning och lärande genereras.

Kapitlet inleds med en beskrivning av undervisningsutvecklande forskning, det vill säga forskning som undersöker hur undervisning kan möjliggöra att ett kunnande utvecklas, vilket kan ses som en slags praktiknära forskning. I nästa del behandlas Learning study, som ett exempel på denna typ av forskning. Efter det tas tre komponenter upp som är centrala i Learning study, men som även har betydelse i andra liknande forskningsansatser. Den första komponenten handlar om forskningsintresset, och då behandlas att forskningen riktar in sig mot ett specifikt kunnande. Avsnittet benämns därför "kunnandet i fokus". Därefter beskrivs den andra komponenten, vilken är lärarerfarenhetens betydelse i forskningsprocessen. Avslutningsvis behandlas aspekter som berör användande och generering av teori i praktiknära forskningsansatser.

\section{Undervisningsutvecklande forskning}

Undervisningsutvecklande forskning har som syfte att bidra med kunskap om hur undervisning kan öka elevernas lärande. Carlgren (2017) beskriver denna typ av forskning som kollaborativ, intervenerande och iterativ. Forskningen är kollaborativ eftersom den sker i ett samarbete mellan lärare och forskare, och ibland ryms båda kompetenserna i en och samma person. Att forskningen är intervenerande innebär att olika undervisningsupplägg testas och analyseras. Carlgren (2017) uttrycker det på följande sätt: 'I utvecklingsforskning studeras alltså inte den praktik som pågår 'naturligt', utan istället olika processer i samband med att mer eller mindre teorigrundade utformningar av undervisningen införs." (s 179). Det sista kännetecknet är iterativitet. Det innebär att förloppet är cykliskt. En intervention testas, för att sedan analyseras, revideras och testas igen.

Även Morris och Hiebert (2011) framhåller att det är viktigt att generera forskning som handlar om lärares kärnuppdrag, det vill säga undervisning. De menar att sådan forskning är relevant för lärare och att det bör finnas former inom professionen för att sprida de resultat som den genererar. Morris och Hiebert (2011) lyfter fram några kännetecken för denna typ av forskning, som liknar det Carlgren beskriver. För det första menar de att de problem som beforskas ska delas av alla som deltar i forskningsprocessen, där både lärare och forskare bör ingå. Det bör vara en gemensam problemlösningsprocess där alla medforskare har som mål att 
lösa samma problem. För det andra ska studierna bygga på små, djuplodande tester, som gärna testar en intervention iterativt. Morris och Hiebert (2011) motiverar detta med att detaljer spelar roll i undervisningen och att sådana studier överbygger gapet mellan teori och praktik. För det tredje ska den kunskapsprodukt som skapas växa fram i en kollektiv process, där deltagarna har olika kompetens och också respekt för varandras kunskaper och idéer.

Det har under de senaste årtiondena vuxit fram forskningspraktiker som har ovanstående kännetecken. Ibland beskrivs de under samlingsnamnet aktionsforskning, men även uttryck såsom klinisk forskning och praktiknära forskning har använts. Morris och Hiebert (2011) framhåller att den japanska skolutvecklingsmodellen Lesson study är ett gott exempel på hur denna typ av forskning skulle kunna genomföras. I en Lesson study arbetar lärare tillsammans i en cyklisk process (Lewis, 2009). Under processen planeras, genomförs, analyseras och revideras en lektion. Enligt Morris och Hiebert (2011) innehåller Lesson study de komponenter som är centrala för forskning som kan generera resultat med hög relevans för undervisningspraktiken. Lesson study utgår från djupanalyser av en lektion, och är en form av djuplodande småskaliga studier. Resultatet av en Lesson study kan bestå av lektionsplaneringar som kompletteras med kommentarer. Dessa kommentarer ska beskriva och motivera varför undervisningsupplägget fungerar och bidra med lokala teorier om undervisning (Morris \& Hiebert, 2011). En metod som har flera likheter med Lesson study är Learning study, vilken beskrivs i nästa avsnitt.

\section{Learning study}

Learning study innebär en systematisk undersökning av hur undervisning kan möjliggöra att eleverna utvecklar ett avsett kunnande (Carlgren et al., 2017). Kunnandet, som benämns som lärandeobjektet, är således i fokus under hela processen. Learning study används både som forskningsmetod och som skolutvecklingsmodell. Modellen utvecklades i ett samarbete mellan forskare i Sverige och Hong Kong i början av 2000-talet, inspirerat av Lesson study. Den har samma cykliska förlopp och kollaborativa inslag som Lesson study, men i en Learning study används alltid en teori om lärande $i$ hela processen, som både design- och analysredskap (Runesson, 2017). Variationsteorin har utvecklats tillsammans med Learning study och är den teori som oftast har använts (Lo, 2012), vilket gör att begrepp såsom lärandeobjekt och kritiska aspekter är framträdande även i Learning studyprocessen.

I den här avhandlingen är Learning study centralt ur flera perspektiv. Modellen har använts som forskningsmetod (framför allt i Thorsten, 2014), och dessutom har användandet av den analyserats (i Thorsten, 2015 och Thorsten, 2017). Nedan ges en övergripande beskrivning av forskningsprocessen i Learning study. I metodkapitlet beskrivs genomförandet av den specifika Learning study som är utgångspunkten i föreliggande avhandling. 


\section{Learning study-processen}

I en Learning study samarbetar vanligen en forskare (eller handledare vid skolutveckling) med en grupp lärare som undervisar i samma ämne och samma åldersgrupp (Carlgren et al., 2017; Lo, 2012; Marton \& Runesson, 2015; Pang \& Marton, 2003). Forskningsgruppen utforskar undervisningen av ett lärandeobjekt. Karakteristiskt i utforskandet är iterativiteten. Det går med andra ord att beskriva Learning study som bestående av flera delstudier, där varje delstudie bygger på en analys av den förra. I Learning study-sammanhang brukar varje sådan delstudie benämnas som cykel. Processen i en Learning study beskrivs i figur 2 .

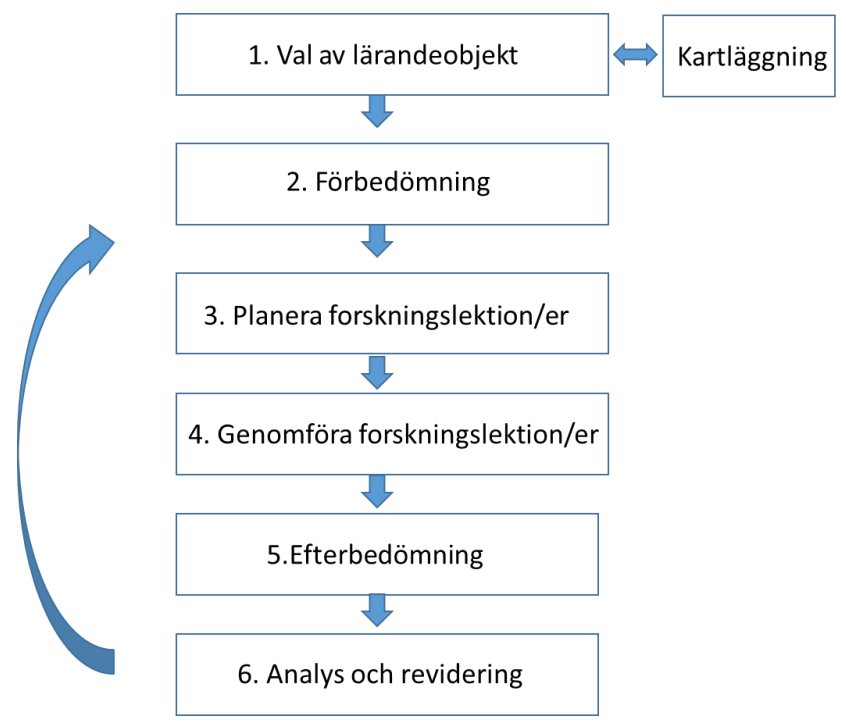

Figur 2. Modell över Learning study-processen, inspirerad av Carlgren et. al. (2017, s. 21).

Processen består av sex steg, varav de fem sista stegen upprepas i varje cykel (Carlgren et al., 2017). Samtliga steg genomsyras av en diskussion om och analys av lärandeobjektet och dess kritiska aspekter.

Inledningsvis väljer gruppen ett lärandeobjekt (Carlgren et al., 2017; Lo, 2012), företrädesvis något som lärarna tycker är svårt att undervisa om och som eleverna har svårt att lära sig. I vissa fall görs därefter en förstudie eller kartläggning. Då undersöks hur en elevgrupp erfar lärandeobjektet. Syftet är att få ökad kunskap om lärandeobjektet och vilka aspekter som kan tänkas vara kritiska. I detta första steg diskuteras lärandeobjektet och möjliga kritiska aspekter. Gruppens erfarenhetsbaserade kunskap, ämnesdidaktisk litteratur, ämneslitteratur och läroplaner används som en resurs $i$ hela processen. Lärandeobjektet och de kritiska 
aspekterna är i detta läge endast preliminärt definierade, eftersom de ännu inte har utforskats i den elevgrupp som ska undervisas (Carlgren et al., 2017).

Därefter genomförs någon form av förbedömning/förtest (Carlgren et al., 2017; Lo, 2012). Syftet med detta moment är dels att få kunskap om elevernas kvalitativt skilda sätt att förstå och hantera lärandeobjektet, dels att få något att jämföra med efter lektionen, för att se vilken skillnad undervisningen har gjort. I detta läge påbörjas en precisering av både lärandeobjektet och de kritiska aspekterna.

I det tredje steget planeras forskningslektionen/lektionerna. När Learning study används i skolutvecklingssammanhang är oftast endast en lektion i fokus, men i forskningssammanhang kan det ibland vara en kortare lektionsserie, vilket var fallet i föreliggande studie. Lektionerna planeras gemensamt av forskningsgruppen. Variationsteorin används för att skapa variationsmönster där de kritiska aspekterna synliggörs. Syftet är att göra de kritiska aspekterna tillgängliga för eleverna (Carlgren et al., 2017).

I nästa steg genomförs forskningslektionen/lektionerna. En lärare genomför lektionen, ofta (men inte alltid) i sin egen klass. De andra lärarna är med och observerar, och ofta filmas lektionen (Carlgren et al., 2017). Efter lektionens/lektionernas genomförande undersöks återigen elevernas kunnande (Carlgren et al., 2017; Lo, 2012). Denna efterbedömning är likadan eller nästan likadan som förbedömningen. Syftet är att undersöka vad eleverna har lärt sig på lektionen.

Det sista steget består av analys och revidering. Då analyseras för- och efterbedömningen i relation till varandra och i relation till lektionen/lektionerna (Carlgren et al., 2017; Lo, 2012). På så sätt blir det möjligt att få syn på vilka svårigheter som kvarstår och vad som behöver utvecklas vidare. Via lektionsanalysen går det också att identifiera nya kritiska aspekter. Analysen ligger till grund för en revidering av både lärandeobjektet och de kritiska aspekterna. De är dynamiska och specificeras i hela processen (Carlgren et al., 2017; Mårtensson, 2015). Efter detta avslutande steg börjar förloppet om igen med en ny cykel.

\section{Learning study som forskningsansats och skolutvecklingsmodell}

Carlgren et al. (2017) menar att det finns en skillnad i syfte när Learning study används som skolutvecklingsmodell respektive forskningsansats. När Learning study används som skolutvecklingsmodell är syftet att utveckla undervisningen på den egna skolan och att utveckla lärarnas professionella kompetens. Som forskningsansats är syftet att generera kunskap som är relevant för hela lärarprofessionen. I licentiatuppsatsen användes Learning study som forskningsansats. Även när den kunskapsgenererande processen är i fokus är det vanligt att lärarna som deltar i studien samtidigt utvecklas professionellt (Pang \& Ling, 2012; Vikström, Kullberg \& Runesson, 2017).

Lärarnas professionella utveckling i Lesson study respektive Learning study liknar delvis varandra. Enligt Dudley (2013), som har studerat processen i Lesson 
study, sker utvecklingen genom att lärarnas antaganden och idéer synliggörs och utmanas. Det leder till att den ämnesdidaktiska kompetensen fördjupas. I en Learning study läggs ytterligare en aspekt till, eftersom en teori används i hela processen. Både Elliott (2012) och Gómez, Sérvan Núnez, Pérez Gómez och Trapera (2015) framhåller att teorianvändandet har stor betydelse, eftersom teorin bidrar till att utmana befästa föreställningar om undervisning och lärande genom att lärarnas egna antaganden synliggörs i mötet med en teori. Dessutom erbjuder variationsteorin alternativa förhållningssätt och förklaringsmodeller till relationen mellan undervisning och lärande. Mårtenssons (2015) studie av matematiklärare och Sädbom Florins (2015) studie av samhällskunskapslärare visar att teorianvändandet i Learning study utvecklar lärarnas ämneskunskap likväl som deras ämnesdidaktiska kunskap. Mårtensson (2015) beskriver hur lärare förändrade sin initiala kunskap om lärandeobjektet och de kritiska aspekterna när de analyserade elevernas kunnande. De uppmärksammade detaljer i hur innehållet tillgängliggörs i undervisningen som har avgörande betydelse för elevers lärande. Både lärandeobjektet och de kritiska aspekterna gick från att vara vagt beskrivna på en övergripande nivå till att bli mer specificerade och exakt beskrivna (Mårtensson, 2015). Holmkvist (2011) påvisar att det är inte bara kunskapen om det specifika lärandeobjektet som ökar när lärare deltar i Learnings study. I en undersökning av engelsklärares process $i$ en Learning study framgår det att användandet av variationsteori gjorde att lärarna fick med sig teoretiska redskap som de sedan kunde använda generellt $\mathrm{i}$ undervisningen.

Både Lesson study och Learning study leder således till flera vinster rörande lärares individuella professionella utveckling. Lewis (2009) menar att deltagandet i denna typ av process dessutom möjliggör en kollegial kunskapsutveckling, som kan påverka hela skolors arbetssätt. Resultaten som framkommer behöver dock inte stanna på den egna skolan (Morris \& Heibert, 2011). En Learning study kan ge ett ämnesdidaktiskt bidrag som är intressant även utanför den specifika kontext där studien genomfördes (Marton \& Runesson, 2015; Pang \& Ling, 2012; Vikström et al., 2017). Nedan beskrivs vilken typ av ämnesdidaktiskt bidrag som möjliggörs genom metodens fokus på ett lärandeobjekt.

\section{Kunnandet i fokus}

I en Learning study fokuseras alltid ett lärandeobjekt (Lo, 2012). Centralt blir därmed det ämneskunnande som eleverna ska ges möjlighet att utveckla. I denna avhandling är det specifika ämneskunnandet att skriva berättelser med ett välutvecklat händelseförlopp. För att eleverna ska utveckla ämnesspecifika kunnanden krävs att läraren har ämneskunskap, ämnesdidaktisk kunskap och en klar bild över vilket 
kunnande som är önskvärt att eleverna utvecklar. ${ }^{5}$ Att läraren är klar över vad eleverna ska lära sig, kan tyckas självklart. Trots det finns flera metoder och teorier som inte har ett innehållsligt fokus på samma sätt som Learning study och variationsteorin (Runesson, 2017). De kan snarare adressera frågor om till exempel interaktion eller ledarskap i klassrummet.

Vikten av att läraren har klart för sig vad eleverna ska lära sig påtalades redan av Dewey (1902/2004). Dewey menade att läraren behöver veta både vad eleverna har för vardagsförståelse av ett fenomen och vilken förståelse undervisningen ska sträva mot. För det krävs en god ämneskunskap hos läraren. En lärare har dock ett annat förhållningssätt till ämnesinnehållet än en vetenskapsman. Dewey (1902/2004) menar att för vetenskapsmannen är ämnesstoffet en utgångspunkt för vidare studier och frågeställningar inom ämnet. Läraren, däremot, ska inte öka kunskapen inom ämnesdisciplinen. I stället är lärarens uppgift att göra de vetenskapliga beskrivningarna, så som de ser ut nu, tillgängliga för eleverna. Dewey (1902/2004, s.119) uttrycker det som att ämnesstoffet behöver "psykologiseras", så att eleverna kan ta till sig stoffet med utgångspunkt i sina tidigare erfarenheter. Dewey kan ses som en tidig förespråkare när det gäller skillnaden mellan ämnesdisciplinär och ämnesdidaktisk kunskap (även om han inte använder just dessa benämningar). Senare forskning, av bland annat Shulman (1986; 1987), har fördjupat kunskapen om vad lärare behöver kunna för att undervisa om ett specifikt innehåll.

\section{Ämnesdidaktisk kunskap - PCK}

Shulman $(1986 ; 1987)$ intresserade sig för vilka olika slags kunskaper en lärare behöver ha. Han menade att det är en förenkling att se lärarkunskapen som bestående av endast ämneskunskap och allmänpedagogisk kunskap. Den mest centrala lärarspecifika kunskapen handlar om hur olika ämnesinnehåll kan tillgängliggöras för eleverna. Denna typ av kunskap benämns av Shulman (1986) som pedagogical content knowledge, $P C K$, eller ämnesdidaktisk kunskap. Det gäller alltså kunskap om hur undervisningen kan möjliggöra att eleverna utvecklar ett avsett kunnande. I PCK ingår således kunskap om hur ämnesinnehållet ska organiseras och presenteras, men också kunskap om vilka ämnesområden som är särskilt utmanande för elever, vilka missuppfattningar som är vanliga, hur dessa kan överbryggas etcetera (Shulman, 1986; 1987).

Shulman (1986) beskriver PCK som en aspekt av de ämneskunskaper som lärare behöver. De andra aspekterna är de ämnesdisciplinära kunskaperna och kunskaper om ämnets framskrivning i läroplanen. Den ämnesdisciplinära kunskapen bygger på de ämnesdiscipliner som skolämnena är relaterade till. En lärare som

\footnotetext{
${ }^{5}$ Naturligtvis krävs även vissa mer allmändidaktiska kunskaper, såsom gott ledarskap och kunskap om grupprocesser, men eftersom avsnittet tar upp innehållsliga aspekter av undervisningen är det endast dessa som belyses här.
} 
ska undervisa i berättelseskrivande behöver till exempel ha kunskaper inom litteraturvetenskap. Detta inbegriper kunskap om vad som ses som ett vedertaget förhållningssätt och som god kvalitet inom ämnet. Den ämnesdisciplinära kunskapen utgör basen för PCK, för utan en god ämneskunskap är det inte möjligt att lägga upp undervisningen på ett sätt som gör ämnet begripligt (Shulman, 1986). Gudmundsdottir (1991) har studerat "excellent teachers" och menar att det sätt som läraren orienterar sig mot ämnet påverkar hur ämnet hanteras pedagogiskt. När ämnet ska göras tillgängligt för eleverna krävs att innehållet omorganiseras. Lärarens uppfattning av innehållet är avgörande för hur detta sker.

Lee Shing, Saat och Heng Loke (2015) har gjort en forskningsöversikt över hur PCK har använts, och beskriver att begreppet PCK har specificerats inom olika ämnesdidaktiska områden. Det har bland annat använts i stor utsträckning inom forskning i ämnesdidaktik inom de naturorienterande ämnena (se till exempel Henze, van Driel \& Verloop, 2008). Inom modersmålsdidaktiken är det mer sparsamt förekommande, men det finns några exempel såsom Gudmundsdottir (1991) och Winzell (2016). PCK kan förstås på flera olika nivåer, vilka har en hierarkisk relation till varandra (Lee Shing, Saat, Heng Loke, 2015). I svenskämnet kan PCK beskrivas som en svenskdidaktisk kunskap på en övergripande nivå, men sedan finns allt mer specifik kunskap inom till exempel skrivdidaktik och mer exakt inom berättelseskrivande. Det är på den mest specifika nivån som lärandeobjekten återfinns.

PCK används ofta för att beskriva lärares kunskap och kunskapsutveckling (Lee Shing et al., 2015), och då blir begreppet kopplat till den individuella läraren. Shulman (1986) lyfter dock fram att en del i kunskapsbasen för PCK är forskning om missuppfattningar och om hur undervisning kan möjliggöra att eleverna kommer förbi dessa och förstår det aktuella innehållet på ett nytt sätt. PCK behöver alltså inte bara kopplas till lärare som individer, utan kan ses på en mer kollektiv nivå som ett forskningsfält vilket genererar kunskap som kan delas inom professionen. Det är bland annat inom detta forskningsfält som denna avhandling hör hemma. Således kan ett undersökande av ett lärandeobjekt ses som ett bidrag inom PCK (Vikström et al., 2017). Denna ämnesdidaktiska kunskap utvecklas i en process där lärarerfarenheten och teorianvändandet har betydelse.

\section{Lärarerfarenhetens betydelse i forskningspro- cessen}

I en Learning study, och i andra typer av undervisningsutvecklande forskningsmetoder, har läraren och lärarerfarenheten en viktig roll. Det innebär ett perspektiv där läraren ses som medforskare, snarare än som en som blir beforskad. Detta innebär, enligt Carlgren (2017), en förändrad syn på lärares kunskap, eftersom lärare i traditionell pedagogisk forskning företrädesvis har setts som forskningsobjekt 
och inte som medforskare med värdefull kunskap som är relevant i själva forskningsprocessen. Nedan beskrivs hur erfarenhetsbaserad kunskap byggs upp, vilket följs av olika infallsvinklar på möjligheter och utmaningar i en forskningspraktik med forskande lärare.

\section{Lärares erfarenhetsbaserade kunskap}

Lärares specifika kunskap består bland annat av ämnesdidaktisk kunskap (PCK), men även av kunskap om kontexten och eleverna (Shulman, 1987). Denna typ av yrkesspecifik kunskap byggs upp genom en kombination av en formell utbildning och förtrogenhetsbaserad kunskap (Janik, 1996). För lärare innebär det att kunskapen utvecklas i det dagliga arbetet med eleverna. Genom att möta och hantera en mängd olika situationer byggs en kunskapsbas upp som till viss del är öppen, men som även delvis består av tyst kunskap (Bulterman- Bos, 2008).

Begreppet tyst kunskap (eller tacit knowledge på engelska) myntades av Polanyi (1962a). Han menade att en kompetent utförare kan vara skicklig utan att för den skull kunna beskriva sitt handlande och sitt tänkande fullt ut. Polanyi beskriver att "we can know more than we can tell" (1962a, s. 2). Den tysta kunskapen blir således synlig i personens sätt att hantera och bedöma situationer (Polanyi, 1962b). En skicklig utövare baserar sitt handlande och sina bedömningar på känslor och intuition likväl som på uttalade normer, regler och kunskaper. Polanyi (1962a) hävdar vidare att när kunskapen kommer till uttryck ryms både teoretiska och praktiska dimensioner. Dessa tankar delas även av Ryle (1963) som påtalar att det i ett kompetent utförande av något inte går att skilja på det praktiska och det teoretiska. Den mentala processen och själva handlandet, det vill säga veta att och veta hur, är enligt Ryle inte två skilda processer. Det är en och samma process och det går inte att separera ut de olika delarna. Görandet och tänkandet är sammanflätade i själva utförandet (Ryle, 1963; Schön, 1983). Detta innebär att tanken inte nödvändigtvis föregår handlandet (Ryle, 1963). Bulterman-Bos (2008), som har analyserat lärares kunskap baserat på Polanyis teorier, beskriver att lärare har tyst kunskap som hjälper dem att snabbt bedöma, ta beslut och agera i komplexa situationer. Nya situationer bedöms och hanteras därmed utifrån delvis tyst kunskap. I en undervisningssituation innebär det att lärarens agerande till stor del bygger på erfarenheter från andra liknande situationer (Bulterman- Bos, 2008). De tankar och idéer som lärare har om undervisning är endast delvis uttalade och det är i själva undervisningssituationen som bredden och djupet av kunskapen blir synlig. Den tysta kunskapen kan till viss del både verbaliseras och utvecklas genom en professionell reflektion (Pring, 2006; Schön, 1983).

Lärares erfarenhetsbaserade kunskap behöver inte ses som enbart en praktisk kunskap. I denna avhandling ryms både teoretiska och praktiska dimensioner i detta uttryck. Det centrala är att kunskapen har växt fram genom de erfarenheter som görs i det konkreta arbetet som lärare. Kunskapen bygger alltså på den variation av situationer som har hanterats i yrket (vilket baseras på bland annat Polanyi, 1962a; 1962b, och Janik, 1994). 


\section{Forskningspraktik med forskande lärare}

Det sätt som den forskande läraren beskrivs på relaterar i stor utsträckning till vilken forskningspraktik som används som utgångspunkt i diskussionen. Det finns en rörelse som argumenterar för att lärare ska vara med och driva skolforskning (till exempel Cochran-Smith \& Lytle, 1999; Rönnerman, 2011), men det finns också kritiska röster (se Labaree, 2003).

Flera forskare (Carlgren, 2012; 2017; Cochran-Smith, 2009; Elliott, 1991; Hiebert, Gallimore \& Steigler, 2002; Pring, 2006; Somekh \& Zeichner, 2009; Stenhouse, 1981) menar att lärarerfarenheten har betydelse i hela forskningsprocessen. Rönnerman (2011) framhåller att det är lärare som har djup kunskap om den egna praktiken och att de därför kan avgöra vilka områden som behöver beforskas. Därför bör de frågor som väcks i lärares dagliga undervisningspraktik vara grunden för forskningsfrågorna. Vidare menar Rönnerman att om lärares frågor driver forskningen kan det bidra till att gapet mellan teori och praktik, mellan akademi och skola, kan minska. Förespråkare för lärardriven forskning menar att lärares erfarenhet har betydelse även i den fortsatta forskningsprocessen (BultermanBos, 2008; Pring, 2006). Enligt Pring (2006) är lärares kunskap nödvändig för att tolka, förstå och analysera vad som händer i den komplexa klassrumsmiljön, eftersom det krävs en professionell bedömning för att kunna förstå en professionell aktivitet. Lärare har kunskap om de underliggande sociala regler och värderingar som genomsyrar skolan, vilket är nödvändigt för att kunna göra en rimlig tolkning och analys av vad som sker i en skolkontext (Pring, 2006). Enligt denna argumentation har lärarerfarenheten stor betydelse för alla delar i forskningsprocessen, från frågeställningar till resultat och diskussion.

Samtidigt hävdar Labaree (2003), som kan sägas representera en traditionell uppdelning mellan den akademiska forskningen och skolpraktiken, att lärare som forskar möter svårigheter. Han beskriver att lärarerfarenheten kan vara problematisk i ett forskningssammanhang, eftersom det finns väsentliga skillnader i kulturen mellan forskningspraktiken och skolpraktiken. Därför behöver lärare som börjar forska växla förhållningssätt. Labaree beskriver denna övergång i form av fyra dikotomier. Den första dikotomin innebär en förflyttning från det normativa till det analytiska. Lärare som börjar forska behöver växla från att fokusera på det egna moraliska ansvaret för elevernas utveckling till att mer distanserat analysera den. Lärare intresserar sig för att lösa praktiska problem och Labaree menar att forskare snarare ägnar sig åt att analysera och förklara dem. Den andra dikotomin beskriver Labaree som en övergång från det personliga till det intellektuella. I läraryrket krävs en personlig relation till eleverna. Inom forskning är dock inte relationen väsentlig, utan forskaren ska fokusera på de idéer och frågor som undersöks. Denna distansering är, enligt Labaree, nödvändig i forskningen. I den tredje dikotomin påtalar Labaree vikten av att gå från det partikulära till det universella. Denna övergång innebär att den forskande läraren går från att fokusera på specifika situationer (och alla undantag som de innebär) till att se de generella slutsatser som 
går att dra. Den sista dikotomin beskrivs som en övergång från det erfarenhetsgrundade till det teoretiska. Labaree argumenterar för att lärares erfarenhetsbaserade kunskap kan vara ett problem i forskningsprocessen, eftersom den kan hindra dem från att vidga perspektiven och se teoretiska samband och modeller.

Bulterman-Bos (2008) är kritisk till Labarees beskrivna dikotomier och menar att lärares erfarenhetsbaserade kunskap i betydligt större utsträckning bör influera hela forskningsprocessen. Hon anser att det behövs en helt annan syn på lärares deltagande i forskning, ett synsätt som liknar det som genomsyrar den kliniska forskningen inom medicinsk vetenskap. Enligt Bulterman-Bos skulle detta synsätt innebära att rollen som praktiker och forskare integreras, vilket gör att Labarees motsatta par skulle fungera som komplement snarare än som dikotomier. De resultat som genereras på detta sätt skulle, enligt Bulterman-Bos, bidra till att utveckla undervisningspraktiken. Carlgren (2012) argumenterar också för att det finns ett behov av praktiknära, klinisk forskning i skolan, eftersom den kan bidra till ämnesdidaktisk kunskap som är relevant för den undervisande läraren.

Begreppet klinisk forskning kommer från medicinsk vetenskap. I en statlig utredning (SOU 2008:7) definieras den kliniska forskningen som "den forskning som förutsätter vårdens strukturer och resurser och som har som mål att lösa ett ohälsoproblem eller att identifiera faktorer som leder till ökad hälsa" (s. 9). Definitionen lyfter fram den nära kopplingen till vårdpraktiken och dess syfte, men beskriver egentligen inte vem som utför forskningen. Senare i utredningen framgår det att forskningen ofta bedrivs i samarbete mellan allt från molekylärbiologer till läkare och sjuksköterskor, som ofta även har en forskarutbildning. Det centrala är att forskningen ska behandla frågor som är grundläggande inom vård och hälsa. I ett skolsammanhang skulle detta innebära frågor som rör undervisning och lärande och att dessa frågor kan undersökas i skolpraktiken tillsammans med professionella utövare (se Bulterman-Bos, 2008).

Att lärare är aktiva i hela forskningsprocessen behöver inte tolkas som att forskare med annan bakgrund inte behövs inom skolforskningen. Inom den kliniska forskningen inom medicinsk vetenskap ses samarbetet mellan olika kompetenser och professioner som självklart (SOU 2008:7). Rönnerman (2005) påtalar att forskare och praktiker kommer in med olika slags kunskap och att det kan berika forskningsprocessen, under förutsättning att kunskapen inte värderas olika högt. Enligt Rönnerman värderas ofta den vetenskapliga kunskapen högre än erfarenhetsbaserad kunskap, vilket riskerar att bli ett hinder i kunskapsprocessen. Arhar et al. (2013) har studerat vad som händer när verksamma lärare samarbetar med akademiska forskare i gemensamma forskningsprojekt. I studien visas att de olika rollerna kan berika varandra och att de kan påverka både process och resultat. En förutsättning är dock att de släpper sina respektive roller som praktiker och akademiker, och i stället skapar ett nytt forskningssammanhang. Arhar et al. beskriver det som ett tredje utrymme, i vilket nya roller kan skapas och där forskningsintresset är i fokus. Detta tredje utrymme är således ett annat slags forskningspraktik än den traditionella akademiska forskningen. Carlgren (2017) framhåller att i denna 
typ av forskningspraktik är inte lärarna ett objekt, utan de är subjekt i forskningsprocessen och ingår i ett forskningsteam som har ett gemensamt forskningsobjekt.

När lärare är med $i$ hela forskningsprocessen uppstår en potential att bidra med kunskap som är relevant för lärarprofessionen (Pring, 2006). Enligt Graham et al. (2016) är dock skrivforskning som baseras på lärares erfarenheter ofta person- och kontextberoende, vilket gör att resultaten inte går att generalisera. Liknande kritik framförs av Shavelson, Phillips, Towne och Feuer (2003) som menar att många studier i skolmiljö innehåller så många variabler att det blir svårt att avgöra vad som orsakat resultaten. Synen på lärardriven kvalitativ forskning påverkas alltså i hög grad av synen på kunskap och kunskapsbidrag, men även av vilken roll den forskande läraren har, hur studien har genomförts och i vilken form kunskapsbidraget presenteras. I den tidiga aktionsforskningen var kunskapsbidraget framför allt att skolpraktiken förbättrades på den skola där aktionsforskningen genomfördes (Carlgren, 2012; Pring, 2006). Carlgren (2017) påtalar att forskare som deltog i aktionsforskning ofta såg lärarna som objekt och att det var lärarnas process som beforskades och beskrevs, snarare än det resultat som framkom i lärarnas studie. När resultat från själva aktionsforskningen presenterades visades, enligt Pring (2006), vad som fungerade i de aktuella klassrummen. Det fanns däremot inte något uttalat mål om att generera kunskap som kunde vara relevant utanför det specifika sammanhanget. Det sätt som kunskapen kunde delas med andra på bestod i dessa fall framför allt av det Larsson $(2005 ; 2009)$ benämner kontextlikhet, vilket innebär att en lärare själv får relatera resultaten till sin egen praktik och se om det går att hitta några relevanta kopplingar. Om kunskapsbidraget i aktionsforskning, Learnings study och likande ansatser i stället består av teoretiska beskrivningar, kan de bli relevanta även utanför den specifika kontext där de uppstod (Carlgren, 2012; Stiles, 2009; Vikström et al. 2017).

\section{Teoriers betydelse för kunskapsbidraget}

Aktionsforskning och liknande ansatser har fått kritik för att vara teorilösa (Pring, 2006). Detta stämmer också för flera av de tidiga aktionsforskningsstudierna, men numera finns flera exempel på teorianvändning och teorigenerering i denna typ av forskningsansats. Pang och Ling (2012) beskriver att resultatet i Learning study består av ämnesdidaktisk kunskap (PCK). Kunskapsprodukten bygger på en systematisk undersökning som är guidad av variationsteorin. I denna process både testas och används teorin, och ny teoretisk kunskap genereras.

\section{Teorier på olika nivåer}

De teorier som används och genereras finns på olika nivåer. För att beskriva vilken nivå en teori finns på är begrepp som används inom grundad teori applicerbara. Glaser och Strauss (1967) beskriver att det finns en viktig distinktion mellan så kallade "grand theories" och "middle-range theories". Grand theories är teorier som är skapade av stora tänkare och filosofer, och de avser förklara övergripande 
samband och sammanhang. Ett exempel är den sociokulturella teorin. Vanligen baseras inte teorin i första hand på empiriska studier, utan det är snarare ett tankearbete som ligger bakom teoribygget. Middle-range theories, som först beskrevs av Merton, är däremot mer specifika och empiriskt grundade. Enligt Glaser och Strauss (1967) kan denna typ av teori beskrivas så här: "they fall between the 'minor working hypotheses' of everyday life and the 'all-inclusive' grand theories." (Glaser och Strauss, 1967, s. 32-33)

Glaser och Strauss (1965) menar att middle-range theories kan delas upp i formella och substantiva teorier. De substantiva teorierna är inriktade mot och empiriskt grundande i ett avgränsat, specifikt område. I pedagogiska sammanhang kan det till exempel vara ämnesdidaktiska bidrag som är fokuserade på undervisningen av ett specifikt innehåll. De formella teorierna är också empiriskt grundade, men de gör anspråk på att vara mer generella. När en formell teori byggs upp är det, enligt Glaser och Strauss (1967), lämpligt att utgångspunkten är substantiva teorier och att ett större teoribygge baseras på dem. Även om den formella teorin är mer övergripande än den substantiva gör den endast anspråk på att förklara avgränsade fenomen och sammanhang. Variationsteorin har byggts upp av en mängd empiriska studier och avser att förklara lärande i ett pedagogiskt sammanhang (Marton, 2015). Därför skulle den kunna ses som en formell teori.

\section{Teorins betydelse som analysredskap}

I någon bemärkelse används alltid teoretiska antaganden som utgångspunkt vid en analys. Dessa antaganden består ibland av införlivade uppfattningar av fenomenet som studeras, och andra gånger används en explicit teori för att förklara och förstå det som sker (Elliott, 2012). Inom aktionsforskningsfältet framhålls alltmer betydelsen av att använda teoretiska modeller och teorier vid datanalysen (Pring, 2006).

Gudmundsdottir (1991) menar att teorier är de linser genom vilka forskaren betraktar det som studeras. Teorivalet påverkar därför vad forskaren ser och vad som fokuseras. Enligt Gudmundsdottir har "middle-range"-teorier potential att fungera som redskap när forskaren ska analysera en verksamhet utifrån en specifik frågeställning. Eftersom de är mer specifika än de övergripande teorierna kan de ge förklaringsmodeller som blir användbara inom just de områden som teorin gör anspråk på att förklara. Det är nödvändigt att teorin erbjuder verktyg för att titta på det aktuella fenomenet, eftersom olika teorier "tillåter" att vi ser olika saker (Gudmundsdottir, 1991; Marton, 2015). Till exempel skulle samma undervisningssekvens kunna beskrivas på olika sätt beroende av om vi använder variationsteorin eller en genusteori. Teorier ger således både möjligheter och begränsningar. Den här avhandlingen inriktar sig mot skolan och mot frågor som handlar om undervisning och lärande av ett specifikt innehåll. Därför behövs en teori som möjliggör att just detta studeras, och en sådan teori är variationsteorin. Den innehåller begrepp och tankemodeller som gör att det går att beskriva och analysera undervisning på detaljnivå (Runesson, 2017). 


\section{Genererande av ny teoretisk kunskap}

Om resultatet från forskningen utmynnar i någon form av teoretisk kunskap ökar möjligheten att studiens resultat blir intressanta även utanför det klassrum där studien genomfördes (Pring, 2006). Generaliserbarheten behöver inte bygga på att det är många fall som undersöks. Genom att studera rika, specifika och kontextuella fall går det att både testa och utveckla teoretiska antaganden (Stiles, 2009). Stiles (2009) benämner det som en abduktiv process, och den innebär en ständig växling mellan observation och teoretiska resultat. Den framväxande teorin om det fenomen som undersöks förändras och preciseras, för att passa till observationen. Teorin utvecklas fortlöpande, och resultatet blir teoretiska beskrivningar av fenomenet som undersöks. Dessa teoretiska beskrivningar visar dock inga mekaniska samband (dvs. att X leder till Y). Det skulle inte vara möjligt i pedagogiska sammanhang, eftersom personliga och sociala faktorer har så stor betydelse. I stället kan möjliga samband visas. Carlgren (2017) beskriver att det handlar om att "skapa situationer som möjliggör lärande, samt arbeta för att dessa möjligheter förverkligas" (s. 186). Det innebär att forskning kan ha visat att sambanden är möjliga, men att det krävs vissa sammanhang och förutsättningar för att sambandet ska upprättas.

I Learning study kan ovanstående typ av teoriutveckling inträda. Metoden är en systematisk ingående fallstudie som kan leda till djup kunskap om dynamiken och komplexiteten i ett kunnande och om undervisning (Carlgren, 2017). Enligt Vikström et al. (2017) är syftet med forskningsprocessen i Learning study tydligt; kunskapsbidraget handlar om att beskriva kritiska aspekter och variationsmönster. Marton och Runesson (2015) argumenterar för att de kritiska aspekter som framkommer i en Learning study ska ses som ett teoretiskt forskningsbidrag. De kritiska aspekterna är en beskrivning av vad som konstituerar lärandeobjektet, vilket har ämnesdidaktisk relevans även utanför den specifika kontext där studien genomfördes. Eftersom de kritiska aspekterna är grundade i data och avser beskriva ett avgränsat fenomen skulle de kunna ses som ett slags substantiv teori (baserat på Glasers \& Strass, 1967, beskrivning) om vad som behöver göras urskiljningsbart i undervisningen för att eleverna ska få möjlighet att utveckla den avsedda förmågan. Ett viktigt kvalitetskriterium för den substantiva teorin är dess användbarhet i liknande situationer (Glaser och Strauss, 1967). Vikström et al. (2017) beskriver att även om de kritiska aspekterna inte går att appliceras direkt kan de användas som forskningsbaserade hypoteser - hypoteser som kan testas, definieras ytterligare, preciseras och utvecklas vidare, i likhet med de "möjliga samband" som omtalas av Carlgren (2017). 


\section{METOD OCH GENOMFÖRANDE}

Avhandlingens frågeställningar handlar om hur kunnandet att skriva berättelser kan göras undervisningsbart, vilket belyses dels ur ett svenskdidaktiskt perspektiv, dels ur ett metodologiskt perspektiv. Frågeställningarna har besvarats genom data som samlades in i en Learning study bestående av en kartläggning och fem cykler. Datamaterialet har analyserats i flera omgångar, och resultaten redovisas i föreliggande avhandling. Nedan beskrivs inledningsvis deltagarna i studien och på vilka grundvalar urvalet skedde. Därefter belyses de etiska överväganden som har gjorts. Detta följs av en beskrivning av den Learning study som är underlag för avhandlingen, och efter det redovisas det empiriska underlaget. Avslutningsvis beskrivs de olika analysmetoder som har använts i avhandlingen som helhet. Där diskuteras också för- och nackdelar med valet av analys och metod.

\section{Urval}

I denna Learning study deltog fyra lärare i en forskningsgrupp tillsammans med mig ${ }^{6}$ samt 108 elever från skola A och 25 elever från skola B. På grund av frånvaro deltog inte alla elever i alla delar av processen.

Urvalet kan ses både som ett målstyrt urval och som ett bekvämlighetsurval (se Bryman, 2011). Lärare som undervisade i årskurs 2-5 på skola A blev tillfrågade eftersom lärandeobjektet passade den åldersgruppen. De lärare som var intresserade av att delta var de som kom att ingå i forskningsgruppen, vilket gör att det kan ses som ett bekvämlighetsurval. En lärare som undervisade i svenska som andraspråk blev särskilt tillfrågad, eftersom jag gärna ville att den kompetensen skulle finnas i gruppen. På det sättet var urvalet målstyrt. Baserat på detta kom forskningsgruppen att bestå av, utöver mig själv, tre klasslärare som undervisade i årskurs 3 eller 4 och en lärare i svenska som andraspråk. Det var en stor spridning avseende hur länge de deltagande lärarna hade varit verksamma i yrket. En lärare hade 40 års erfarenhet i yrket och en var nyutexaminerad. De andra två hade arbetat som lärare i 12 år respektive 6 år. Jag hade arbetat i 15 år som lärare när studien genomfördes.

Fem klasser, två i årskurs 3 och tre i årskurs 4, deltog på olika sätt i studien på skola A. De deltagande eleverna på skola $\mathrm{A}$ gick i de klasser där de deltagande lärarna undervisade och urvalet av dem är således kopplat till detta. Den femte Learning study-cykeln genomfördes på skola B. Där blev en lärare som undervisade i årskurs 4 tillfrågad om jag fick "låna" hennes klass. När läraren hade klargjort att det gick bra, tillfrågades elever och vårdnadshavare.

\footnotetext{
${ }^{6}$ Eftersom det i föreliggande avhandling är av vikt att visa vilken roll jag som forskare hade i processen, används förstapersonsbeskrivningar i flera delar av metodkapitlet.
} 
Efter genomförandet av denna Learning study analyserades delar av data på nytt. Till Thorsten (accepterad) analyserades totalt 80 elevtexter. De texter som analyserades var skrivna innan interventionen genomfördes (det vill säga från kartläggning eller från förbedömning) för att en riktad intervention inte skulle vara en faktor att beakta vid analysen. Totalt 27 elevtexter från kartläggningen och 53 elevtexter från förbedömningen analyserades, och av dessa var 40 texter från årskurs 3 och 40 texter från årskurs 4 . Det material som användes som underlag i Thorsten (2015) och Thorsten (2017) samlades in i samband med den övergripande studien.

Både skola A och B ligger i en större svensk stad, i områden med en socioekonomisk och kulturell spridning i elevgruppen.

\section{Etiska överväganden}

Vetenskapsrådets (2011) forskningsetiska principer följdes när studien genomfördes. Alla föräldrar och elever fick inför skrivuppgiften i kartläggningen skriftlig information om studien och kontaktuppgifter till mig. De sex elever som intervjuades gav alla muntligt samtycke. Även deras föräldrar kontaktades via telefon och gav sitt muntliga samtycke till att deras barn deltog i studien.

De lärare som deltog i cykel 1-4 i denna Learning study medverkade frivilligt och informerades om att de när som helst hade rätt att avbryta sitt deltagande. En lärare (utöver de som finns beskrivna under urval) klev av projektet efter ett par veckor på grund av för hög arbetsbelastning. Föräldrar och alla elever som deltog i cykel 1-5 fick fylla i en skriftlig samtyckesblankett, i vilken de kunde markera om de samtyckte till deltagande i studien eller inte. Där informerades de också om att lektionerna skulle filmas. I ett fåtal fall ville inte föräldrarna att deras barn skulle filmas. Då deltog eleverna i lektionen men satt så att de inte kom med på filmen.

Konfidentialitetskravet har mötts genom att elevers namn, skola och kommun inte nämns i någon av texterna som ingår i avhandlingen. Däremot är det möjligt att de lärare som deltog i studien skulle kunna identifiera både sig själva, de andra deltagande lärarna och sina elever. Avidentifieringen minskar dock risken för detta. All data som samlats in under studien har endast använts i forskningssyfte och datamaterialet förvaras inlåst.

Forskningsetiskt har jag strävat efter att vara transparent $\mathrm{i}$ beskrivningen av alla delar av processen. Jag har flera gånger jämfört mina kategorier med rådata, för att de ska vara så tillförlitliga som möjligt.

\section{Genomförande av Learning study}

Det kunnande som undersöktes i denna Learning study, det vill säga studiens lärandeobjekt, handlade om skrivandet av berättelser. Det preciserades under studiens gång och beskrevs slutligen som att kunna skriva en berättelse med ett välutvecklat, väl sammanhållet och spännande händelseförlopp. Studien genomfördes 
efter införandet av Lgr 11 (Skolverket, 2011) och lärandeobjektet var således kopplat till syfte och centralt innehåll i läroplanen. Först genomfördes en kartläggning och därefter fem cykler baserat på Learning study-modellen (se kapitel 4). Cykel 1-3 genomfördes under höstterminen några (månader efter kartläggningen) och cykel 4 genomfördes i maj nästföljande år. När fyra cykler var genomförda avslutade forskningsgruppen sitt arbete. Ytterligare en cykel genomfördes fristående från forskningsgruppen, sex månader senare.

\section{Kartläggning}

Inför studien genomförde jag en kartläggning i syfte att öka kunskapen om hur elever skriver berättelser. I kartläggningen deltog 27 elever i årskurs 4. Eleverna fick skriva en berättelse till en bild (bilaga 1) som föreställer två personer som ror en båt. Det finns en potentiell fara i bilden eftersom vattnet ser strömt ut. Skrivtillfället inleddes med en kort diskussion om vad bilden föreställer. Sedan uppmanades eleverna att skriva en berättelse. De fick skriva så länge de ville. Nästa steg i kartläggningen bestod av intervjuer. Sex av eleverna, som hade skrivit berättelser på olika nivåer, intervjuades om sina egna berättelser. Eleverna intervjuades enskilt utifrån en fenomenografisk ansats (se kapitel 3). Kartläggningens resultat bidrog med kunskap och tankar om vilka aspekter som skulle kunna vara kritiska i denna åldersgrupp för att utveckla det aktuella kunnandet.

\section{Cykel 1-4}

Tillsammans med forskargruppen genomfördes fyra cykler. Hela gruppen deltog under mötena i diskussioner och analyser. Jag hade rollen som forskningsledare och förberedde och efterarbetade de möten vi hade. Under mötena skrev jag mötesprotokoll. Före, under och efter mötena förde jag reflektionsanteckningar.

Det gemensamma arbetet inleddes med diskussioner om lärandeobjektet och vad kunnandet innebar. Utgångspunkten i dessa inledande diskussioner var kartläggningen, ämnesdidaktisk litteratur och vår gemensamma lärarerfarenhet. Efter de inledande diskussionerna genomförde vi en förbedömning, där vi undersökte hur de elever som skulle delta i interventionen hanterade lärandeobjektet. Eleverna fick skriva en berättelse till samma bild som användes vid kartläggningen (bilaga 1). Analysen av elevberättelserna ökade vår kunskap om möjliga kritiska aspekter. Våra tentativa kritiska aspekter låg till grund för planeringen av forskningslektionerna. I cykel 1-3 höll klassläraren för respektive klass i genomförandet av lektionerna. I cykel 4 genomförde jag undervisningen. De i forskningsteamet som inte genomförde undervisningen observerade lektionerna, antingen på plats eller via videoinspelningar. Ett par dagar efter lektionernas genomförande gjordes en efterbedömning. Även då skrev eleverna en berättelse till en bild som innehöll en potentiell, men inte självklar, fara (bilaga 2). 
Efter varje cykels forskningslektioner och efter att eleverna skrivit efterbedömningen analyserades lektionerna baserat på variationsteoretiska grundantaganden. Lektionerna reviderades sedan innan de genomfördes i en ny elevgrupp.

\section{Cykel 5}

Ett halvår efter den fjärde cykeln genomförde jag en femte cykel på skola B. Då hade forskningsgruppen upplösts. När cykel 5 genomfördes hade de kritiska aspekterna förfinats genom en ny analys, vilket lett till vissa mindre revideringar i lektionerna.

Cykeln inleddes med en förbedömning. Sedan genomfördes de reviderade lektionerna, då jag var den undervisande läraren. Ett par dagar senare gjordes efterbedömningen.

\section{Empiriskt underlag}

Det empiriska materialet kommer från genomförandet av en Learning study (kartläggning +5 cykler). I den processen samlades följande data in: elevtexter, elevintervjuer, filmade forskningslektioner, fältanteckningar från de filmade lektionerna, dokumentation från forskningsmötena samt fältanteckningar och reflektionsanteckningar från forskningsprocessen.

Elevtexterna består av berättelser som är skrivna av eleverna. De samlades in i samband med kartläggningen, och i och med för- och efterbedömningen i samtliga cykler. Sex intervjuer transkriberades ordagrant. Forskningslektionerna vid de tre första cyklerna observerades och fältanteckningar fördes. Dessutom filmades samtliga forskningslektioner. De flesta delar av dessa transkriberades ordagrant, men delar som handlade om helt andra saker (till exempel skollunchen eller någon rastaktivitet) transkriberades inte. Dokumentationen från forskningsmötena bestod av mötesprotokoll med noggranna anteckningar från mötet. Jag förde protokoll och delade dem med forskningsgruppen. Reflektionsanteckningar genomfördes både i direkt anslutning till processen och i efterhand. Reflektionsanteckningarna bestod av friare anteckningar och reflektioner, dels i relation till genomförandet av lektionerna i cykel 4 och 5, där jag själv var undervisande lärare, och dels i relation till forskningsprocessen. Tabell 1 visar en sammanställning av allt insamlat material. 
Tabell 1

Sammanställning av empiriskt underlag

\begin{tabular}{|c|c|c|c|c|c|}
\hline & Elevtexter & Intervjuer & $\begin{array}{l}\text { Filmat } \\
\text { Material }\end{array}$ & $\begin{array}{l}\text { Mötes- } \\
\text { protokoll }\end{array}$ & Anteckningar \\
\hline $\begin{array}{l}\text { Kart-lägg- } \\
\text { ning }\end{array}$ & 27 & 6 & - & - & - \\
\hline Cykel 1 & $\begin{array}{c}(11 * 2) \\
22\end{array}$ & - & $150 \mathrm{~min}$ & - & $\begin{array}{l}\text { Fält- } \\
\text { anteckningar }\end{array}$ \\
\hline Cykel 2 & $\begin{array}{c}(14 * 2) \\
28\end{array}$ & - & $270 \min$ & - & $\begin{array}{l}\text { Fält- } \\
\text { anteckningar }\end{array}$ \\
\hline Cykel 3 & $\begin{array}{c}(24 * 2) \\
48\end{array}$ & - & $230 \mathrm{~min}$ & - & $\begin{array}{l}\text { Fält- } \\
\text { anteckningar }\end{array}$ \\
\hline Cykel 4 & $\begin{array}{c}(14 * 2) \\
28\end{array}$ & - & $250 \min$ & - & $\begin{array}{l}\text { Reflektions- } \\
\text { anteckningar }\end{array}$ \\
\hline Cykel 5 & $\begin{array}{c}(22 * 2) \\
44\end{array}$ & - & $240 \mathrm{~min}$ & - & $\begin{array}{l}\text { Reflektions- } \\
\text { anteckningar }\end{array}$ \\
\hline $\begin{array}{l}\text { Möten, cy- } \\
\text { kel 1-4 }\end{array}$ & - & - & - & $\begin{array}{c}10 \text { möten } \\
\text { à } 1-4 \text { tim- } \\
\text { mar }\end{array}$ & $\begin{array}{l}\text { Fält- } \\
\text { anteckningar }\end{array}$ \\
\hline $\begin{array}{l}\text { Under och } \\
\text { efter forsk- } \\
\text { ningspro- } \\
\text { cessen }\end{array}$ & - & - & - & - & $\begin{array}{l}\text { Reflektions- } \\
\text { anteckningar }\end{array}$ \\
\hline Totalt & 197 texter & 6 & $\begin{array}{c}1140 \\
\min \end{array}$ & 10 möten & \\
\hline
\end{tabular}

\section{Analysförfarande}

För att besvara den övergripande frågeställningen "Hur kan kunnandet att skriva berättelser göras undervisningsbart?" har flera analysmetoder använts. De två underfrågorna har olika karaktär, så teorier och analysmetoder har valts för att de är lämpliga för att besvara respektive fråga. I tabell 2 ges en överblick över de analysmetoder som har använts. 
Tabell 2

Analysmetoder i respektive studie

\begin{tabular}{lllll}
\hline Studie & $\begin{array}{l}\text { Licentiat- } \\
\text { uppsats (I) } \\
\text { Thorsten } \\
\text { (2014) }\end{array}$ & $\begin{array}{l}\text { Artikel (II) } \\
\text { Thorsten (ac- } \\
\text { cepterad) }\end{array}$ & $\begin{array}{l}\text { Artikel (III) } \\
\text { Thorsten } \\
\text { (2015) }\end{array}$ & $\begin{array}{l}\text { Artikel (IV) } \\
\text { Thorsten } \\
\text { (2017) }\end{array}$ \\
\hline Analysmetod & $\begin{array}{l}\text { Fenomeno- } \\
\text { grafisk ana- }\end{array}$ & Narratologisk & $\begin{array}{l}\text { Induktiv } \\
\text { analys }\end{array}$ & $\begin{array}{l}\text { Teoretisk } \\
\text { tematisk } \\
\text { tematisk } \\
\text { analys }\end{array}$ \\
& lys & Fenomeno- & & \\
& $\begin{array}{l}\text { Variations- } \\
\text { teoretisk } \\
\text { analys }\end{array}$ & Vrafisk analys & & \\
& Variationsteo- & & \\
& retisk analys & & \\
& & &
\end{tabular}

Den första specificerade forskningsfrågan "Vad behöver 9-10-åringar erfara för att kunna skriva berättelser med ett välutvecklat händelseförlopp?" besvaras i Thorsten (2014) och i Thorsten (accepterad), med hjälp av analyser av elevernas kunnande och hur det kan utvecklas. Fenomenografi och variationsteori användes i detta sammanhang. Fenomenografi valdes eftersom metoden gör det möjligt att undersöka på vilka kvalitativt skilda sätt kunnandet att skriva en berättelse kan komma till uttryck (jämför med Marton \& Booth, 2000). Variationsteorin lämpade sig som analysverktyg för att undersöka och beskriva hur elevernas kunnande kan utvecklas, eftersom teorin används för att beskriva kritiska aspekter och hur de kan synliggöras i undervisningen (Runesson, 2017). Både fenomenografi och variationsteori behöver även bygga på ämnesdisciplinära och ämnesdidaktiska metoder och teorier. I Thorsten (accepterad) användes därför narratologiska teorier för en första analys, vilken sedan användes som grund i det fortsatta analysarbetet. Kombinationen av ämnesdisciplinära och ämnesdidaktiska teorier med variationsteorin kan ses som både nödvändig och självklar, eftersom teorierna fyller olika funktion (Johansson \& Thorsten, 2017).

Den andra forskningsfrågan är "Hur används lärares erfarenhetsbaserade kunskap tillsammans med variationsteori när ett kunnande om berättelseskrivande undersöks och utvecklas i en Learning Study?", och den adresseras i Thorsten (2015) och Thorsten (2017). I Thorsten (2015) används en induktiv tematisk analys (utifrån Braun och Clarke, 2006) för att beskriva hur ett kunnande kan undersökas. I Thorsten (2017) kan analysen i stället ses som en teoretisk tematisk analys (utifrån Braun och Clarke, 2006). Då bidrar de givna kategorierna som underlag för att belysa och diskutera centrala områden i forskningsprocessen.

I respektive publikation redogörs för analysförloppet som helhet. Nedan ges i stället en beskrivning av de olika typer av analysmetoder som har använts i materialet. De beskrivs inte i kronologisk ordning utan baserat på att vissa analyser byggde på varandra. Därför inleds avsnittet med en beskrivning av narratologisk analys följt av fenomenografisk analys, eftersom den fenomenografiska analysen 
i artikel I bygger på den narratologiska analysen. Därefter beskrivs variationsteoretisk analys, och avslutningsvis induktiv och teoretisk tematisk analys.

\section{Narratologisk analys}

I Thorsten (accepterad) analyserades 80 elevtexter från ett narratologiskt perspektiv. Syftet var att ge en grund för den kommande fenomenografiska analysen, genom att undersöka hur de olika berättelserna var uppbyggda. Analysen var inspirerad av Propps (1928/2015) och Chatmans (1978) respektive analysmodeller. I sin analys sökte Propp efter funktioner och händelser i sagor (se kapitel 2). Det är dessa funktioner som driver berättelsen framåt. Propp beskriver innehållsliga och specifika funktioner, till exempel hjälten lämnar hemmet. I min analys har jag inte sökt efter funktioner i den bemärkelsen, utan i stället undersökt vilken funktion olika delar har, baserat på en berättelses struktur snarare än dess innehåll. Detta sätt är inspirerat av Chatmans (1978) beskrivning av narrativa block (se kapitel 2).

Inledningsvis lästes varje text igenom ett par gånger för att lära känna både de enskilda texterna och textmaterialet som helhet. I nästa steg analyserades 25 texter. Då delades varje text upp i mindre narratologiska enheter avseende vilken funktion de hade. Bredvid varje sådan enhet skrevs en kort kommentar om textens funktion. I denna första fas användes olika koder beroende på vad som passade den aktuella texten, till exempel introduktion. Efterhand som texterna gicks igenom upprepades vissa koder, eftersom samma funktion fanns i flera texter. Då sammanfördes likartade kodnamn, till exempel introduktion och lägesbeskrivning. Andra funktioner i texten som framkom var till exempel dramatisk händelse och beskrivning av aktivitet.

De koder som analysen av de första 25 texterna resulterade i, användes som underlag när resten av texterna analyserades. I den processen preciserades benämningarna och ett fåtal nya kodnamn tillkom. När alla 80 texter analyserats på detta sätt var varje text indelad i narratologiska enheter. Denna analys utmynnade inte i ett resultat som redovisades, utan den visade vilka delar av berättandet som eleverna fokuserade på. På så sätt utgjorde den ett underlag för den fortsatta fenomenografiska analysen

Den narratologiska analysen har fördelen att den riktar fokus mot berättelsens struktur och ger redskap för att få syn på olika komponenter som påverkar det färdiga alstret. En kritik mot metoden skulle kunna vara att den kan upplevas som instrumentell och att vissa aspekter av berättelsen inte beaktas i analysen.

\section{Fenomenografisk analys}

Det kunnande som undersöks i denna avhandling är berättelseskrivande. För att beskriva kunnandet användes fenomenografi, dels i Thorsten (2014) där sex intervjuer analyserades, dels i Thorsten (accepterad) som en påbyggnad på den narratologiska analysen som beskrevs ovan. I en fenomenografisk analys är strävan att se berättelseskrivandet ur elevernas perspektiv. Målet är, enligt Marton och Booth 
(2000), att beskriva kvalitativt skilda sätt att uppfatta ett fenomen. Detta bygger på ett antagande om att det på en kollektiv nivå finns ett begränsat antal sätt att erfara ett och samma fenomen (Marton, 1981). Intresset ligger därför inte i att beskriva uppfattningar på en individuell nivå eftersom en och samma individ kan ge uttryck för flera uppfattningar (se beskrivning i kapitel 3).

Fenomenografiska analyser baseras vanligen på intervjuer, och det gäller även i Thorsten (2014). I Thorsten (accepterad) ville jag pröva att också fenomenografiskt analysera elevernas skrivalster. Inspiration kom bland annat från Nyberg (2014) som har analyserat elevers dans fenomenografiskt. Där analyseras själva kunnandet och hur det kommer till uttryck. Denna typ av fenomenografisk analys bygger på ett antagande om att det sätt vi erfar något på syns i hur vi hanterar det, och att hur vi hanterar något syns i själva utförandet och även i den produkt vi skapar.

Nedan beskrivs stegen i den fenomenografiska analysen. I båda analyserna (av intervjuer och berättelser) har samma steg följts, och därför beskrivs de tillsammans. Viktigt att poängtera är dock att analyserna skedde separat från varandra och vid olika tillfällen. Processen inleds med ett sökande efter beskrivningskategorier, vilka sedan placeras i ett utfallsrum.

\section{Beskrivningskategorier}

Vid båda analyserna söktes efter vad eleverna såg berättelser och berättelseskrivande som, utifrån elevernas utsagor (i Thorsten, 2014) respektive elevernas texter (i Thorsten, accepterad). I analyserna söktes efter likheter och skillnader i elevernas sätt att tala om berättelseskrivande liksom i deras sätt att bygga upp en berättelse. Målet var att ur andra ordningens perspektiv kunna beskriva olika uppfattningar om berättelseskrivande. I båda analyserna växte beskrivningskategorier fram genom att jag inledningsvis skrev ord och möjliga tolkningar bredvid de transkriberade intervjuerna eller de renskrivna elevtexterna.

Inom varje analys (av intervjuer respektive elevtexter) jämfördes dessa möjliga tolkningar med varandra. På så sätt skapades kategorier som sinsemellan var kvalitativt skilda åt. Varje kategori representerade olika sätt att erfara ett och samma fenomen. Vid analysen av intervjuerna i licentiatuppsatsen framträdde till exempel kategorin berättelsen som att ge karaktärerna en ideal upplevelse. Denna kategori baserades på utsagor där informanten pratade om allt positivt som karaktärerna upplevde och om att karaktärerna skulle undvika faror. Denna typ av uttalanden analyserades utifrån andra ordningens perspektiv (se Marton, 1981 samt kapitel 3). Genom att analysera vad informanterna fokuserade på blev det möjligt att tolka vad eleverna såg berättelseskrivande som.

Samma strävan fanns även vid analysen av de 80 elevberättelserna i Thorsten (accepterad). Då var det dock inte utsagor om texterna som analyserades, utan själva texten. Den narratologiska analysen av elevernas texter fungerade som underlag $\mathrm{i}$ analysen. Textens uppbyggnad utgjorde således grunden för en tolkning 
av hur eleverna uppfattade berättelseskrivande. Detta baseras på ett antagande om att det vi gör (i detta fall skriver en berättelse) utgår från hur vi urskiljer och förstår vår omvärld (se Marton, 2015). Hounsell (1984) visade i sin studie att historiestudenters sätt att resonera kring och uppfatta skrivgenren även genomsyrade deras färdiga alster. I min analys av elevtexterna tolkades därför olika sätt att lägga upp texten som olika sätt att uppfatta och förstå fenomenet berättelseskrivande. Till exempel innehöll vissa texter en mängd lösryckta händelser med mycket dramatik. Tolkningen av detta blev att en uppfattning om berättelseskrivande skulle kunna vara att skapa action.

Baserat på Marton och Booth (2000) innebar nästa steg i analysen att säkerställa att kategorierna var för sig var kvalitativt skilda åt och att de beskrev något distinkt om hur lärandeobjektet (det vill säga kunnandet) erfars. Det ledde till att kategorier både delades upp och slogs samman. Enligt Marton och Booth (2000) bör det finnas så få kategorier som möjligt, samtidigt som alla uppfattningar som kommer till uttryck i materialet ska täckas in. Det finns, påtalar Marton och Booth (2000), ett begränsat antal sätt att erfara ett och samma fenomen. Detta blev tydligt i framför allt min analys av elevtexterna, då samma uppfattningar återkom oftare ju fler texter som analyserades. Det är dock omöjligt att hävda att inga andra kategorier skulle framträda i ett annat material. Detta gäller framför allt för intervjuerna, eftersom de var så få, men även för elevtexterna. De uppfattningar som framkommer påverkas av elevernas tidigare erfaranden och sammanhang (se Marton \& Booth, 2000), vilket gör att andra kategorier hade kunnat framträda i en annan kontext. Kategorierna som beskrivs är en del av det som konstituerar det aktuella kunnandet, men gör inte anspråk på att vara heltäckande. Det är också möjligt att eleverna har andra tankesätt och uppfattningar som rör berättelseskrivande, men att de blir begränsade av sin skriftliga förmåga när de själva ska skriva en berättelse, eller att vissa uppfattningar inte visar sig i just detta datamaterial. Detta till trots, menar jag att artikeln kan bidra med kunskap om möjliga uppfattningar av berättelseskrivande. De kategorier som har skapats bygger på ett möjligt samband mellan det eleverna gör och det de erfar. Carlgren (2017) menar att i kvalitativa studier är det just möjliga samband som kan visas.

\section{Utfallsrum}

Den sista fasen i analysarbetet bestod av att skapa ett utfallsrum. Marton och Booth (2000) beskriver att kategorierna ofta kan placeras hierarkiskt i relation till varandra. Det innebär att någon kategori inbegriper urskiljandet av flera nödvändiga aspekter och således är mer kvalitativt utvecklad och mer komplex än de andra kategorierna. I analysen av intervjuerna framträdde berättelsen som att ge en läsupplevelse som hierarkiskt överordnad de andra båda kategorierna i samma analys. Vid analysen av elevernas berättelser var en kategori, författa en berättelse, mer komplex än de andra kategorierna och blev därför hierarkiskt överordnad. I den analysen är de andra fyra kategorierna horisontella, vilket innebär att ingen av 
de är mer komplex än de andra. Det är snarare så att i dessa kategorier fokuseras på olika aspekter.

\section{Variationsteoretisk analys}

Variationsteorin användes i den avslutande analysen i Thorsten (accepterad) och i analysen av forskningslektionerna $i$ Thorsten (2014). Teorin ger redskap för att beskriva vad som behöver synliggöras i undervisningen (kritiska aspekter) och hur dessa kan göras tillgängliga för eleverna (variationsmönster), se kapitel 4.

\section{Variationsteoretisk analys av berättelser}

Det sista steget i analysen av elevtexterna i Thorsten (accepterad) innebar en beskrivning av kritiska aspekter. Till grund för denna analys låg den fenomenografiskt inspirerade analysen som beskrevs tidigare. Enligt Pang och Ki (2016) kan en fenomenografisk analys utgöra underlag för att hitta kritiska aspekter. Aspekterna kan identifieras genom att söka efter skillnader mellan olika sätt att uppfatta ett lärandeobjekt.

Analysen innebar (baserat på Pang och Ki, 2016) ett sökande efter vilka aspekter av berättelseskrivande som framträdde $\mathrm{i}$ en jämförelse mellan de olika kategorierna. Skillnader mellan kategorierna skrevs först som koder. I nästa steg fördes olika koder samman och formulerades som kritiska aspekter, till exempel att urskilja den narrativa strukturen. Aspekterna beskrev en dimension av variation som eleverna behövde urskilja. I varje dimension av variation hittades olika värden, till exempel ett grundläggande händelseförlopp och ett utökat händelseförlopp. Dessa värden beskriver kvalitativa skillnader i hur eleverna hanterade den aktuella aspekten. De sorterades och jämfördes baserat på hur kvalitativt utvecklade de var. Dessa värden visade i vilken grad och på vilket sätt den kritiska aspekten var urskild.

\section{Variationsteoretisk analys av forskningslektioner}

En variationsteoretisk analys av forskningslektioner fokuserar vanligen på undervisningens upplägg i relation till elevernas lärande (Runesson, 2017). Fokus ligger således dels på hur eleverna uppfattar lärandeobjektet och vilka aspekter som kan vara kritiska, och dels på vilka variationsmönster som användes för att synliggöra de kritiska aspekterna. Analysen av forskningslektionerna skedde i två omgångar, både $\mathrm{i}$ direkt anslutning till genomförandet och i efterhand. Vid båda dessa analyser gjordes en variationsteoretisk analys, men re-analysen var djupare och mer genomarbetad. Detta berodde bland annat på att helhetsbilden av alla cykler ledde till nya perspektiv och ny kunskap.

Kunskapen om de kritiska aspekterna ökade genom en analys av elevernas hantering av uppgifter som de fick under lektionerna samt deras dialog med varandra och med läraren. Till exempel framkom i den första cykeln att eleverna 
inte förstod innebörden av begreppet "händelseförlopp". Den analysen ledde till att lärandeobjektet specificerades och nya kritiska aspekter framkom.

Innehållets behandling och variationsmönster analyserades också. Runesson (2017) och Lo (2012) påtalar att elevernas lärandemöjligheter påverkas av vilka exempel som ges, i vilken ordning olika saker tas upp och vad som behandlas samtidigt. Därför studerades vad som varierade och vad som var invariant, och vilka kontraster och generaliseringar som skapades i och med det. Baserat på variationsteoretiska antaganden kunde slutsatser då dras om vilket lärande som blev möjligt. Exempelvis framkom att kontrasten mellan ett välutvecklat och ett torftigt händelseförlopp gjorde att eleverna förstod vikten av ett händelseförlopp. För att de själva skulle kunna använda den kunskapen, var det dock nödvändigt att också kontrastera skillnaderna mer detaljerat.

För att undersöka hur undervisningen påverkade elevernas berättelseskrivande analyserades forskningslektionerna i relation till elevernas skrivande före och efter interventionen. Det innebar att elevernas texter från för- respektive efterbedömningen analyserades på individnivå. Textanalysen baserades på de kritiska aspekterna i kombination med bedömningsunderlaget för skrivuppgiften i det nationella provet för årskurs 6 (Skolverket, 2013). Det innebar en analys av antalet problem och lösningar i elevernas berättelser. Dessutom bedömdes de utifrån tre kvalitativa kriterier: begriplighet, sammanhang och intrig. Analysen av för- och efterbedömningen sattes i relation till undervisningen för att se om de kritiska aspekterna och deras behandling i undervisningen påverkade elevernas lärande.

\section{Tematisk analys}

Genom två olika typer av tematisk analys adresserades forskningsprocessens betydelse för att undersöka och utveckla ett kunnande. Braun och Clarke (2006) beskriver att data kan analyseras tematiskt antingen induktivt, med teman som härleds ur data, eller teoretiskt, baserat på vissa teoretiska antaganden eller givna teman (Braun och Clarke, 2006). Genom att belysa liknande forskningsfrågor dels induktivt (Thorsten, 2015), dels genom förutbestämda teman (Thorsten, 2017), var min intention att artiklarna sammantaget kan ge en rikare bild av både lärarerfarenhetens och variationsteorins betydelse i processen.

Vid datainsamlingen till de båda artiklarna var jag själv en deltagare i de analyserade processerna, och egna reflektionsanteckningar har använts som empiri. De kan beskrivas som ett slags personliga fältanteckningar eller som memos, eftersom de handlar om processen och de insikter och reflektioner som framkom under den. Stake (2010) menar att det inifrånperspektiv som den deltagande observatörsrollen ger, möjliggör en beskrivning av aspekter som kan vara dolda för en forskare som har ett utifrånperspektiv. Den deltagande forskaren behöver dock vara medveten om risken för att andra delar blir dolda. Därför har jag i båda dessa tematiska analyser växlat mellan närhet och distans, och även kritiskt diskuterat min analys med andra forskare, vilket lyfts fram som nödvändigt av Pring (2006). 
Jag har också strävat efter att vara transparent i hur forskningsprocessen sett ut, för att öka studiens trovärdighet.

\section{Induktiv tematisk analys}

I Thorsten (2015) gjordes en induktiv tematisk analys baserat på Braun och Clarke (2006). Detta innebar att teman växte fram ur det empiriska materialet. Data bestod av mötesprotokoll, fältanteckningar, videoinspelade lektioner och reflektionsanteckningar från forskningsprocessen. Analysen ska inte ses som en helt öppen analys, utan via forskningsfrågorna riktas blicken mot specifika företeelser, vilket påverkar vad som djupstuderas. Braun och Clarke (2006) beskriver en rad steg som forskaren går igenom: (1) lära känna materialet, (2) ställa frågor till materialet och skapa empirinära koder, (3) sortera koderna och söka efter teman, (4) jämföra koder och skapa teman, (5) precisera temana samt (6) rapportera temana.

I det första steget lärde jag känna materialet och gick igenom all data. I det andra steget ställde jag frågor till materialet: Vad diskuteras på mötena? Hur diskuteras det? Hur tolkas och används variationsteorin av lärarna? Hur används lärarnas erfarenhetsbaserade kunskap i processen? Hur kommer variationsteorin och lärarnas erfarenhetsbaserade kunskap till uttryck på de genomförda lektionerna? Finns det några skillnader mellan cyklerna avseende hur lärarna undervisar och resonerar? Jag skrev kortare beskrivningar och reflektioner om vad som var intressant i relation till frågorna. Jag noterade bland annat vad lärarna pratade om, till exempel "ger förslag på rolig aktivitet" och skapade på så sätt empirinära koder.

I steg 3 och 4 sorterades och grupperades koderna. De jämfördes med varandra och grupperades i möjliga teman. Denna process pågick fram och tillbaka. Exempelvis placerades lärarnas hantering av undervisningsinnehållet in under ett tema som till slut kom att kallas fokus på lärandeobjektet. I det temat beskrevs hur lärarna gick från att fokusera nästan enbart på hur-frågan till att alltmer beakta vad de ville att eleverna skulle lära sig.

När ett första förslag till teman var lagt, gick jag återigen igenom all empiri fokuserat på hur lärares praxiserfarenhet var synlig och hur den kunde påverkas av och samverka med variationsteorin. Detta ledde till att temana delvis förändrades och att de fick en tydligare innebörd. Det femte steget innebar således att temana både preciserades och befästes. Braun och Clarke (2006) skriver att varje tema ska ha ett eget fokus även om det finns teman som delvis överlappar varandra. I den aktuella analysen finns ett visst överlapp, men temana har olika infallsvinklar, vilket gör att de är kvalitativt skilda åt. I det sjätte och sista steget rapporterades temana och stöttades upp med lämpliga excerpt.

\section{Teoretisk tematisk analys}

Även i Thorsten (2017) gjordes en tematisk analys, men då utgick jag i stället från förutbestämda teman. Angreppssättet kan liknas vid en teoretisk tematisk analys (se Braun \& Clarke, 2006). Huvudintresset låg i att beskriva vad det innebar att 
vara både lärare och forskare, utifrån de dikotomier som Labaree (2003) har beskrivit som fyra motstående begreppspar (se kapitel 4). I studien avsåg jag att testa Bolterman-Bos (2008) hypotes om att dikotomierna kunde verka tillsammans i stället för att vara motsatspar. Empirin från Learning study blev ett underlag för att $\mathrm{i}$ en fallstudie se om, och i så fall hur, de beskrivna kunskapskulturerna samverkade. I analysen söktes därför inte efter teman i empirin, utan de fyra begreppsparen var utgångpunkt $i$ analysen.

Analysprocessen inleddes med att jag lärde känna materialet och fick en överblick över all ingående data. Då fokuserade jag inte på Labarees dikotomier. Jag läste igenom all data och tittade på de filmade forskningslektionerna. Dessutom formulerade jag mina egna erfarenheter på nytt, för enligt Bulterman-Bos (2008) kan analysen fördjupas om den personliga erfarenheten beaktas och används. I nästa steg i analysen utgick jag från Labarees (2003) beskrivna dikotomier, vilka nu sågs som åtta teman som var parvist sammankopplade. I allt mitt datamaterial sökte jag efter uttryck för dessa teman. Jag förde anteckningar om vilka olika sekvenser som kunde placeras in i de förutbestämda temana. Till exempel placerades tecken på när och hur den erfarenhetsbaserade kunskapen användes in under ett tema. På detta sätt framträdde en allt klarare bild över vilken funktion de olika kunskapskulturerna hade haft i forskningsprocessen. I analysen pågick en ständig växling mellan innebörden i Labarees begreppspar och det egna datamaterialet, i vilket jag inkluderar egna erfarenheter från forskningsprocessen. Gränsdragningen mellan vissa teman var inte alltid självklar, till exempel skillnaden mellan det teoretiska och det intellektuella. Där krävdes flera läsningar av Labarees beskrivning, vilket mynnade ut $\mathrm{i}$ att vissa exempel placerades om. I viss mån kvarstod en viss överlappning mellan temana. I den avslutande fasen studerades återigen beskrivningarna och exemplen på de olika begreppsparen, i syfte att göra dem mer stringenta. 


\section{AVHANDLINGENS STUDIER}

Avhandlingen består av en licentiatuppsats och tre artiklar. Samtliga studier baseras på data från samma Learning study-process.

\section{Publikation I: Licentiatuppsats}

Perspektiv och problemlösning i berättelseskrivande. Vad elever behöver lära sig och hur det kan synliggöras i undervisningen.

Thorsten (2014).

Syftet med licentiatuppsatsen är att öka kunskapen om vad elever i årskurs 3 och 4 behöver erfara och urskilja för att skriva berättelser med ett välutvecklat, spännande och väl sammanhållet händelseförlopp samt om hur undervisningen kan möjliggöra detta. Learning study användes som metod. Det är en interventionsstudie där en forskningsgrupp planerar, genomför och analyserar forskningslektioner i ett cykliskt förlopp, med fokus på elevers lärande (Lo, 2012; Marton, 2015). I studien genomfördes totalt fem cykler. Variationsteorin (baserat på bland annat Marton, 2015) användes som teoretiskt ramverk.

Data bestod av elevers skrivalster från dels en kartläggning, dels en skrivuppgift före och efter interventionen, sex elevintervjuer och inspelade forskningslektioner. I hela processen låg fokus på att undersöka och testa vilka aspekter som är kritiska för eleverna att urskilja och på hur variationsmönster kan användas i undervisningen för att möjliggöra lärande. En fenomenografisk analys av intervjuerna bidrog med kunskap om skilda sätt att erfara berättelseskrivande. Elevtexterna analyserades på individnivå för att analysera upplägget $\mathrm{i}$ berättelserna och se om, och på vilket sätt, eleverna eventuellt hade utvecklat sitt skrivande efter forskningslektionerna. Analysen av elevalstren relaterades till en analys av forskningslektionerna för att se om undervisningen möjliggjorde utveckling av det avsedda kunnandet. Analysen av forskningslektionerna fokuserade på hur eleverna urskilde lärandeobjektet och på innehållets behandling i form av variationsmönster. Huvudresultatet i licentiatuppsatsen är en beskrivning av kritiska aspekter och av hur variationsmönstren påverkade möjligheten till lärande.

I den fenomenografiska analysen framkom tre kvalitativt skilda sätt att uppfatta berättelseskrivande (a) berättelsen som fantasi, (b) berättelsen som att ge karaktärerna en ideal upplevelse, och (c) berättelsen som att ge en läsupplevelse. Den första kategorin karakteriseras av att berättelsen ses som en pågående fantasi och inte som en färdig produkt som skulle kunna presenteras för en läsare. I den andra ligger fokus på att skapa en berättelse där karaktären får det så bra som möjligt. 
Den sista kategorin är den kvalitativt mest utvecklade och mest komplexa. Då uppfattas berättelsen som ett medvetet sätt att skapa ett intresse och en upplevelse hos en läsare.

Baserat på den fenomenografiska analysen och analyser av elevalster och forskningslektioner framkom åtta kritiska aspekter. Dessa aspekter delades in i två områden: aspekter som relaterar till läsarperspektivet och aspekter som relaterar till en berättelses struktur. Fyra aspekter finns inom varje område.

Följande aspekter relaterar till läsarperspektivet:

- urskilja att en berättelse är en fantasiprodukt som ska kunna förstås av en mottagare

- urskilja att syftet med berättelser är att underhålla

- se skillnaden mellan att ge karaktärerna en ideal upplevelse och att ge läsaren en upplevelse

- urskilja att ovanliga händelser ofta skapar mer spänning än väntade och vanliga händelser.

Följande aspekter relaterar till en berättelses struktur:

- urskilja att ett huvudproblem och dess lösning kan bestå av flera delproblem och lösningar

- se att händelserna mellan huvudproblem och huvudlösning kan variera

- erfara berättelseskrivande som problemlösning

- urskilja att problemen och lösningarna ska vävas samman till en trovärdig helhet utifrån berättelsens logik.

De kritiska aspekterna synliggjordes i undervisningen med hjälp av kontraster som bäddades in aktiviteter som var lämpliga för elevgruppen. Eleverna fick analysera en textkontrast, samtala om en filmad sagas uppläggning och planera och spela upp dramatiseringar i grupp. Vid analysen av elevernas skrivalster framkom att eleverna utvecklade sin förmåga att skriva berättelser efter forskningslektionerna i cykel 2-5. Särskilt tydligt var detta i de två sista cyklerna. Analysen visar att $\mathrm{i}$ dessa cykler användes variationsmönster som ett kraftfullt redskap för att synliggöra de kritiska aspekterna i undervisningen.

De kritiska aspekter som framkom i uppsatsen är en del av vad som konstituerar kunnandet att skriva berättelser. De kan därför utgöra en grund för lärare som ska undervisa inom detta område. 


\section{Publikation II: Artikel}

How to compose a narrative - Students' approaches and pedagogical implications.

Thorsten (accepterad).

Syftet med artikeln är att öka kunskapen om hur elever uppfattar och tar sig an berättelseskrivande och om vilka aspekter av berättelseskrivande som elever urskiljer. Analysen i artikeln baseras dels på narratologiska teorier (främst Chatman, 1978 och Propp, 1928/2015), dels på fenomenografi och variationsteorin (främst baserat på Marton, 2015). Totalt 80 elevberättelser skrivna av elever i årskurs 3 och 4 analyserades i tre steg. I det första steget gjordes en narratologisk analys i vilken varje berättelses berättelsestruktur analyserades. Baserat på den analysen gjordes en fenomenografisk analys för att se vilka uppfattningar om berättelseskrivande som kunde ligga bakom de olika sätten att lägga upp en berättelse på. Detta utmynnade i ett utfallsrum med fem kategorier. I det sista steget jämfördes dessa kategorier med varandra, och i skillnaden mellan kategorierna framträdde kritiska aspekter och olika sätt att urskilja dessa.

Resultatet består av två delar, elevuppfattningar och kritiska aspekter. Elevuppfattningarna kan beskrivas i fem kategorier som visar olika sätt att se på berättelseskrivande. Den mest kvalitativt utvecklade kategorin är författa en berättelse. I den kategorin syns på olika sätt att skribenten riktar sig till en läsare. De andra fyra kategorierna är horisontella. I kategorin beskriva händelser fokuserar skribenten på att ge vardagliga beskrivningar av aktiviteter och utflykter. Det finns ingen tydlig intrig i dessa texter. Den kategorin som flest elevtexter hamnar i är lösa problem. I dessa texter finns det alltid någon form av problem, men det löses väldigt fort. Även kategorin skapa action innehåller problem, och då handlar det om flera dramatiska problem som är löst sammanhållna. Den sista kategorin är skapa interna skämt. Där drivs berättandet av interna skämt mellan skribenter.

I de nämnda kategorierna går det att urskilja olika aspekter av skrivande, och fem stycken visade sig vara kritiska i det aktuella elevunderlaget. En aspekt handlar om att urskilja en läsare. Detta kunde urskiljas på tre olika sätt: ingen läsare adresseras, en specifik läsare adresseras eller det finns en abstraktion av möjliga läsare. Nästa kritiska aspekt är att urskilja syftet med berättelser. Syftet urskildes som att beskriva, att vara i en fantasi eller att underhålla en läsare. En annan kritisk aspekt handlar om att urskilja den narrativa strukturen enligt följande sätt: ingen narrativ struktur, en grundläggande narrativ struktur eller en utökad narrativ struktur. En fjärde aspekt beskriver att urskilja sammanhang. Hur väl texterna skapade en sammanhängande helhet syntes på följande tre sätt: som hopp i händelseförloppet, som sammanlänkningar på den lokala nivån eller som sammanlänkningar mellan den globala och lokala nivån. Den sista aspekten handlar om att urskilja utrymme. Hur mycket utrymme olika delar får i berättelsen syntes på följande sätt: 
som ytterst få beskrivningar, som beskrivningar av slumpmässiga detaljer eller som beskrivningar med detaljer som är relevanta för intrigen.

De varierade uppfattningar som framkom i elevernas skrivalster, liksom de kritiska aspekterna, bidrar med kunskap inom svenskdidaktik. Denna kunskap kan vara relevant både för lärare när de ska planera sin undervisning och för vidare forskning inom området.

\section{Publikation III: Artikel}

How teachers' practice knowledge is used and challenged in a Learning Study using Variation Theory as a tool.

Thorsten (2015).

Syftet med artikeln är att bidra med kunskap om vad som sker i forskningsprocessen när lärares erfarenhetsbaserade kunskap möter variationsteorin. Utgångspunkten är en Learning study om berättelseskrivande.

Teoretiskt baseras artikeln på två delar. I den första delen behandlas forskning och teorier om erfarenhetsbaserad och tyst kunskap, bland annat utifrån Polanyi (1962a, 1962b) och Ryle (1963). I den andra delen beskrivs grundantaganden i variationsteorin (baserat främst på Marton, 2015 och Lo, 2012) och forskning om hur Learning study och Lesson study påverkar lärares kunskapsutveckling (baserat främst på Dudley, 2013 och Elliott, 2012).

Data består av fältanteckningar, mötesprotokoll, filmade lektioner och reflektionsanteckningar. Data analyserades i en induktiv tematisk analys (se Braun och Clarke, 2006). All data sorterades och kodades utifrån hur lärares erfarenhetsbaserade kunskap användes i processen och hur användningen av variationsteorin påverkade processen. Detta mynnade ut i fem teman. I varje tema finns i olika utsträckning beskrivningar av både lärares erfarenhetsbaserade kunskap och variationsteorins påverkan, genomgående med fokus på hur detta kommer till uttryck i ett svenskdidaktiskt sammanhang. I mötet mellan lärares erfarenhetsbaserade kunskap och variationsteorin framkom fem teman:

(1) fokus på lärandeobjektet

(2) ha ett gemensamt språk för att tala om undervisning och lärande

(3) synliggöra lärares antaganden

(4) synliggöra variationsmönster i undervisningen

(5) analysera den egna undervisningen - svårigheter och möjligheter.

Det första temat beskriver att lärargruppen själva väljer ett lärandeobjekt inom skrivundervisningen, men att de spontant fokuserar på vilka aktiviteter som ska skapas, snarare än på vad som ska läras. Variationsteorins fokus på lärandeobjektet och de kritiska aspekterna förflyttade delvis fokus, vilket gjorde att vad-frågan ge- 
nomsyrade hur-frågan. I det andra temat framgår att lärarna använder en kombination av begrepp från praktiken och begrepp från variationsteorin. Det tredje temat beskriver att lärarna delar sina idéer med varandra. Lärarna får också syn på dolda antaganden när de möter variationsteorin, vilket gör att de kan förvärva nya synsätt på undervisning och lärande av berättelseskrivande. I det fjärde temat framkommer att variationsteorin bidrar med variationsmönster men att dessa måste bäddas in i lämpliga aktiviteter för att bli kraftfulla. Lärarnas erfarenhetsbaserade kunskap och kunskap om eleverna var därför avgörande. I det sista temat beskrivs att lärarnas erfarenhetsbaserade kunskap är betydelsefull för att fokus riktades mot även små signaler från eleverna. I det inledande skedet fokuserade lärarna mycket på elevuppförande och lärarens personliga beteende. Variationsteorin förflyttade intresset även till innehållets behandling och elevers lärande.

I studien framkom hur lärares erfarenhetsbaserade kunskap både användes och utmanades i en Learning study där lärandeobjektet handlade om elevers berättelseskrivande och där variationsteorin var ett teoretiskt och pedagogiskt redskap.

\section{Publikation IV: Artikel}

Generating knowledge in a Learning Study-from the perspective of a teacher researcher.

Anja Thorsten (2017).

Syftet med artikeln är att ge ett metodologiskt bidrag för att diskutera rollen som forskande lärare i en Learning study om berättelseskrivande, med fokus på forskningsprocessen och de resultat som genereras.

Artikeln tar sin utgångspunkt i teoretiska resonemang om den forskande lärarens forskarroll. Labaree (2003) beskriver hur lärare som börjar forska behöver gå från en kultur som är normativ, personlig, erfarenhetsgrundad och partikulär till forskarmiljön som är analytisk, intellektuell, teoretisk och universell. BultermanBos (2008) argumenterar mot denna beskrivning och menar att det inte behöver var dikotomier, utan att de olika förhållningssätten kan mötas i en klinisk forskningspraktik. Baserat på Bulterman-Bos (2008) argumentation bidrar artikeln med ett inifrån-perspektiv från den forskande läraren. Labarees (2003) dikotomier fungerade som förutbestämda teman. Data från en genomförd Learning study användes som underlag för analysen tillsammans med reflektionsanteckningar som gjordes både under och efter forskningsprocessen.

I resultatet beskrivs hur Labarees (2003) begreppspar i en praktiknära forskning inte blir dikotomier, utan sammanvävs och fungerar parallellt. Det första begreppsparet är det normativa och det analytiska. Där framkommer att skolan är en normativ miljö och lärares frågor därmed alltid har en normativ aspekt. Analysen riktar in sig mot elevers lärande av en specifik förmåga, i detta fall förmågan att skriva en berättelse. Det andra begreppsparet är det erfarenhetsbaserade och det teoretiska. Teorier om skrivande och skrivutveckling samt variationsteorin var 
vägledande i hela processen. För att vara kraftfulla behövde dessa teorier sättas in i ett sammanhang, och den erfarenhetsbaserade kunskapen och kunskapen om elevgruppen gjorde detta möjligt. Det tredje begreppsparet är det personliga och det intellektuella. Den personliga erfarenheten och upplevelsen kan bidra genom att bland annat rikta fokus mot delar som är väsentliga i undervisningssituationen, och när de kombineras med det intellektuella kan analysen av dessa fördjupas. Analysprocessen både breddas och fördjupas genom växlingen mellan närhet och distans. Det fjärde begreppsparet är det partikulära och det universella. I en klinisk forskningsmetod undersöks det partikulära på djupet, men det kan i en abduktiv process ge resultat som är universella. Resultat i form av kritiska aspekter kan användas även utanför det sammanhang där de framkom.

Slutsatsen i artikeln är att olika kunskapskulturer sammanvävs i en praktiknära forskningsansats, och att denna sammanvävning kan göra att resultaten fördjupas och blir relevanta för lärare. 


\section{DISKUSSION}

Huvudfrågan i denna avhandling är hur kunnandet att skriva berättelser kan göras undervisningsbart. Det är en fråga som är direkt kopplad till läraryrket. Lärares huvudsakliga uppdrag är att skapa en undervisning som möjliggör att eleverna utvecklar vissa kunnanden, och i den processen är lärares PCK avgörande (se Shulman, 1986). För att undervisningen ska bli kraftfull behöver innebörden i själva kunnandet avtäckas, dels i relation till hur eleverna erfar det, dels i relation till hur det beskrivs i ämnesdisciplinen (se Pang \& Ki, 2016). Det avgränsade kunnande som har undersökts i denna avhandling är inriktat mot att skriva ett utvecklat händelseförlopp i berättelser. Avhandlingens bidrag handlar om djupanalysen av ett specifikt kunnande och av hur undervisningen av just detta kunnande kan utvecklas. Bidraget kan ses som en del i ett större kunskapsbygge om undervisning $\mathrm{i}$ berättelseskrivande, men det visar också hur ett kunnande kan undersökas, beskrivas och utvecklas med Learning study som metod.

Avhandlingens resultat är både ämnesdidaktiskt och metodologiskt. Båda dessa komponenter vävs in, i olika utsträckning, i nedanstående diskussion. Diskussionen tar sin utgångspunkt $\mathrm{i}$ avhandlingens huvudsakliga frågeställning: Hur går det att göra kunnandet att skriva berättelser undervisningsbart? Utifrån frågeställningen diskuteras tre områden. Diskussionen riktas inledningsvis mot det ämnesdidaktiska resultatet och lyfter sådant som handlar om att undervisa $i$ berättelseskrivande. Därefter förs en diskussion om hur de ämnesdidaktiska resultaten har kunnat genereras baserat på hur forskningspraktiken möjliggör att avtäcka ett kunnande. Det sista området berör både metod, teori och det ämnesdidaktiska innehållet; diskussionen som förs där handlar om att göra det osynliga synligt. Hela diskussionskapitalet avslutas med en framåtblick och förslag på fortsatt forskning.

\section{Undervisa i berättelseskrivande}

Baserat på variationsteorietiska antaganden behöver vi söka efter kritiska aspekter och synliggöra dem i undervisningen för att öka elevernas möjlighet till lärande (Marton, 2015; Pang \& Ki, 2016). Resultatet i denna avhandling visar att kunnandet att skriva berättelser med ett välutvecklat händelseförlopp främjas om aspekterna läsarperspektiv och berättelsestruktur tillgängliggörs i undervisningen.

\section{Möjliggöra erfarande av läsarperspektiv}

Elevers erfarande av läsarperspektivet har betydelse för deras skrivalster (Thorsten, 2014; Thorsten, accepterad). Beaktandet av en läsare verkar vara en skiljelinje som även framkommer i tidigare forskning. Scardamalia och Berieters (1987) modell över skrivande lyfter fram distinktionen mellan om skribenten be- 
aktar den retoriska aspekten eller inte. De framhåller att en mogen skribent funderar över hur innehållet ska förmedlas till en mottagare, medan en omogen skribent inte medvetet planerar sitt skrivande och inte heller reflekterar över hur en läsare tar emot det skrivna. Även andra forskare har påtalat detta (till exempel Durán, 2017; Norberg Brorsson, 2007; Riley \& Reedy, 2005). Bidraget i den här avhandlingen fördjupar och breddar kunskapen om hur läsarperspektivet kan synliggöras i undervisningen och vad elever som inte riktar sig till en läsare fokuserar på i stället.

För yngre barn är det en utmaning att föreställa sig vad en tänkt läsare behöver ha för information för att kunna förstå texten (Riley \& Reedy, 2005). Kan vi utgå från att alla elever ens har en tänkt läsare framför sig när de skriver? Troligtvis inte. Martre (2013) visar i sin fallstudie att elever ibland väljer att snarare skriva för sin egen skull än för andra läsare. Då blir syftet att fantisera och underhålla sig själv, vilket är synligt i vissa elevtexter även i föreliggande studie. I Martres beskrivning väljer eleven själv medvetet olika syften för sitt skrivande, men det kan också tänkas vara ett mer omedvetet val hos eleverna. I Thorsten (2014) och Thorsten (accepterad) framkommer att läsarperspektiv kan uppfattas och hanteras på olika sätt. Troligen är det för elever i 9-10-årsåldern oftast spontana och delvis omedvetna uppfattningar, snarare än medvetna val.

Iser (1972/1974) beskriver att det i texter av etablerade författare finns en implicit läsare. Den implicita läsaren är inte en konkret person utan snarare en abstrakt föreställning av en tänkt läsare. Denna abstraktion kan vara svår för yngre elever och Durán (2017) påtalar att deras skrivande främjas om de har konkreta mottagare att rikta sig till. En specifik, tänkt mottagare gör att eleverna tvingas gå bortanför sin egen fantasi och sina egna tankar (Durán, 2017). I skolan är det därför vanligt att arbeta med reella mottagare, eftersom det antas påverka både motivation och skriftlig förmåga. Även om detta är viktigt visar resultatet i denna avhandling att eleverna också kan behöva undervisning i hur det är möjligt att rikta sig mot en mer ospecifik abstraktion av en läsare. De flesta texter som elever ska producera högre upp i åldrarna ska stå för sig själva och kunna läsas av flera olika läsare. Däremot är det tveksamt om flertalet elever klarar att göra denna abstraktion redan i 9-10-årsåldern. Enligt Christie och Derewianka (2008) utvecklas den skriftspråkliga kompetensen mycket i dessa åldrar, och det kan tänkas att det därför är särskilt viktigt att fortfarande ha hjälp av en konkret läsare. På så sätt är det möjligt att befästa den dekontextualisering (se Alamargot \& Fayol, 2009; Ong, 1982) som krävs i skrivandet.

I den fenomenografiska analysen (Thorsten, 2014; accepterad) framkom två kategorier där eleverna fokuserar på annat än på en läsare (berättelsen som fantasi och berättelsen som att ge karaktären en ideal upplevelse). I berättelsen som fantasi framstår det i utsagorna som att eleven verkar befinna sig i en fantasi och ger ett axplock ur den i sitt skrivalster (Thorsten, 2014). Detsamma kan tänkas vara fallet för texter som är uppbyggda på det sätt som beskrivs i kategorin skapa action 
(Thorsten, accepterad). Det finns luckor i berättandet och det framkommer lösryckta bilder, och troligtvis har eleverna en rikare fantasi än den som framkommer i den skriftliga berättelsen. Det som de skriver i texten skulle kunna liknas vid klipp från virtuella fantasivärldar. Många barn tillbringar också mycket tid fram dator- och tv-spel (Lenters, 2016), och det är rimligt att det påverkar deras skrivande. Lenters (2016) visar i sin studie hur den virtuella datorvärlden kan påverka elevers skrivande i valet av både karaktärer och händelseförlopp. Handlingen i datorspel byggs ofta upp runt faror som oväntat dyker upp, många gånger från ingenstans, och som hjälten ska bemästra. I kategorin skapa action (Thorsten, accepterad), har texterna starka dramatiska inslag med just det upplägget.

Läsarperspektivet är kopplat till skrivande, men mottagare existerar även i andra modaliteter, exempelvis i teater. I resultatet framkommer att det finns en vinst med att inte bara koppla förmågan att byta perspektiv till skrivandet. Genom att bädda in aspekten i ett bredare mottagarperspektiv i form av dramatiseringar, kunde eleverna fokusera på hur andra människor förstår och tar emot deras berättelser (Thorsten, 2014). Eleverna hade då den reella mottagaren direkt framför sig. På en grundläggande nivå handlar det om att vara medveten om en mottagare och kunna växla perspektiv. Detta är fortfarande svårt för många elever i 9-10-årsåldern, vilket gör att det är viktigt att synliggöra det i undervisningen. Marton (2015) menar att varje förmåga är kopplad till ett innehåll. I detta fall handlar det om att byta perspektiv från sig själv som skribent (eller aktör) till att förstå hur mottagaren kan ta till sig berättelsen. Det skulle vara intressant att jämföra med andra ämnesområden där byte av perspektiv är viktigt och se vilka likheter och skillnader som föreligger i denna förmåga, beroende på ämnesinnehåll.

\section{Möjliggöra urskiljande av den narrativa strukturen}

Den narrativa grundstrukturen, bestående av inledning, komplikation och lösning (Chatman, 1978), syns i olika utsträckning och på olika sätt i elevernas alster. I datamaterialet framkommer flera sätt att hantera den narrativa grundstrukturen, allt ifrån att inte ha någon sådan struktur alls till att ha en väl utvecklad narrativ struktur.

I de alster som finns i kategorin beskriva händelser (från Thorsten, accepterad) är den narrativa strukturen inte synlig. Dessa texter saknar den intrig som är karakteristisk för berättelser. Samma sak gäller för kategorin berättelsen som att ge karaktären en ideal upplevelse (från Thorsten, 2014). Nordlund (2016) visar att elever som utvecklas textmässigt inom flera områden mellan årskurs 1och 3 , inte alltid gör det när det gäller den narrativa strukturen. Möjligen har den grundläggande narrativa strukturen inte varit ett tillräckligt tydligt undervisningsinnehåll. I skolpraktiken beskrivs vanligen berättelser med termer såsom inledning, handling och avslut, men utan att problematisera vad handling eller händelseförlopp innebär. Detta blev tydligt vid genomförandet av denna Learning study, då vi i den första cykeln inte synliggjorde vad ett händelseförlopp är och hur det byggs upp. Det innebar att det kunnande vi ville att eleverna skulle lära sig delvis var dolt och 
snarast en outtalad förväntan. Yassin Falk (2017) beskriver hur lärares outtalade förväntningar påverkar elevernas skrivalster och att det krävs ett metaspråk för att kunna tala om skrivandet. Detta bekräftas även av föreliggande studie, men för att detta metaspråk ska skapas krävs att lärarna själva är klara över vad kunnandet innebär och vad eleverna behöver lära sig. I samband med att kunnandet alltmer preciserades i den cykliska processen i studien, skapades också en begreppsapparat för att tala om det tillsammans med eleverna.

En stor grupp elever hade skrivit berättelser som hamnade i kategorin lösa problem. I den kategorin finns den narrativa grundstrukturen med, men den är uppbyggd nästan enbart av kärnhändelser och har endast ett fătal sidohändelser (baserat på Chatmans, 1978, terminologi). Kategorin har stora likheter med det sätt som 6-8-åringar berättar, som det beskrivs av McKeough (1984; 1987). Berättelsen har då ett problem, men det löser sig väldigt snabbt. En utmaning ligger i att hjälpa dessa elever att utveckla sina texter vidare, både genom att bygga upp en större ramstruktur och genom att fylla på med fler detaljer som gör berättelsen rikare. Enligt Case och McKeough (1990) och Jarvey et al. (2008) utvecklas elevernas berättelser som mest om läraren har en undervisning som ligger på barnens nästa kognitiva utvecklingsnivå (baserat på Piagets utvecklingssteg). Även med variationsteorin som utgångspunkt är undervisningen anpassad till var eleverna befinner sig i sitt lärande - dock inte utifrån förutbestämda utvecklingsnivåer, utan snarare baserat på en analys av elevernas kunnande. På vissa sätt sammanfaller de kritiska aspekterna i denna studie med de aspekter av berättelseskrivandet som McKeough (1984; 1987) och McKeough och Genereux (2003) menar att en 8-åring, en 10åring eller en 12-åring behärskar. Det är antagligen rimligt att vissa delar i skrivandet är särskilt lämpliga att utveckla i just 9-10-årsåldern. Det verkar som att barn i den här åldern spontant fokuserar på berättelsens händelseförlopp och att det därför är särskilt lämpligt att utveckla just denna del i skrivandet.

När vi i forskningslektionerna uttalat synliggjorde den kritiska aspekten $u r$ skilja att ett huvudproblem och dess lösning kan bestå av flera delproblem och lösningar, visade det sig påverka och utveckla elevernas skrivande i stor utsträckning, särskilt förmågan att utveckla berättelsestrukturen (Thorsten, 2014). Strukturen med problem och lösning fungerade som det Riley och Reedy (2005) benämner som planeringsram. Risken med denna typ av verktyg är dock att de i alltför stor utsträckning fungerar mekaniskt. Vid undervisningen är det därför viktiga att främst fokusera på att eleverna ska få möjlighet att urskilja nya aspekter, och på så sätt få nya insikter som kan ligga till grund för det egna skrivandet. Dessa insikter kan inledningsvis behöva stöttas upp med hjälp av planeringsramar. Dessa ramar fungerar då som ett stöd och komplement till annan undervisning, snarare än som en mekanisk skrivmanual.

Ett av resultaten i föreliggande avhandling (i Thorsten, 2014 och Thorsten, accepterad) är att många elever hade svårt att skapa sammanhängande berättelser. Även Berninger et al. (1996) och Sanders och Schilperoord (2006) påvisar att det är en utmaning för elever i denna ålder att skapa texter som kopplas samman på 
både den lokala och den globala nivån. Den kritiska aspekten urskilja att problemen och lösningarna ska vävas samman till en trovärdig helhet utifrån berättelsens logik, handlar om just detta. Aspekten hanterades i undervisningen, men fokuserade mest på den lokala nivån. Efterbedömningen visade att eleverna förbättrade sin förmåga att skriva sammanhängande texter, men detta är ett område som skulle kunna utvecklas ytterligare i undervisningen. Det gjordes inga tydliga kontraster som berörde kopplingen mellan textens lokala och globala nivå. Det var heller inget som forskningsgruppen diskuterade.

Aspekten urskilja av utrymme är nära sammanlänkad med aspekten om sammanhang (Thorsten, accepterad). Denna aspekt hanterades inte alls på forskningslektionerna men analysen av elevtexterna i Thorsten (accepterad) visade tydligt att detta var en aspekt som påverkade elevernas skrivande. Genette (1972/1980) använder begreppet duration, och beskriver att det handlar om hur mycket utrymme olika händelser i storyn får i diskursen. Detta påverkar rytmen och drivet i berättelsen. Det är dock en utmaning för eleverna att urskilja och förstå vilka detaljer som är intressanta att fördjupa sig i och vilka som helt kan förbises. Det är heller inte ett område som brukar fördjupas i undervisningen, men det skulle vara intressant att studera i fortsatta studier.

\section{Avtäcka ett kunnande - forskningspraktikens betydelse}

Kunnandet att skriva berättelser är något som vi kan anta att alla lärare känner till, eftersom berättande är en så stor del av vår kultur (se Ong, 1982; Bruner, 2002). Lärare har antagligen både skapat egna berättelser och mött berättelser i olika former i skolan, under utbildningen och i privatlivet. Erfarna svensklärare har dessutom undervisat $\mathrm{i}$ berättelseskrivande. Trots detta kan det vara svårt att fånga och beskriva vad själva kunnandet innebär, och mer specifikt vad det innebär att kunna skriva berättelser med ett välutvecklat händelseförlopp samt hur det går att undervisa så att eleverna utvecklar detta kunnande. I den här avhandlingen har det undersökts hur forskningspraktiken i Learning study kan göra det möjligt att undersöka och utveckla kunnande i berättelseskrivande. Frågan är vad det är i metoden Learning study, i kombination med variationsteori, som gör att det går att generera den typ av resultat som diskuterades i avsnittet innan.

Metoden innehåller flera komponenter som kan tänkas ha betydelse. För det första finns ett fokus på ett lärandeobjekt (Lo, 2012). Hela processen riktas därför mot att undersöka ett specifikt kunnande, hur det erfars av eleverna och hur det går att göra undervisningsbart. Det handlar om kunskap inom PCK (se Shulman, 1986), det vill säga ämnesdidaktisk kunskap. Resultat i föreliggande avhandling visar att hela begreppsapparaten i Learning study och variationsteori medverkar till att fokusera lärandeinnehållet (Thorsten, 2015). Liknande resultat påvisas i Mårtenssons (2015) studie. Variationsteorin i kombination med Learning study gör 
det möjligt att mikroanalysera ett kunnande och studera vilka detaljer som har avgörande betydelse för hur lärandeobjektet framkommer i undervisningen. Begrepp såsom urskiljande, andra ordningens perspektiv och kritiska aspekter riktar fokus mot elevers förståelse och lärande av ett undervisningsinnehåll. Det är just relationen mellan undervisning, undervisningsinnehåll och elevernas lärande som variationsteorin ger redskap för att belysa (Runesson, 2017).

I Learning study-processen används lärarerfarenheten som en resurs (Thorsten, 2015; 2017). Synen på lärares deltagande i forskning är nära sammankopplad med synen på forskningspraktik och på om forskningspraktiken genomsyras av ett inifrån- eller utifrånperspektiv.

\section{Inifrån- och utifrånperspektiv i forskningen}

Synen på forskarrollen och praktikerrollen påverkar forskningspraktiken (Carlgren, 2017). I traditionell akademisk forskning har ofta den objektiva blicken eftersträvats, vilket gör att ett utifrånperspektiv länge var rådande (Bulterman-Bos, 2008; Stenhouse, 1981). I en forskningspraktik likt Learning study kan dock ett inifrånperspektiv vara en tillgång. Den strikta uppdelningen mellan forskare och praktiker luckras då upp, eftersom forskningsfrågorna är gemensamma. Bulterman-Bos (2008) för ett teoretiskt resonemang runt att detta är möjligt. Resultaten i avhandlingen (se Thorsten, 2017) visar, med stöd i empiri, att det går att väva samman forskarpraktiken och lärarpraktiken. I en sådan sammanvävning (benämnd som klinisk forskning av Bulterman-Bos, 2008, och Carlgren, 2012) har lärarblicken betydelse vid både genomförande och analys. Bulterman-Bos (2008) påtalar att det behövs en "mästare" för att bedöma en praktik, och i detta fall är mästaren en mycket kunnig och erfaren lärare. Bulterman-Bos har onekligen en poäng: Vi skulle inte låta en bibliotekarie bedöma ett hantverksutförande i trä; det skulle vi lämna åt en snickare som kan avgöra vilka detaljer som är särskilt viktiga att fokusera på vid ett gott hantverk, detaljer som kan vara dolda för personer utan den kompetensen. I resultatet framkommer att lärare uppfattar små, subtila signaler från eleverna och att de därför gör val som driver undervisningen framåt (Thorsten, 2017). Detsamma gäller vid analysen; lärarblicken kan göra att intresset riktas mot delar som har särskild betydelse för elevers lärande. Liksom all yrkeserfarenhet går lärarerfarenheten inte att enbart läsa sig till. Den går inte att få på annat sätt än att befinna sig i (eller "dwelling" som Polanyi, 1962, skriver) flera olika situationer som är specifika för yrket.

Det finns dock kritik mot att lärare forskar. Hattie (i Stewart, 2015) har i en intervju uttalat sig om att lärare inte ska vara forskare och att forskningen ska lämnas åt akademikerna. Lärare ska därmed fokusera på det praktiska och forskarna på det teoretiska. Ett starkt skäl till detta är, enligt Hattie, att forskningen kräver förmågor som det tar år att utveckla. Detta är något som även Labaree (2003) lyfter fram. Han menar att det krävs kunskap och särskilda förmågor för att genomföra studier på ett systematiskt och transparent sätt, och att den typen av kunskap inte utvecklas spontant i lärares arbete. Hatties och Labarees beskrivningar kan tolkas 
som att de står för en strikt uppdelning mellan skola och akademi och mellan praktik och teori. En sådan uppdelning behöver dock inte vara nödvändig om forskningspraktiken bygger på att lärares erfarenhetsbaserade kunskap är viktig i genererandet av ny kunskap. Innebär detta att det räknas som forskning så fort lärare genomför någon form av undersökning i sin egen praktik? Jag vill hävda att det inte heller är så enkelt. Pring (2006) framhåller att studier som genomförs av lärare måste ha samma vetenskapliga krav som andra studier. De måste tåla kritisk granskning och ge ett bidrag som är intressant utanför den specifika kontext där de genomfördes. Därför har Hattie (i Stewart, 2015) en poäng när han menar att det krävs en särskild kompetens för att forska. I detta sammanhang blir det därför intressant att lyfta fram skillnaden mellan en lärare som forskar och en forskarutbildad lärare som forskar. Vilken kompetens forskarutbildningen ger beror mycket på vilken forskningspraktik skolningen har skett i, eftersom olika forskningspraktiker står för olika typer av metoder och teorier. I vissa traditionella akademiska forskningspraktiker uppmanas ofta den forskande läraren att bortse från sin lärarerfarenhet, i andra mer praktiknära traditioner kan erfarenheten istället ses som en tillgång. Då blir tillägnandet av metoder, teorier och vetenskapligt förhållningssätt ett komplement till den erfarenhetsgrund läraren har med sig. Lampert (1990) beskriver att analysen kan fördjupas när samma individ har både lärarerfarenhet och kunskap om lämpliga forskningsmetoder och teorier.

Labaree (2003) menar att lärare som börjar forska möter särskilda utmaningar. Hans beskrivning kan tyckas vara för långtgående och hårdragen, men han fångar vissa grundläggande skillnader mellan forskningspraktiken och lärarpraktiken som den forskande läraren behöver förhålla sig till. Problemet med Labarees (2003) beskrivning är att han framställer det som att gå från det ena till det andra och att det förhållningssätt som karakteriserar lärarpraktiken blir ett hinder i forskningen. I traditionell utifrånforskning, som bygger på en tanke om den "objektiva forskaren", kan hans resonemang ha bäring. Om utgångspunkten istället är att forskarens erfarenheter och kunskaper om området som beforskas kan ha avgörande betydelse för tolkning och analys (vilket bland annat Bulterman-Bos, 2008 och Pring, 2006, hävdar), handlar det snarare om att vara medveten om vilka tillgångar och hinder det innebär att ha en lärarerfarenhet med sig in i forskningsprocessen. Erfarenheten blir ett filter varigenom data betraktas, vilket möjliggör ett relevant professionsfokus, men det finns också risk för att vissa delar blir dolda. Det är en av anledningarna till att teorianvändande blir viktigt. Det kan göra att inifrånperspektivet kompletteras med ett utifrånperspektiv eftersom teorin erbjuder alternativa glasögon och filter. I Thorsten (2017) visas att de teoretiska glasögonen möjliggör en växling mellan närhet och distans. Den teoretiska analysen kompletterar en analys som baseras på erfarenhet och upplevelser.

Givet att lärares erfarenhet har betydelse i forskningsprocessen, betyder det att endast de med lärarerfarenhet borde forska i skolan? Nej, så behöver det inte vara. En mångfald av infallsvinklar, perspektiv och metoder behövs i forskningen och forskare med skiftande bakgrund kan bidra med väsentlig skolforskning, men på 
olika sätt. Forskningsintresset har betydelse för vem som är lämpad att genomföra olika typer av studier i relation till skolan. Forskning som avser att undersöka och utveckla ett kunnande är inriktad mot undervisning och då har lärarerfarenheten betydelse i hela processen (Thorsten, 2015; 2017). I en sådan forskningsprocess finns det fördelar med ett samarbete med forskare med lärarerfarenhet och forskare som har djup ämnesdisciplinär kompetens, eftersom synen på och förståelsen för ämnesinnehållet påverkar hur det hanteras i undervisningen (se Gudmundsdotir, 1991; Shulman, 1986). De kritiska aspekterna är relaterade både till elevers sätt att hantera kunnandet, och till den ämnesdisciplinära beskrivningen av kunnandet (Pang \& Ki, 2016). Ett samarbete mellan forskare med olika bakgrund och kompetens, tillsammans med verksamma lärare, kan därför vara fruktbart för att utveckla ny kunskap om kunnanden.

\section{Iterativ design - i en dynamisk och komplex klassrumskontext}

En aspekt som inte uttryckligen behandlas i artiklarna är hur det iterativa upplägget har påverkat forskningsprocessen. Det är iterativiteten som möjliggör den utforskande processen i vilken både lärarerfarenheten och variationsteorin blir redskap. Detta kan liknas vid Morris och Hieberts (2011) beskrivning av småskaliga undersökningar som fokuserar på små betydelsefulla förändringar. I föreliggande avhandling framkommer att lärandeobjektet specificeras $i$ den iterativa processen (Thorsten, 2014; 2015; 2017). Elevers reaktioner och kommentarer i undervisningssituationen ger ledtrådar till innebörden av kunnandet, och deras olika sätt att hantera uppgifterna på kan ge nya insikter om vilka aspekter som är kritiska. Liknande resultat framkommer i Mårtensson (2015). Där visas hur lärare alltmer specificerar och definierar lärandeobjektet när de deltar i Learning study. Carlgren (2017) framhåller att det är i interaktionen mellan lärare, elever och det aktuella lärandeinnehållet, alltså i själva iscensättandet, som kunnandet kommer till uttryck och blir möjligt att studera. Således är det när en undervisningsdesign testas i den dynamiska och komplexa skolmiljön som kunnandet avtäcks och blir synligt för forskaren. I den cykliska processen framträder då allt fler dimensioner av det kunnande som undersöks. Det blir en abduktiv process där framväxande substantiva teorier om kunnandet hela tiden jämförs med nya observationer (se Stiles, 2009). I processen preciseras både lärandeobjektet och de kritiska aspekterna.

Det iterativa upplägget innebär inte bara att testa undervisningsdesignen flera gånger, utan mellan varje cykel görs förändringar i designen i syfte att förbättra den. Morris och Hiebert (2011) framhåller att det är de små förändringarna som kan ha avgörande betydelse i en undervisningssituation. Vilka förändringar som behöver göras går att se $\mathrm{i}$ en analys som är baserad på en kombination av lärarerfarenhet och teorianvändande. I Thorsten (2017) framkommer att inte bara den generella lärarerfarenheten har betydelse, utan även erfarenheten av att iscensätta det aktuella lärandeobjektet och de aspekter som hypotetiskt är kritiska. Erfarenheten efter att ha undervisat i till exempel berättelseskrivande kan bestå av en intuition eller känsla av att vissa delar i lektionerna har särskild betydelse för hur 
eleverna kan införliva kunnandet. När den känslan kombineras med användandet av variationsteori öppnar det för att hitta hur de kritiska aspekterna kan tillgängliggöras på delvis andra sätt. Teorin och lärarerfarenheten blir basen för analysen, men utan iterativiteten skulle det inte gå att undersöka hur förändringar i iscensättandet av undervisningen påverkar elevernas lärande. Iterativiteten gör att olika iscensättanden kan jämföras med varandra. De skillnader som framträder mellan olika forskningslektioner öppnar för att få syn på nya aspekter som kan tänkas vara kritiska för att eleverna ska utveckla det avsedda kunnandet. Variationsteorin fungerar som teoretiskt redskap både för att hitta de kritiska aspekterna (via kontraster mellan lektioner) och för att i undervisningen synliggöra de kritiska aspekterna för eleverna. Således kan grundantagandet om att vi lär oss nytt genom att se skillnader (se Marton, 2015) vara applicerbart på såväl forskningsprocess som undervisning.

\section{Göra det osynliga synligt}

Analysen av kunnandet att skriva berättelser medverkar till att avtäcka kunnandet och göra osynliga aspekter synliga. Därmed inte sagt att det är möjligt att fullständigt beskriva ett kunnande. Polanyi (1962a) menar att en del i den tysta kunskapen är omöjlig att verbalisera. Den syns bara i det sätt i vilket en mästare utför det. I undervisningssammanhang är det dock centralt att försöka göra ett kunnande synligt, inte nödvändigtvis bara verbalt.

\section{Synliggöra via kontraster}

Centralt i variationsteorin är att synliggöra kritiska aspekter genom att skapa kontraster (Marton, 2015). Grundantagandet är att vi lär oss nytt genom att se skillnader; därmed blir kontrasten det som gör det möjligt att urskilja nya aspekter. För att kunna skapa kraftfulla kontraster behöver läraren förstå både hur eleverna erfar lärandeobjektet och vilket kunnande som är önskvärt att eleverna utvecklar. Min erfarenhet från min egen lärartid, från egen forskning och från observerade lektioner är att lärare ofta säger till eleverna vad de behöver tänka på i sitt skrivande. Till exempel kanske lärare uppmanar eleverna att skriva tydligare, så att en läsare kan förstå texten (det vill säga påtala läsarperspektivet). Däremot är det inte lika vanligt med en undervisningsdesign som behandlar denna typ av aspekt som ett undervisningsinnehåll. Resultatet i den här avhandlingen visar att detta är möjligt. Det går att explicit undervisa om läsarperspektivet och det går att synliggöra det med hjälp av kontrasterande exempel. Det behöver inte ske på just det sätt som gjordes i studien, men poängen är att det är skillnad på att bara säga något och på att synliggöra det, och kontrasten blir ett sätt att möjliggöra ett urskiljande hos eleverna.

Det är en utmaning att hitta de kontraster som synliggör precis det vi vill att eleverna ska lära sig. I många tidiga texter om variationsteorin beskrivs kontrast som att visa vad något inte är (se till exempel Marton \& Tsui, 2004). I senare texter 
(se Marton, 2015) framkommer tydligare att det handlar om att öppna upp en dimension av variation genom att visa olika värden i dimensionen. Att visa vad något inte är innebär alltså inte att vi kan välja vad som helst som skiljer sig från det vi vill ha fram. Vilka värden som väljs ut för kontrast beror på vad som vi specifikt vill göra urskiljningsbart, och det bygger på en grundlig analys av var eleverna befinner sig i sitt lärande. Kontrasten mellan ett välutvecklat och ett torftigt händelseförlopp visar vad som saknades i elevernas berättelser (Thorsten, 2014). Även andra kontraster användes på ett framgångsrikt sätt i undervisningen. Ju mer kunskap vi får om lärandeobjektet, desto mer exakta kan vi bli i de kontraster som används. Det räcker dock inte med att förstå vilka värden som behöver kontrasteras. Resultatet (Thorsten 2015; 2017) visar att de valda kontrasterna behöver bäddas in i ett material som är både lämpligt och inspirerande för den aktuella åldersgruppen. Det är också nödvändigt att analysera kontrasten tillsammans med eleverna för att de ska få en djupare förståelse av lärandeobjektet (Thorsten, 2014).

Under forskningsprocessen har mina kunskaper om variationsteori och berättelseskrivande fördjupats, och i vissa fall framträder nu andra aspekter och andra möjliga kontraster som hade kunnat utforskas i studien. Thorsten (accepterad) bidrog med fördjupad kunskap om hur eleverna erfor lärandeobjektet. Denna kunskap skulle kunna bidra till att undervisningen i berättelseskrivande utvecklas ytterligare. Det är en ständigt pågående utforskande process, vilket gör att det går att fortsätta det iterativa upplägget och ytterligare undersöka hur kunnandet att skriva berättelser går att göra undervisningsbart.

\section{Explicit och implicit undervisning}

Variationsteorin ger redskap för att explicit undervisa om ett kunnande. Enligt Mason (2011) är det dock viktigt att undervisningen har både explicita och implicita inslag. Polanyis (1962a) beskrivning av hur ett kunnande utvecklas kan liknas vid en implicit process, eftersom en kompetent utövare lär sig bli kompetent just genom att befinna sig i situationer där kunnandet utövas. I skrivundervisningen har det varit en pågående diskussion om huruvida skrivande bäst lärs via explicit eller implicit undervisning (Blåsjö, 2010; Ivanič, 2004). I grunden handlar det om ifall undervisningen uttalat ska synliggöra det som eleverna ska lära sig, eller om kunnandet snarare ska finnas inbäddat $i$ aktiviteter och att eleverna då lär sig genom att delta i dessa aktiviteter som gärna ska vara kreativa och/eller som ska likna en naturlig praktik.

Marton (2015) framhåller att lärande hela tiden sker i vardagen i naturliga sammanhang, när barn deltar och interagerar med andra. Lärandet kan då ses som en biprodukt. Denna typ av lärande kan naturligtvis också ske i skolan. Men eftersom en mängd olika innehåll ska läras i skolan, behövs oftast explicit undervisning för att eleverna ska ha möjlighet att utveckla det avsedda kunnandet fullt ut. Vid en variationsteoretisk undervisning vet läraren vad eleverna ska lära sig och variationsmönster används som ett sätt att tillgängliggöra de kritiska aspekterna för eleverna (Marton, 2015). 
Går antaganden om att kritiska aspekter explicit behöver synliggöras i undervisningen att kombinera med mer implicita sätt att se på skrivundervisning? Det kan handla till exempel om att eleverna lär sig genom att delta i en praktik som genomsyras av det kunnande som eleverna ska förvärva, eller en undervisning som innehåller fritt skrivande och eget utforskande. Antagligen är det nödvändigt med en kombination av explicita och implicita inslag i skrivundervisningen. Holmberg (2014) beskriver att elever kan ha god implicit kunskap om den fiktiva genren och att den har utvecklats genom eget läsande och skrivande. Både Holmberg (2014) och Yassin Falk (2017) påtalar att även om elevens implicita kunskap kan vara en tillgång behöver läraren vara tydlig med sina förväntningar när det gäller till exempel struktur och språk.

De kritiska aspekter som identifierades och synliggjordes i studien är exempel på just en sådan riktad undervisning. Dunn och Finley (2010) och Graham (2006) har visat att särskilt elever med ett svagt språk har nytta av denna typ av undervisning. I Thorsten (2014) visas dock att de allra flesta eleverna utvecklade sitt skrivande efter interventionen, oavsett hur välutvecklad text de skrev i förbedömningen. Detta indikerar att även elever med förhållandevis god språklig förmåga kan utveckla sitt skrivande ytterligare när de erfar nya kritiska aspekter. För att eleverna ska erfara kritiska aspekter behöver dessa aspekter komma fram i ett sammanhang som upplevs som både relevant och lustfyllt. Att skriva fritt utifrån lust och intresse i ett sammanhang där skrivandet har en naturlig funktion, behöver alltså inte motsäga att eleverna också får riktad undervisning i berättelseskrivande.

\section{Slutord}

Avhandlingen har visat hur det går att göra kunnandet att skriva berättelser undervisningsbart, både genom att visa hur själva kunnandet kan avtäckas i en forskningsprocess och hur synliggörandet av kritiska aspekter kan göra att eleverna utvecklar det avsedda kunnandet. De resultat som har påvisats här kan ses som del i främst två större forskningsfält: metodologisk forskning om praktiknära forskningsmetoder och forskning inom det svenskdidaktiska fältet. Det finns fortfarande mycket kvar att göra. Kunnande i berättelseskrivande låter sig inte beskrivas och undersökas fullt ut i denna avhandling, men den bidrar med viktiga pusselbitar till vad som konstituerar kunnandet. I ytterligare studier kan detta preciseras vidare. Det skulle vara fullt möjligt att fokusera på samma lärandeobjekt och gå ännu djupare. Det skulle också, som jag redan nämnt, vara intressant att arbeta med det Genette (1972/1980) benämner duration, alltså varaktighet. Vad är det vi ger utrymme i berättelsen; vad tar vi upp kortfattat och vad är det vi dröjer oss kvar vid? Det är ett område som har berörts i denna avhandling, men som skulle tjäna på att fördjupas.

När det gäller forskning om den praktiknära forskningen har denna avhandling bidragit med ett inifrånperspektiv. Genom att i Thorsten (2017) visa på att Labarees (2003) dikotomier kan upplösas blev det möjligt att visa att en kultur inte 
behöver ersätta en annan. Olika kunskapskulturer kan samverka och skapa en helt annan praktik än den traditionella akademiska praktiken eller skolpraktiken. Fler studier skulle dock behövas för att undersöka kunskapen hos lärare, forskare respektive forskande lärare i denna typ av processer. Avslutningsvis vill jag lyfta fram vikten av att göra ett kunnande undervisningsbart. Det finns många delar $\mathrm{i}$ undervisningen som vi låter vara osynliga för eleverna, men om de görs synliga ökar möjligheten till lärande. Detta innebär dock inte att berättelseskrivande (och andra kunnanden) ska reduceras till något tekniskt och instrumentellt. Magin och glädjen i berättandet skapar mening och motivation till att skriva. Kunnande i berättelseskrivande går att avtäcka, men inte fullt ut. 


\section{REFERENSER}

Ahlstrand, P. (2014). Att kunna lyssna med kroppen: En studie av gestaltande förmåga inom gymnasieskolans estetiska program, inriktning teater. (Doktorsavhandling). Stockholm: Stockholms universitet.

Alamargot, D. \& Fayol, M. (2009). Modelling the development of written composition. I R. Beard, D. Myhill, M. Nystrand \& J. Riley (Red.), The SAGE Handbook of Writing Development. SAGE publications Ltd (e-bok).

Arhar, J., Niesz, T., Brossmann, J., Koebley, S., O’Brien, K., Loe, D. \& Black, F. (2013). Creating a 'third space' in the context of a university-school partnership: supporting teacher action research and the research preparation of doctoral students. Educational Action Research, (21)2, 218-236.

Asplund Carlsson, M., Pramling Samuelsson, I., Soponyai, A., \& Wen, Q. (2001). The dog's tale; Chinese, Hungarian and Swedish children's narrative conventions. International Journal of Early Years Education, 9(3), 181-191.

Barbot, B., Tan, M., Randi, J., Santo-Donato, G. \& Grigorenko, E. L. (2012). Essential skills for creative writing: Integrating multiple domain-specific perspectives. Thinking Skills and Creativity, 7(3), 1-15.

Bayat, S. (2016). The effectiveness of the creative writing instruction program based on speaking activites (CWIPSA). International Electronic Journal of Elementary Education, 8(4), 617-628.

Bazerman, C. (2016). What do sociocultural studies of writing tell us about learning to write? I C. MacArthur, S. Graham \& J. Fitzgerald (Red.), Handbook of Writing Research (s.11-23). New York, London: The Gilford Press.

Berninger, V., \& Amtmann, D. (2003). Preventing written expression disabilities through early and continuing assessment and intervention for handwriting and/or spelling problems: Research into practice. I H. Swanson, K. Harris, and S. Graham (Red.), Handbook of Learning Disabilities (s. 323- 344). New York: The Guilford Press.

Berninger, V. W., Fuller, F., \& Whitaker, D. (1996). A process model of writing development across life span. Educational Psychology Review, 8(3), 193-218.

Blåsjö, M. (2010). Skrivteori och skrivforskning. En forskningsöversikt. Stockholm: Institutionen för nordiska språk, Stockholms universitet.

Braun, V. \& Clarke, V. (2006), Using thematic analysis in psychology. Qualitative Research in Psychology, 3(2), 77-101.

Bruner, J. (2002). Making stories: Law, literature, life. New York: Farrar, Straus and Giroux.

Bryman, A. (2011). Samhällsvetenskapliga metoder. Malmö: Liber AB.

Bulterman-Bos, J. (2008). Will a clinical approach make education research more relevant for practice? Educational Researcher, 37(7), 412-420. 
Calkins, L. M. (1995). Skrivundervisning. Mölnlycke: Utbildningsstaden AB.

Carlgren, I. (2011). Kunnande-kunskap-kunnighet (Knower-knowing-the known). I Lindström, L., Lindberg, V. \& Petterson, A. (Red.), Pedagogisk Bedömning. Att dokumentera, bedöma och utveckla kunskap (s. 43-58). Stockholm: Liber.

Carlgren, I. (2012). The Learning Study as an approach for research. International Journal for Lesson and Learning Studies, 1 (2), 3-13.

Carlgren, I. (2015). Kunskapskulturer och undervisningspraktiker. Göteborg: Daidalos.

Carlgren, I. (2017). Forskning som utvecklar undervisningen. I: I. Carlgren (Red.), Undervisningsutvecklande forskning - exemplet Learning study (s. 175-189). Malmö: Gleerups.

Carlgren, I., Ahlstrand, P., Björkholm, E. och Nyberg, G. (2015). The mening of knowing what is to be known. Éducation et didactique, 9(1), 143-160.

Carlgren, I., Eriksson, I. \& Runesson, U. (2017). Learning study. I: I. Carlgren (Red.), Undervisningsutvecklande forskning - exemplet Learning study (s. 17-30). Malmö: Gleerups.

Case, R. \& McKeough, A. (1989). Schooling and the development of central conceptual structures: An example from the domain of children's narrative. International Journal of Educational Research, 13(8), 835-855.

Chandler, G. E. \& Schneider, P. (2009). Creation and response: Wellspring to evaluation. I S. B. Kaufman (Red.), The Psychology of Creative Writing (s. 316-331). New York: Cambridge University Press.

Chatman, S. (1978). Story and discourse. Narrative structure in fiction and film. New York: Cornell University Press.

Cheung, W-M. (2005). Describing and enhancing creativity in Chinese writing. (Doktorsavhandling). Hong Kong: University of Hong Kong.

Christie, F. \& Derewianka, B. (2008). School discourse. New York: Continuum.

Clay, M. M. (1991). Becoming literate. The construction of inner control. Auckland: Heinemann.

Cochran-Smith, M., \& S. Lytle. (1999). The teacher research movement: A decade later. Educational Researcher, 28 (7): 15-25.

Davydov, V. V. ( 2008). Problems of developmental instruction. A theoretical and experimental psychological study. New York: Nova Science Publishers, Inc.

Delpit, L. (2006). Other people's children: Cultural conflict in the classroom. New York: The New Press.

Dewey, J. (1902). Barnet och läroplanen. I Hartman, S. Lundgren, U. \& Hartman, R-M. (2004). J. Dewey: Individ, skola och samhäll: utbildningsfilosofiska texter (106125). Stockhom: Natur \& kultur.

Dewey, J. \& Bentley, A. (1949). The knowing and the known. Boston: Beacon.

Dudley, P. (2013), "Teacher learning in lesson study: what interaction-level discourse analysis revealed about how teachers utilised imagination, tacit knowledge of teaching and fresh evidence of pupils learning, to develop practice knowledge and 
so enhance their pupils' learning". Teaching and Teacher Education, 34 (8), 107 121.

Dunn, M. \& Finley, S. (2010). Children's struggles with the writing process. Exploring storytelling, visual arts, and keyboarding to promote narrative story writing. $R e$ medial and Special Education, 18(1), 33-41.

Durán, L. (2017). Audience and young bilingual writers: Building on strengths. Journal of Literacy Research, 49(1), 92-114.

Elbow, P. (2000). Everyone can write. New York: Oxford University Press.

Elliott, J. (1991). Action research for educational change. Milton Keynes, Philadephia: Open University Press.

Elliott, J. (2012). Developing a science of teaching through lesson study. International Journal of Lesson and Learning Studies, 1(2), 108-125.

Evensen, L. S. (2006). Skriveutvikling. Som stadier, som sprang, som orkestrering? I Matre, S. (Red.), Utfordring for Skriveopplaering og Skriveforsking Idag, (s. 1423). Trondheim: Tapir akademisk forlag.

Fasting, R. B., Thygesen, R., Berge, K. L., Evensen, L. S. \& Vagle, W. (2009). National assessment of writing proficiency among Norwegian students in compulsory schools. Educational Research, 53 (6), 617-637.

Fisher, R. (2006). Whose writing is it anyway? Issues of control in the teaching of writing. Cambridge Journal of Education, 36 (2), 193-206.

Flower, L. \& Hayes, J. R. (1981). A cognitive process theory of writing. College Composition and Communication, 32(4), 365-387.

Frankel, K. K. (2013). Revisiting the role of explicit genre instruction in the classroom. Journal of Education, 193(1), 17-30.

Genette, G. (1972/1980). Narrative discourse. An essay in method. New York: Cornell University Press.

Gibbons, P. (2006). Stärk språket, stärk lärandet. Stockholm: Hallgren \& Fallgren.

Glaser, B. \& Strauss, A. (1967). The discovery of grounded theory: Strategies for qualitative research. New York: Aldine de Gruyter

Gómez, E. S., Sérvan Núnez, M. J., Pérez Gómez, A. I. \& Trapera, N. P. (2015). Lesson study and the development of teacher's competence. International Journal for Lesson and Learning Studies, 4(3), 209-223.

Graham. S. (2006). Strategy instruction and the teaching of writing. I C. MacArthur \& S. Graham (Red.), Handbook of Writing Research (s. 187-207). New York: The Guilford Press.

Graham, S, Harris, K.R. \& Chambers, A.B. (2016). Evidence-Based practice and writing instruction. A review of reviews. I C. MacArthur, S. Graham \& J. Fitzgerald (Red.), Handbook of Writing Research (s.211-226). New York, London: The Gilford Press.

Graham, S. \& Sandmel, K. (2011). The process writing approach: A meta-analysis. The Journal of Education Research, 105(1), 396-407.

Graves, H. D. (1994). Skriv- och läsbefruktning. Göteborg: Daidalos AB. 
Graves, H. D. (2003). Writing. Teachers \& children at work. Portsmouth: Heinemann.

Gudmundsdottir, S. (1991) Ways of seeing are ways of knowing. The pedagogical content knowledge of an expert English teacher. Journal of Curriculum Studies, 23(5), 409-421.

Halliday, M. A. K. \& Matthiessen, C. M.I.M. (2004). An Introduction to Functional Grammar. London: Hodder Education.

Hayes, J. (2006). New directions in writing theory. I C. MacArthur \& S. Graham (Red.), Handbook of Writing Research (s. 28-40). New York: The Guilford Press.

Hayes, J. (2009). From idea to text. I R. Beard, D. Myhill, M. Nystrand \& J. Riley (Red.), The SAGE Handbook of Writing Development (s. 65-80). SAGE publications Ltd. (e-bok).

Henze, I. van Driel, J. H. \& Verloop, N. (2008.) Development of experienced science teachers' pedagogical content knowledge of models of the solar system and the universe. International Journal of Science Education, 30(10), 1321-1342.

Hiebert, J., Gallimore, R. \& Steigler, J. W. (2002). A knowledge base for the teaching profession: What would it look like and how can we get one? Educational Researcher, 31(5), 3-15.

Holmberg, P. (2014). Genre under förhandling. I Boglind, A. Holmberg, P. \& A. Nordenstam, Mötesplatser - texter för svenskämnet (s. 111-129). Lund: Studentlitteratur.

Holmqvist, M. (2011). Teachers' learning in a learning study. Instructional science, 39, 497-511.

Hounsell, D. (1984). Contrasting conceptions of essay-writing. I F. Marton, D. Hounsell \& N. Enwistle (Red.), The Experience of Learning (s. 106-125). Scottish Academic Press.

Iser, W. (1972/1974). The implied reader. Patterns of communication in prose fiction from Bunyan to Beckett. Baltimore, Maryland: Johns Hopkins University Press.

Ivanič, R. (2004). Discourses of writing and learning to write. Language and Education. 18 (3), 220-245.

Janik, A. (1996), Kunskapsbegreppet i praktisk filosofi. Stockholm: B. Östlings Bokförlag Symposion.

Jarvey, M. McKeough, A. \& Pyryt, M. C. (2008). Teaching trickster tales: A Comparison of Instructional Approaches. Research in the Teaching of English. 43(1), 4273.

Johansson, P. \& Thorsten, A. (2017). Experiences from the teacher- researcher's perspective on learning study - Challenges and opportunities. International Journal for Lesson and Learning Studies, 6 (1), 45 - 55.

Labaree, D.F. (2003). The peculiar problems of preparing educational researchers. $E d u$ cational Researcher. 32(4), 13-22.

Lampert, M. (1990). When the problem is not the question and the solution is not the answer: Mathematical knowing and teaching. American Educational Research, 27(1), 29-63. 
Larsson, S. (2005). Om kvalitet i kvalitativa studier. Nordisk Pedagogik, 1(25), 16-35.

Larsson, S. (2009). A pluralist view of generalization in qualitative research. International Journal of Research \& Method in Education, 32(1), 25-38.

Lee Shing, C., Saat, R. M. \& Heng Loke, S. (2015). The knowledge of teaching - Pedagogigal Content Knowledge (PCK). The Malaysian Online Journal of Educational Science, 3(3), 40-55.

Lenters, K. (2016). Riding the lines and overwriting in the margins: Affect and multimodal literacy practices. Journal of Literacy Research, 48 (3), 280-316.

Lewis, C. (2009). What is the nature of knowledge development in lesson study?, Educational Action Research, 17(1), 95-110.

Liberg, C. (2013). Elevers läs- och skrivutveckling - mellanåren. Stockholm: Skolverket. Hämtad den 19 februari 2014 från http://www.skolverket.se/polopoly fs/1.114841!/Menu/article/attachment/Elevers_skriv_och_lasutveckling.pdf

Lo, M. L. (2012). Variation Theory and the improvement of teaching and learning. Göteborg: Göteborgs universitet.

MacArthur, C. \& Graham, S. (2016). Writing research from a cognitive perspective. I C. MacArthur, S. Graham \& J. Fitzgerald (Red.), Handbook of Writing Research (s.24-40). New York, London: The Gilford Press.

Manery, R. (2015). Revisiting the pedagogy and theory corral: Creative writing pedagogy teachers' conceptions of pedagogic identity. New Writing, 12(2), 205-215.

Marton, F. (1981). Phenomenography - Describing conceptions of the world around us. Instructional Science, 10, 177-200.

Marton, F (2015). Necessary conditions of learning. New York, N Y: Routledge.

Marton, F. \&. Booth, S. (2000). Om lärande. Lund: Studentlitteratur.

Marton, F. \& Pang, M. F. (2013). Meanings are acquired from experiencing differences against a background of sameness, rather than from experiencing sameness against a background of difference: Putting a conjecture to the test by embedding it in a pedagogical tool. Frontline Learning Research, 1(1), 24-41.

Marton, F. \& Runesson, U. (2015). The idea and practice of the Learning Study. I K. Wood \& S. V. Sithamparam (Red.), Realising learning. teachers' professional development through lesson and learning study (s. 103-121). New York och London: Routledge.

Marton, F. \& Säljö, R. (1976). On qualitative differences in learning: Outcome and process. British Journal of Educational Psychology, 46, 4-11.

Marton, F. \& Tsui, A. (Red.) (2004). Classroom discourse and the space of learning. New York: Routledge.

Martre, S. (2013). Elevteksten som vegvisar til tillpasse opplaering. In R. Karlsdottir \& I. H. Lysø (Red.), Laering, Utvikling, Laeringsmiljø: en Innføring i Pedagogisk Psykologi (s. 79-102). Oslo: Akademika. 
Mason, J. (2011). Explicit and implicit pedagogy: variation theory as a case study. I C. Smith (Red.), Proceedings of the British Society for Research into Learning Mathematics, 31(3), 107-112.

McCutchen, D. (2006). cognitive factors in the development of children's writing. I C. MacArthur \& S. Graham (Red.), Handbook of writing research (s. 115-130). New York, N Y: The Guilford Press.

McKeough, A. (1984, 23-27 april). Developmental stages in children's narrative composition. Paper presenterat på the Annual Meeting of the American Educational Research Association $\left(68^{\text {th }}\right)$. New Orleans, LA: USA.

McKeough, A. M. (1987, 12-16 juli). Stages in story telling: A neo-piagetian analysis. Paper presenterat på the Biennial Meeting of the Society for the Study of Behavioral Development. Tokyo: Japan.

McKeough, A. \& Genereux, R. (2003). Transformation in Narrative Thought During Adolescence: The Structure and Content of Story Composition. Journal of Educational Psychology, 95(3), 537-552.

Montague, M. \& Leavell, A. G. (1994). Improving the Narrative Writing of Students with Learning Disabilities. Remedial and Special Education (RASE), 15(1), 21-33.

Morris, A. K. \& Hiebert, J. (2011). Creating Shared Instructional Products: An Alternative Approach to Improving Teaching. Educational Researcher, 40(1), 5-14.

Mårtensson, P. (2015). Att få syn på avgörande skillnader. Lärares kunskap om lärandeobjektet. (Doktorsavhandling) Jönköping: School of Education and Communication, Jönköping University.

Norberg Brorsson, B. (2007). Man liksom bara skriver: Skrivande och skrivkontexter $i$ grundskolans år 7 och 8. (Doktorsavhandling). Örebro: Mälardalens högskola.

Nordlund, A. (2016). Berättarteknik i elevberättelser i tidiga skolår. Forskning om undervisning och lärande, 2(4), 46-67.

Nyberg, G. (2014). Ways of knowing in ways of moving: A study of the meaning of capability to move. (Doktorsavhandling). Stockholm: Stockholms universitet.

Olin-Scheller, C. \& Wikström, P. Leterary prosumers: Young people's reading and writing. Education Inquiry, 1(1), 41-56.

Ong, W. J. (1982). Muntlig och skriftlig kultur. Teknologisering av ordet. Göteborg: Bokförlaget Anthropos.

Pang. M. F. \& Ki, W. W. (2016). Revisiting the Idea of "Critical Aspects". Scandinavian Journal of Educational Research, 60(3), 323-336.

Pang, M.F. \& Ling, L.M. (2012). Learning study: helping teachers to use theory, develop professionally, and produce new knowledge to be shared. Instructional Science, 40, 589-606.

Pang, M. F. \& Marton, F. (2003). Beyond "lesson study": Comparing two ways of facilitating the grasp of some economic concepts. Instructional Science, 31(3), 175194.

Polanyi, M. (1962a). Tacit knowledge. Terry lectures, Yale.

Polanyi, M. (1962b). Skills and connoisseurship. Terry lectures, Yale. 
Pring, R. (2006). Philosophy of Educational Research (Andra upplagan). London: Continuum.

Prior, P. (2006). A Sociocultural Theory of Writing. I C. MacArthur \& S. Graham (Red.), Handbook of Writing Research (s.54-66). New York: The Guilford Press.

Pritchard, R. \& Honeycutt, R. (2006). The Process Approach to writing Instruction. I C. MacArthur \& S. Graham (Red.), Handbook of Writing Research (s. 275-290). New York: The Guilford Press.

Propp, V. (1928/2015). Morphology of the Folktale. Mansfield centre, CT: Martino Publishing.

Riley, J. \& Reedy, D. (2005). Developing young children's thinking through learning to write argument. Journal of Early Childhood Literacy, 5 (29), 29-50.

Runesson, U. (2017). Variationsteori som redskap för att analysera lärande och designa undervisning. . I: I. Carlgren (Red.), Undervisningsutvecklande forskning - exemplet Learning study (s. 45- 60). Malmö: Gleerups.

Runesson, U. \& Gustavsson, G. (2012). Sharing and developing knowledge products from Learning Study. International Journal for Lesson and Learning Studies, $1(3), 245-260$.

Ryle, Gilbert (1963), Knowing how and knowing that. I Ryle, G (Red.), The concept of mind (s. 26-60). London: Penguin.

Rönnerman, K. (2005). Participant knowledge and the meeting of practitioners and researchers. Pedagogy, Culture and Society, 13(3), 291-312.

Rönnerman, K. (2011). Aktionsforskning - kunskapsproduktion i praktiken. Forskning om undervisning och lärande, 5, 51-62.

Saddler, B. \& Asaro. K. (2007). Increasing Story Quality Through Planning and Revising: Effects on Young Writers with Learning Disabilities. Learning Disability Quarterly, 30(4), 223-234.

Sanders, T. J. M. \& Schilperoord, J. (2006). Text Structure as a Windows of the cognition of writing: How Text Analysis Provides Insights in Writing Products and Writing Processes. I C. A. MacArthur, S. Graham \& J. Fitzgerald (Red.), Handbook of Writing Research (s. 386-402). New York: The Guilford Press.

Scardamalia, M. \& Bereiter, C. (1987). Knowledge telling and knowledge transforming in written composition. I S. Rosenberg, Advances in applied psycholinguistics, Volume 2: Reading, writing, and language learning (s. 142-175). New York, NY, US: Cambridge University Press.

Schön, D. A. (1983). The reflective practioner. How professionals think in action. New York: Basic Books.

Scribner, S. \& Cole, M. (1983). The Psychology of Literacy. Cambridge: Harvard University Press.

Shavelson, R. J., Phillips. D.C., Towne, L. \& Feuer, M.T. (2003). On the science of education design studies. Educational Researcher, 32(1), 25-28.

Shulman, L. S. (1986). Those Who Understand: Knowledge Growth in Teaching, Educational Researcher, 15 (2), 4-14. 
Shulman, L. S. (1987). Knowledge and Teaching: Foundations of the New Reform, Harvard Educational Review, 57 (1), 1-22.

Skolverket. (2011). Läroplan för grundskolan, förskoleklassen och fritidshemmet 2011. Stockholm: Skolverket.

Skolverket. (2013). Bedömarträning i svenska och svenska som andraspråk. Stockholm: Skolverket.

Somekh, B. \& Zeichner, K. (2009). Action research for educational reform: remodelling action research theories and practices in local contexts. Educational Action Research, $17(1), 5-21$.

SOU 2008:7. Världsklass! Ȧtgärdsplan för den kliniska forskningen. Delbetänkande av utredningen av den kliniska forskningen. Stockholm: Fritzes Offentliga Publikationer.

Stake, R. (2010). Qualitative Research. Studying how things work. The Guilford Press, New York.

Stein, N. L. (1982). The definition of a story. Journal of Pragmatics, 6, 487-507.

Stein, N. L. \& Glenn, C. G. (1979). An analysis of story comprehension in elementary school children: A test of a schema. In R. Freedle (Red.), Discourse processing: Multidisciplinary perspectives (No. 1.2) (s. 2-68). Norwood, N.J.: Ablex, Inc.

Stenhouse, L. (1981). What counts as research? British Journal of Educational Studies 2, 29(2), 103-114.

Stewart, W. (2015, 22 april). Leave research to the academics, John Hattie tells teachers. TES. Nerladdad 2017-11-10. https://www.tes.com/news/school-news/breaking-news/leave-research-academics-john-hattie-tells-teachers

Stiles, W. B. (2009). Logical operations in theory-building case studies Pragmatic Case Studies in Psychotherapy, 5(3), 9-22.

Sädbom Florin, R. (2015). I det didaktiska spänningsfältet mellan styrning och elevers lärande: En studie av lärares tal om och iscensättning av kursplanemål $i$ en måloch resultatstyrd skola. (Doktorsavhandling). Jönköping: Högskolan för lärande och kommunikation, Jönköping.

Temizkan, M. (2011). The Effect of Creative Writing Activities on the Story Writing Skill. Educational Sciences: Theory \& Practice, 11(1), 933-939.

Thorsten, A. (2014). Perspektiv och problemlösning i berättelseskrivande. Vad elever behöver lära sig och hur det kan synliggöras $i$ undervisningen. (Licentiatuppsats). Jönköping: Jönköping University.

Thorsten, A. (accepterad). How to compose a narrative - students' approaches and pedagogical implications. Writing and Pedagogy, publiceras hösten 2018.

Thorsten, A. (2015). How teachers' practice knowledge is used and challenged in a Learning Study using Variation Theory as a tool. International Journal of Lesson and Learning Studies. 4 (3), 274-287.

Thorsten, A. (2017). Generating knowledge in a Learning Study - from the perspective of a teacher researcher. Educational Action Research, 25(1), 140-154. 
Thygesen, R. \& Berge, K. L. (2015). Skrivande som grundläggande färdighet: förståelse, bedömning och undervisning. I G. Skar \& M. Tengberg (Red.), Bedömning $i$ svenskämnet årskurs 7-9 (s. 63-86). Stockholm: Natur och Kultur.

Vetenskapsrådet. (2011). God forskningssed. Stockholm: Vetenskapsrådet.

Vikström, A., Kullberg, A., \& Runesson Kempe, U. (2017, 29 augusti - 2 september). Can public knowledge be created through practitioner research? - Learning studies and variation theory as mechanisms and strategies behind knowledge production in teachers' research. Paper presenterat på: 17th Biennial EARLI 2017, Tampere, Finland.

Vygotskij, L. (1950/ 1995). Fantasi och kreativitet i barndomen. Göteborg: Daidalos.

Vygotskij, L. (1934/2001). Tänkande och språk. Lund: Daidalos AB.

Waitman, G. R. \& Plucker, J. A. (2009). Teaching Writing by Demythologizing Creativity. I S. B. Kaufman (Red.), The psychology of Creative Writing (s. 287-315). New York: Cambridge University Press.

Winzell, H. (2016). Svensklärares skrivdidaktiska kunskapsbildning / Blivande och tidigt verksamma gymnasielärare i svenska talar om skrivundervisning. (Licentiatuppsats). Linköping: Linköpings universitet.

Yassin Falk, D. (2017). Skrivundervisning I grundskolans årskurs 3. (Doktorsavhandling). Örebro: Örebro University. 


\section{Bilaga 1}

Bild som användes vid kartläggningen och vid förbedömningen.

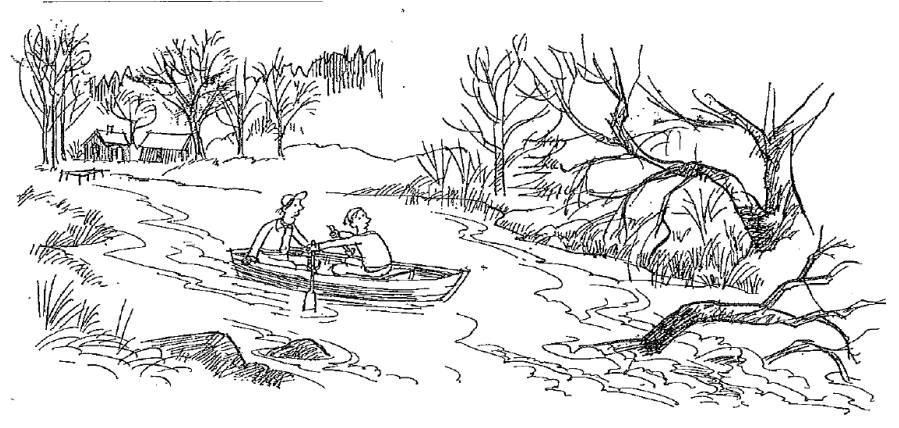




\section{Bilaga 2}

Bild som användes vid efterbedömningen.

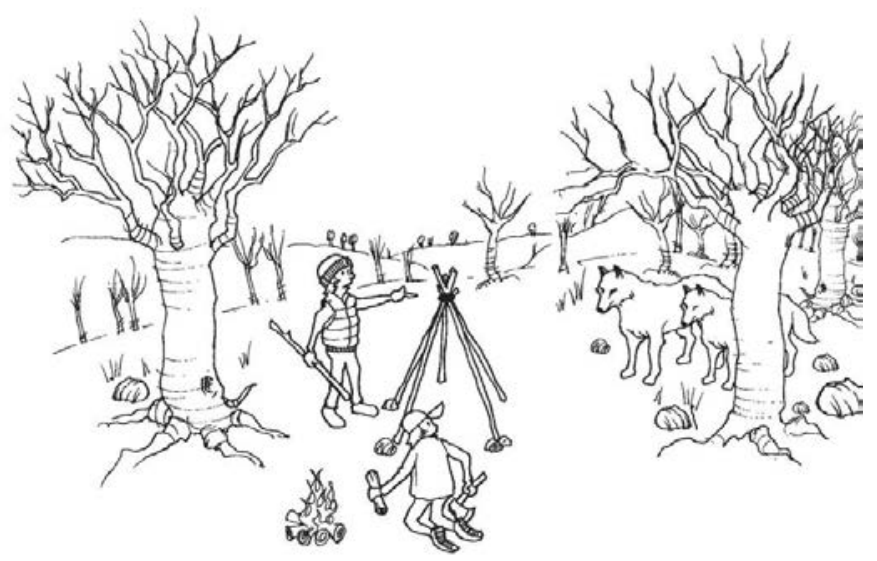




\section{Publikationer}

Publikationerna kopplade till denna avhandling har tagits bort på grund av upphovsrättsliga skäl. För mer information om dem gå till:

http://urn.kb.se/resolve?urn=urn:nbn:se:liu:diva-149806 


\section{LINKÖPING STUDIES IN BEHAVIOURAL SCIENCE}

183. NYLANDER, ERIK. Skolning i jazz. Värde, selektion och studiekarriär vid folkhögskolornas musiklinjer. 2014. ISBN: 978-91-7519-347-2

184. GRADIN FRANZÈN, ANNA. Disciplining freedom: Treatment dilemmas and subjectivity at a detention home for young men. 2014. ISBN: 978-91-7519-344-1

185. ENGSTRÖM, ANNIKA. Lärande samspel för effektivitet. En studie av arbetsgrupper i ett mindre industriföretag. 2014. ISBN:978-91-7519-345-8

186. ELWÉR, ÅSA. Early Predictors of Reading Comprehension Difficulties. 2014. ISBN: 978-91-7519$281-9$

187. LARSON, NICLAS. Matematikämnet och stadiebytet mellan grundskolan och gymnasieskolan. En enkät- och klassrumsstudie. 2014. ISBN: 978-91-7519-196-6

188. LY, HOA. Use of a Smartphone Application in the Treatment of Depression - The New Wave of Digital Tools for Psychological Treatment. 2015. ISBN: 978-91-7519-136-2

189. HANSSON, PER-OLOF. New ways of learning. Participatory action research and Kenyan runners' appropriation of smartphones to improve their daily lives and participation in m-learning. 2015. ISBN: 978-91-7519-124-9

190. BOLLDÈN, KARIN. Online teaching practices. Sociomaterial matters in higher education settings. 2015. ISBN: 978-91-7519-123-2

191. MALMQUIST, ANNA. Pride and Prejudice. Lesbian families in contemporary Sweden. 2015. ISBN: 978-91-7519-087-7

192. AVBY, GUNILLA. Evidence in Practice. On Knowledge Use and Learning in Social Work. 2015. ISBN: 978-91-74519-088-4

193. FORSBERG, CAMILLA. Students’ Perspectives on Bullying. 2016. ISBN: 978-91-7685-874-5

194. MUHRMAN, KAROLINA. Inget klöver utan matematik. En studie av matematik i yrkesutbildning och yrkesliv. 2016. ISBN: 978-91-7685-851-6

195. SKAGERLUND, KENNY. Magnitude Processing in Developmental Dyscalculia. A Heterogeneous learning disability with different cognitive profiles. 2016. ISBN: 978-91-7685$831-8$

196. EKEBLAD, ANNIKA. A Randomized Trial of Interpersonal Psychotherapy and Cognitive Behavioral Therapy for Major Depressive Disorder - Predictors of process and outcome. 2016. ISBN: 978-91-7685-803-5

197. MÅNSSON, KRISTOFFER N.T. Restructuring the Socially Anxious Brain. Using magnetic resonance imaging to advance our understanding of effective cognitive behaviour therapy for social anxiety disorder. 2016. ISBN: 978-91-7685-688-8

198. SILFVERNAGEL, KRISTIN. Individually tailored internet-based cognitive behavioural therapy for adolescents, young adults and older adults with anxiety. 2017. ISBN: 978-91-7685-566-9

199. ELOFSSON, JESSICA. Children's early mathematics learning and development. Number game interventions and number line estimations. 2017. ISBN: 978-91-7685-517-1

200. ÅHLFELDT, EMANUEL. Hållbart utvecklingsarbete i vård och omsorg. Ett institutionellt perspektiv på projekt i en professionell och byråkratisk kontext. 2017. ISBN: 978-91-7685-445-7 
201. VERNMARK, KRISTOFER. Therapeutic alliance and different treatment formats when delivering internet-based CBT for depression. 2017.

ISBN: 978-91-7685-436-5

202. FRANKL, MY. Psychotherapy for Substance Use Disorder - the importance of affects. 2017. ISBN: 978-91-7685-429-7

203. ABDULLA, AFRAH. Readiness or resistance? - Newly arrived adult migrants' experiences, meaning making, and learning in Sweden. 2017. ISBN: 978-91-7685-428-0

204. OLSSON, LINDA. "Count on me!". Mathematical development, developmental dyscalculia and computer-based intervention. 2018. ISBN: 978-91-7685-409-9

205. COLLIANDER, HELENA, Being and Becoming a Teacher in Initial Literacy and Second Language Education for Adults. 2018. ISBN: 978-91-7685-304-7

206. TOPOOCO, NAIRA. Blended Cognitive Behavior Therapy. Efficacy and Acceptability for Treating Depression in the Adult and Adolescent Population. 2018. ISBN: 978-91-7685-297-2

207. SOLÍS MARCOS, IGNACIO. Challenges in Partially Automated Driving: A Human Factors Perspective. 2018. ISBN: 978-91-7685-296-5 